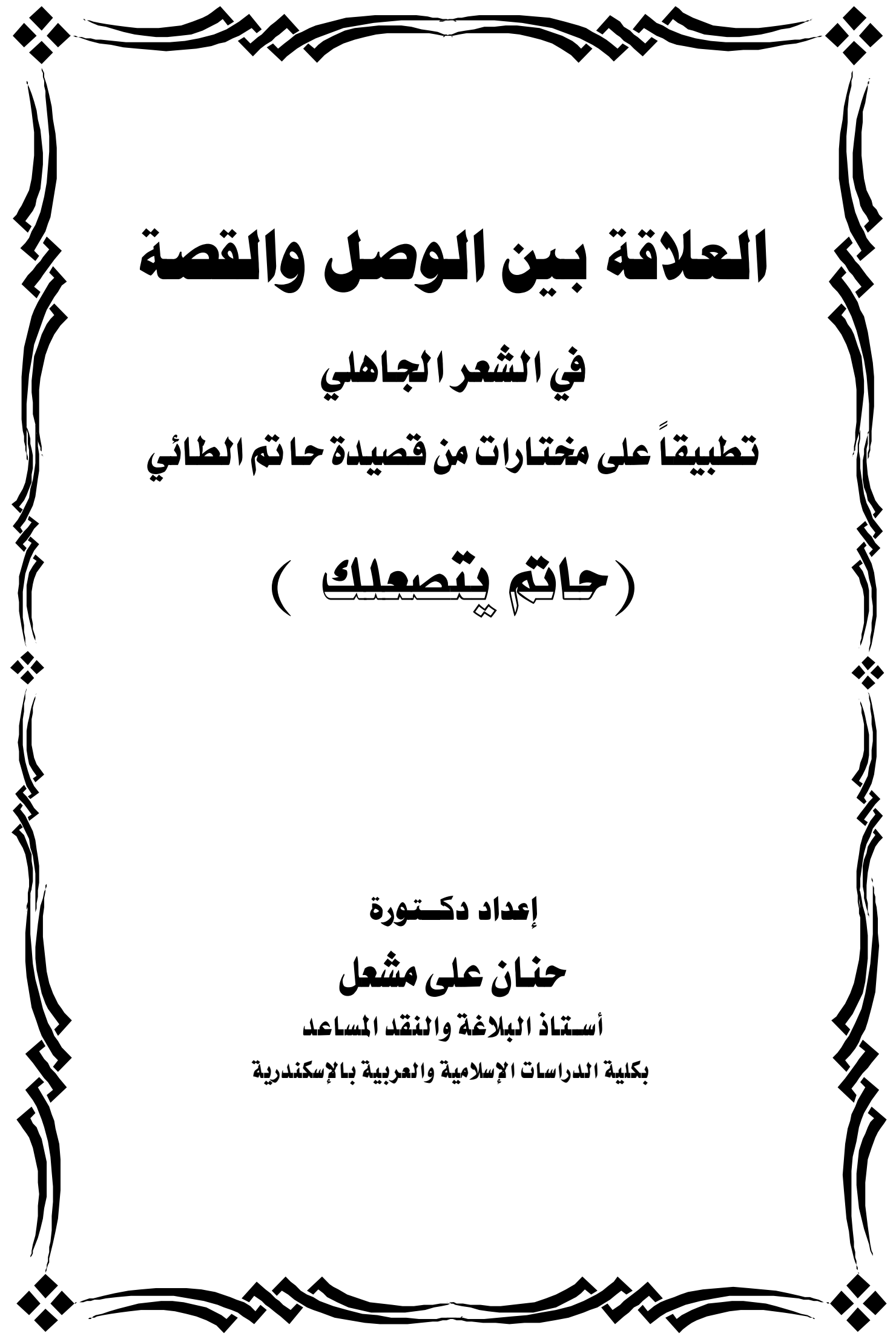




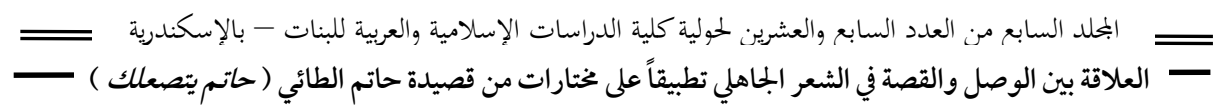

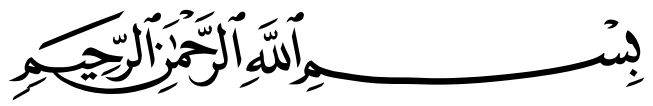

المقدمة

الحمد لله الذي هيأ قلوب عباده لاستقبال فيض هداه، وألقى على بصائرهم من أنوار بيانه ما جلي لهم حقائق تنزيله، وأفاض على عقولهم من حكمته ما اهتدوا به إلى ما خفي من أسراره، ومس أذواقهم بعذب كلامه، فاستشرفت لطائفه

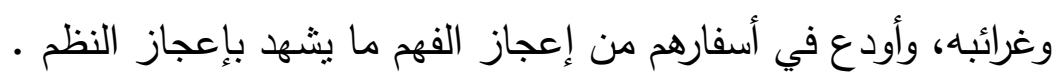

\section{ويعد :}

فلقد أثارني على وجه الخصوص وبدقة بالغة سر العلاقة بين باب غاية في

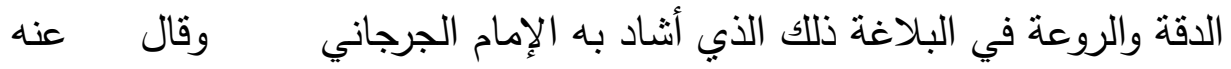
بأن من تحققت لديه المعرفة به وفهمه فقد تحقق لديه العلم بالبلاغة كلها ألا وهو

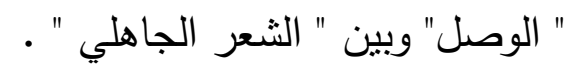

أو بشكل آخر ما سر " كثرة الوصل في الثعر الجاهلي " على وجه الخصوص وبخاصة أثناء إعدادي لرسالة الماجستير التي كانت تحت عنوان (دراسة بلاغية في ديوان الصعاليك بين النظرية والتطبيق ) وكانت الدراسة تشمل الثعراء الجاهليين ( الثنفرى - عروة بن الورد- السليك بن السلكه • تأبط شراً )

وقد وضعت توصيات ومقترحات كثثرة منها ضرورة التتقبب عن الثواهد البلاغية المختلفة وكذا الظواهر وإيجاد تفسير لها نحو " التراسل والرمز وكثرة الوصل في الشعر الجاهلي ولاسيما شعر الشعراء الصعاليك فقد عاودت القراءة والبحث حتى تبلورت الفكرة في ذهني فأخذت في القراءة الجادة والتحليل حتى توصلت إلى نتائج هامة سأقوم بطرحها بالتقصيل في موطنها 
—— = $=$

ومن ثم تناولت البحث على النحو التالي :

\section{المبحث الأول : ويشتمل على ما يلي :}

أ- نبذة عن أهم خصائص الشعر الجاهلي •

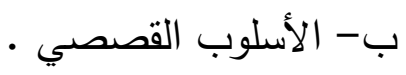

ح- سر العلاقة بين الوصل والثعر الجاهلي •

د- نص القصيدة - نزجمة عن الثاعر

\section{المبحث الثاني : ويشتمل على ما يلي :}

أ- التحليل البلاغي للقصيدة .

$$
\text { ب- الخاتمة . }
$$

ج- المصادر والمراجع • 


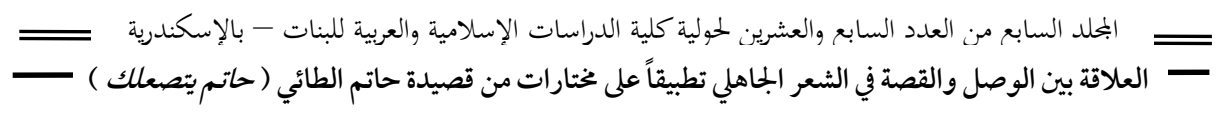

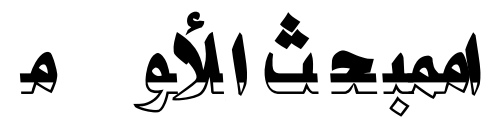

\section{وهشتمل على ما بلي :}

أ- بلذة عن أهم خصسائص الشهر الجهاهلي .

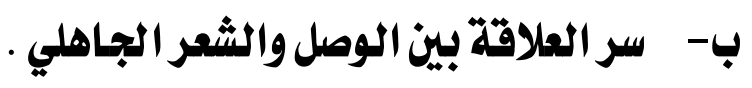

( الأسلوب الثصصيي )

ح- نص القصيلة - ترجمة عن الشاعر . 


\section{أ- بذة موجزة عز أهم خصائم الشمر الجاهلي}

لقد امتاز الثعر الجاهلي ببعض الخصائص التي ميزته عن غيره من العصور الأخرى، كصعوبة الألفاظ وغرابتها في كثير من شعرهم، وكالأسلوب لبهن القصصي الذي يبدو في بعض شعرهم ، وكذا في انفراده ببعض الموضوعات والتصوير واختلاف مستوى الألفاظ وغرابتها .

\section{ب- الأسلوب القصصي :}

يثيع بين الباحثين أن أول من استعمل أسلوب القصة " امرؤ القيس" في

لاميته التي يصور فيها قصته مع عشيقته، والتي يقول فيها من قصته معها :

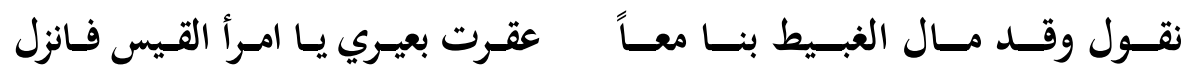

ويرى بعض الباحثين الذين تحدثوا عن " عمر بن أبى ربيعة " أنه خير من

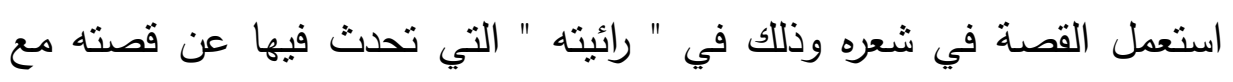
العشيقة التي طلع عليه الصباح عندها فدهثت، ثم استعانت بأختيها، ثم أخفينه بينهن حتى خرجن به من الحي، فكن كالمجن له، كما قال :

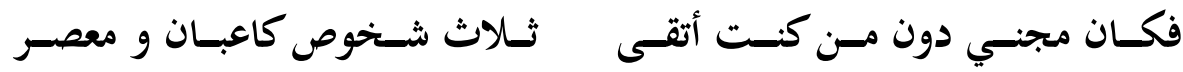
والواقع أن الدارس لثعر الصعاليك لا يشك في أن الذين أسسوا للقصة في الثعر العربي، بل والذين وصلوا إلى مستوى القصة الثعرية الكاملة بمفهومها الفني في شعرهم، "هم الصعاليك"، وأن هذا المنهج لو وجد من الشعراء من تابعه ودئ لكان للقصة في الثعر العربي شأن غير ما كانت عليه " ('). " ونضرب مثالاً للمستوى الذي وصلت إليه القصة في شعر الصعاليك، بقصة " قيس بن منقذ" المعروف بابن الحدادية مع ابنة عمه نعم بنت ذؤيب كما

(1) السكري - ديوان الهذليين - الجزء الثاني، مطبعة دار الكتب المصرية بوه ام ص (ro ) . ( V 1 - 


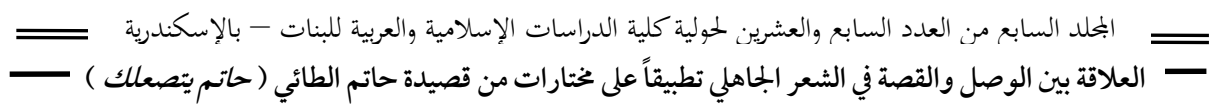

سجلها في شعره، ولكننا لكي نعلم فضله على امرئ القيس في هذا المجال، وكذلك سبقه وفضله على " عمر بن أبى ربيعة " نقول أن قصني ( امرئ القيس وعمر ابن أبى ربيعة ) المشار إليهما، لا بمثنان قصة فنية، وإنما يمثلان موقفاً أو مشهداً من قصة، وإن كان ابن أبى ربيعة أقرب إلى القصة من مشهد أمرئ

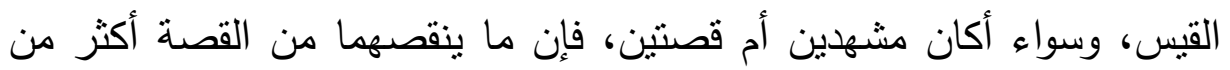
هذا، وهو من النواحي الفنية المعروفة في القصة " ('). أما قصة " قيس بن منقذ " فقد راعى فيها كل الخطوط الأساسية للقصة الفنية من نواحيها النفسية، ومن جوانب الوصف ومن الحوار، ومن جو القصة وروحها، وقد سجل قصته هذه في قصيدة طويلة نجنزئ منها هذه الأبيات التي تمس صلب القصة، لنبين منها إلى أي حد بلغ شعر الصعاليك الجاهليين بالقصة " (r) (ب)

وظروف القصة أن قيساً بحكى ما دار بينه وبينها من حوار وأحداث

ووداع في ليلة سفره، واصفاً استعداد الحداة ورفقاءه في القافلة وإعدادهم للرحيل :

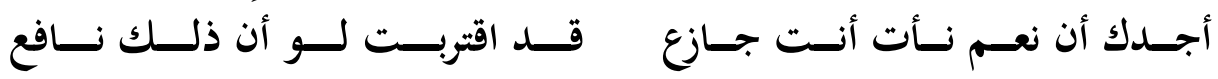

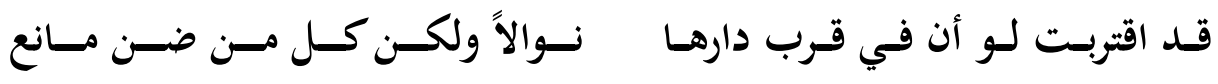

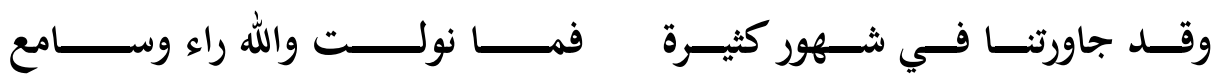

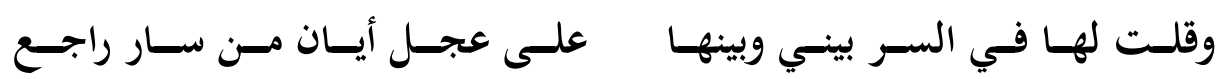

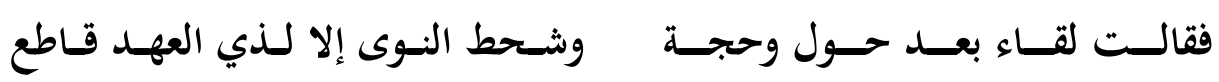
وقد يلتقي بعـد الشـتات أولو النوى ويسـترجع الحسي الســحاب اللوامـع

(1) الخضـري / مهذب الأغـاني، الجـزء الأول، مطبعـة دار الكتب المصـرية - بـدون ص (1) $\cdot(1 \cdot v)$

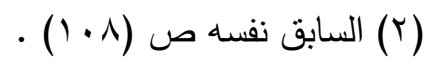




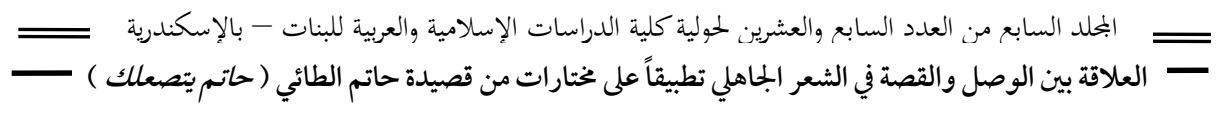

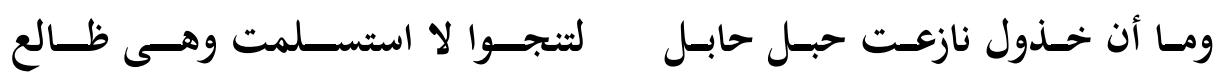

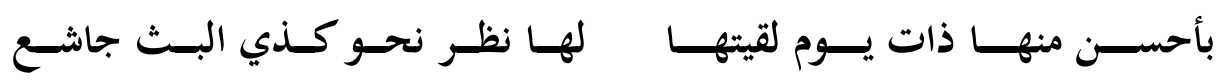

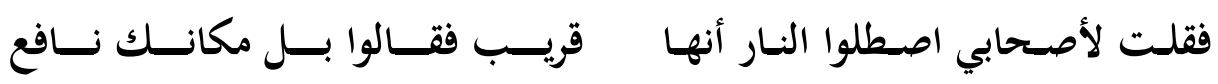

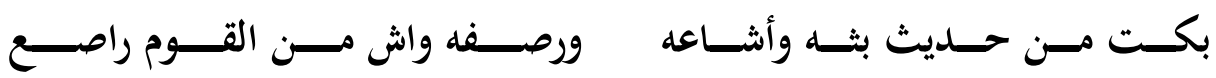

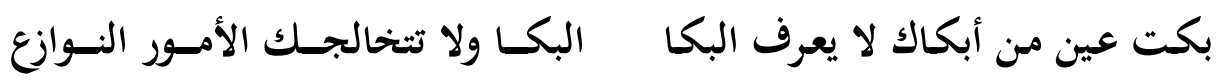

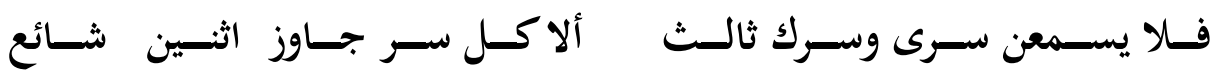
وكيـف يشـيع السـر منسى ودونسه حجـاب ومسن دون الحجـاب الأضـالع

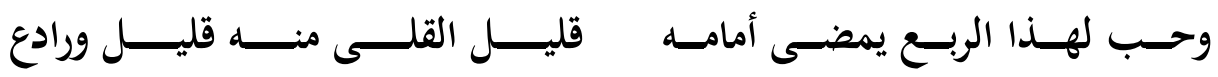

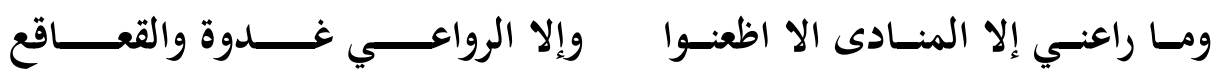

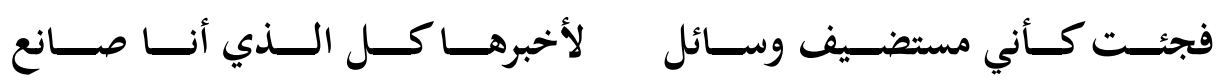

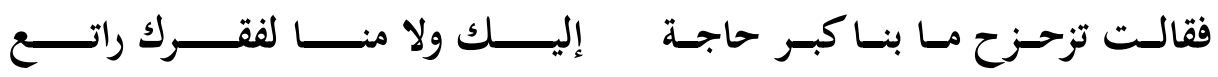
فمازلـت تحست السـتر حتسى كـأنني مسن الحـرذ وطمـرين في البحر كسارع

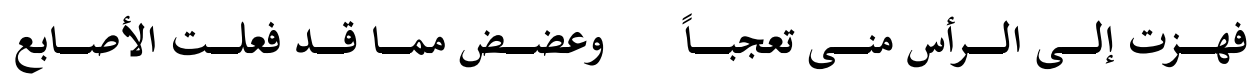

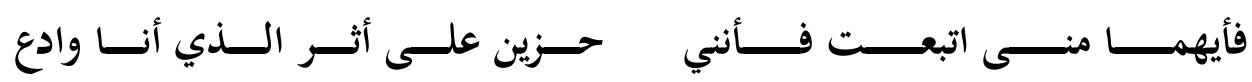

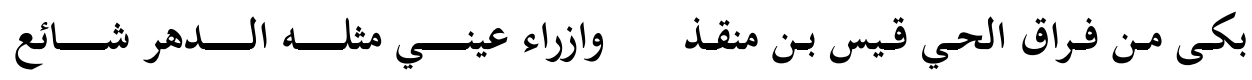

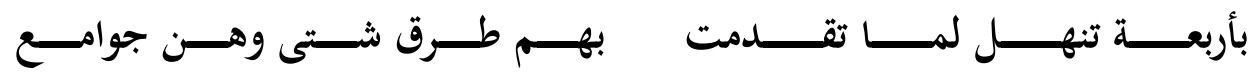

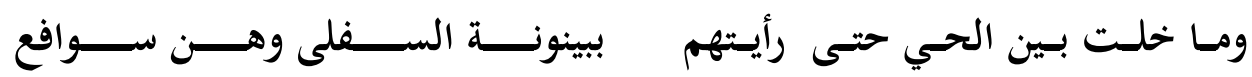

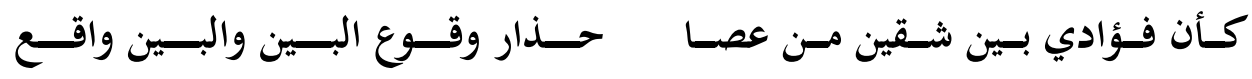

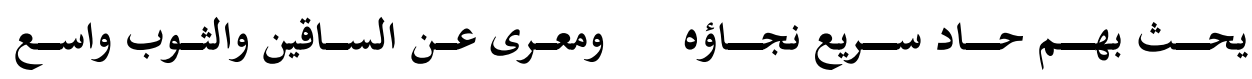

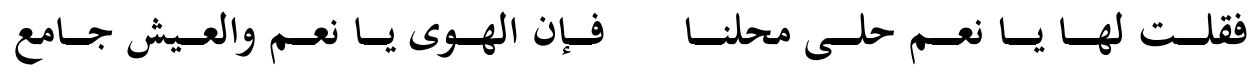




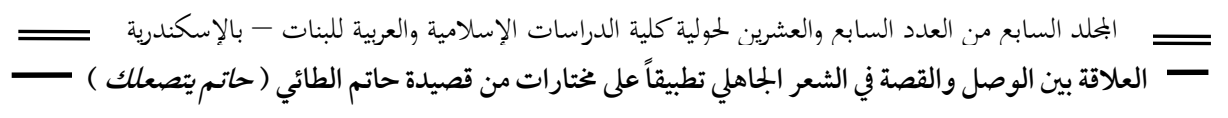

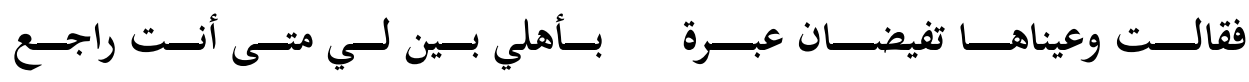

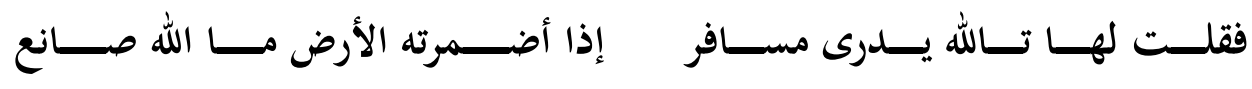
فشــت على فيها اللثـام وأعرضـت وأمعـن بالكحــل السـحيق المــدامع فقد مهذ في الأبيات الأولى بوصف بطلة القصة، وأخلاقها، والجو الذي

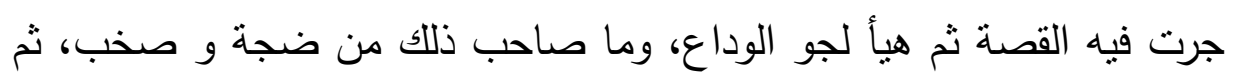

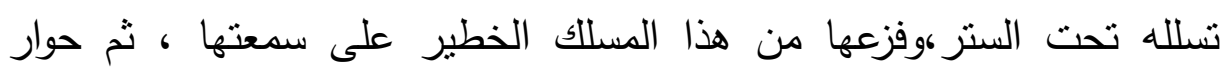

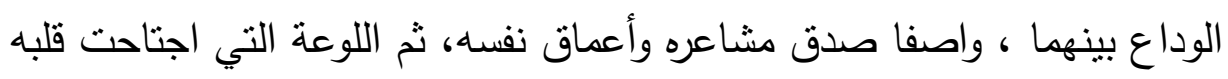

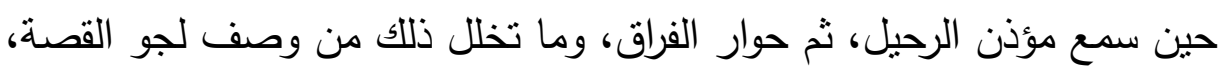

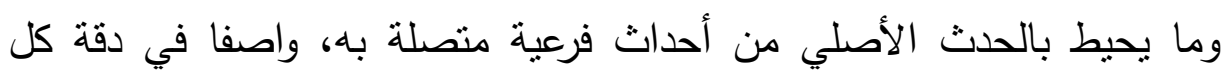

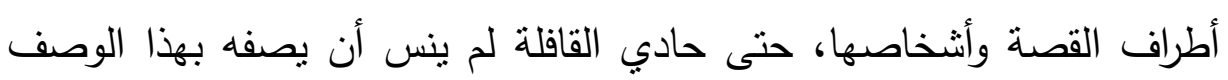

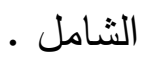

بحسث بهــم حساد ســـيع نجــاؤه ومعسرى عـن السـاقين والثـوب واسـع

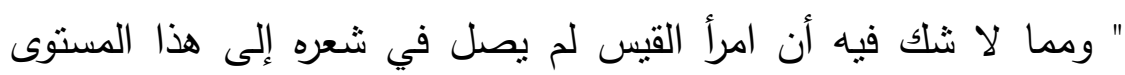

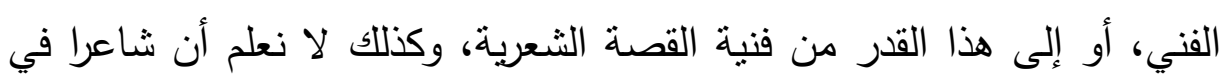

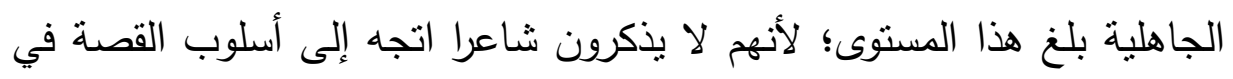

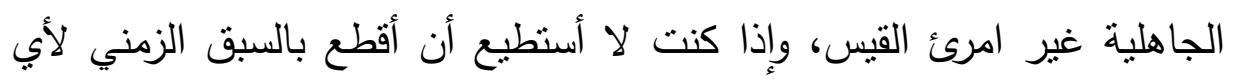

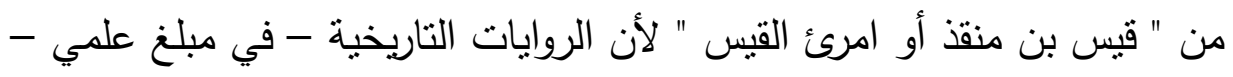

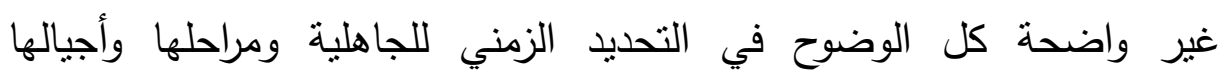

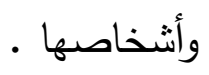

أقول: إذا كنت لا أستطيع ذلك، فإني أستطيع أن أقول: إن امرأ القيس

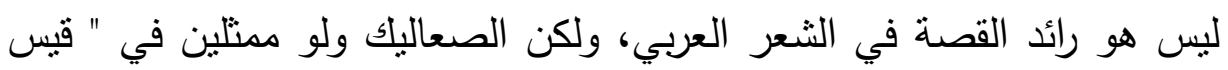




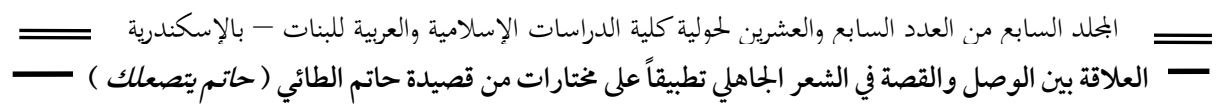

بن منقة" هم رواد القصة بمعناها الفني كما رأينا في قصيدة قيس السابقة الذكر

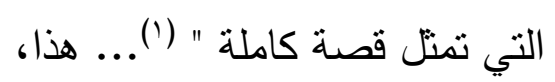

وفى رأيي: إنه مهما حاول ناقد قصصي أن يقلل من كما لها الفني، فلابد

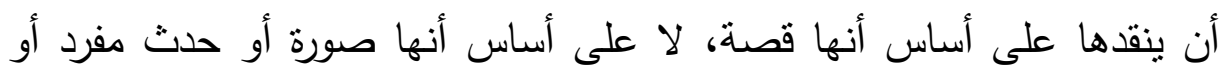
مجموعة مشاعر ، أو أي شئ يشكك في مبدأ أنها قصة، هذا، والفارق كبير بين أن بنقل شيء على أساس أنه قصة، وأن ينقد على أساس عدم الاعتراف بأنه قصة،

" والذي يدلل على أن اتجاه صعاليك الجاهلية للقصة كان اتجاهاً أصيلاً بل ومقصوداً أننا نجدهم لم يكتفوا بهذا الوصف الذي يمكن أن يقال عنه أنه انه تصوير لمشهد، يمكن أن نجده في شعر غيرهم كوصف المعارك والرحلات ومتابعة أحداثها ونحو ذلك، بل اتجهوا إلى التخيل في القصة، بذكر أحداث أو قصص متخيلة وذكر الأحداث القصصية بطريق التخيل مهما يكن له من

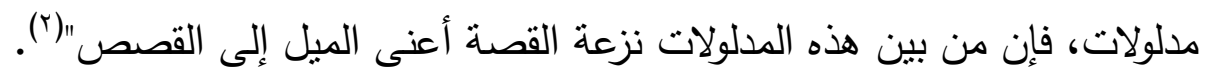

\section{سر العلاقة بيز الوصل والشعر الجاهلي}

لما كان الوصل يتتاسب مع " القصص" - ليس على الإطلاق - لأنه

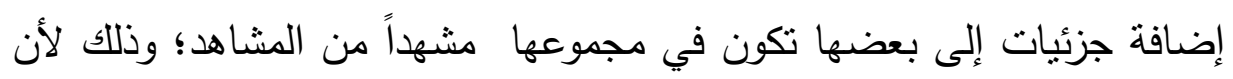
القصيدة تحكى قصة كرم " حاتم الطائي" ولوم امرأتان له بعد فترة من الرقاد على هلى

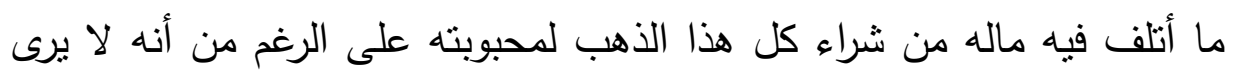
في إتلاف ماله في الحمد غرماً كبيراً . مأه

(1) د/ يوسف خليف - الثـعراء الصعاليك في العصر الجاهلي - ط دار المعارف الطبعة

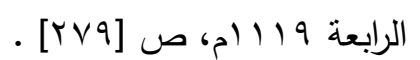

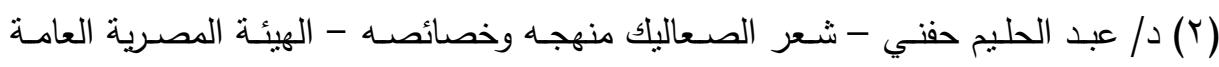

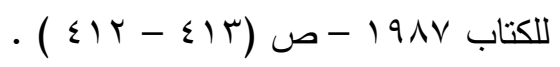




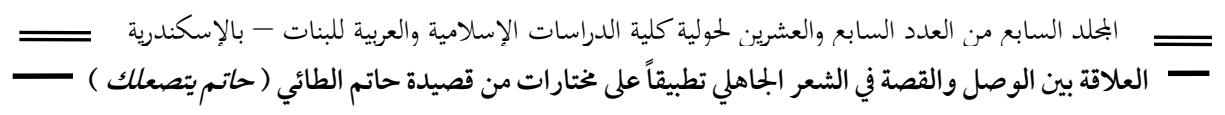

وأجابهما بعد ما طال بهما اللوم والحديث قائلاً كفا كما لوما وعتاباً على ما

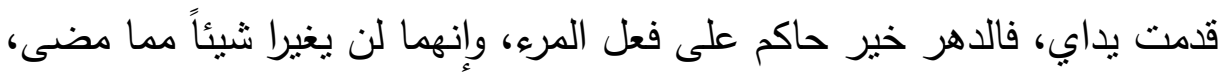
وأنه على ما فات ليس بنادم فالقصيدة تصور مشاهد كثيرة منها مخاطبته لصاحبه وسؤاله له عن بقايا ديار قد اندثرت ولم يتبق من منازلها سوى حفرة كانت تخيط بالخيمة لتمنع عنها السيل ثم العثور بعد ذللك عليها وشراء الذهب لها .... الخ الحديث السابق ثم مشهد المحبوبة وهى تتقلب بين جنبات الفراش، تسمع لحليها ترنماً دلالة على الدعة والسعادة التي عاثها في تلك الديار . لذا في رأيي : - إن لم أكن مبالغة كان ذلك سبباً لكثرة مواضع الوصل وتتوعها في القصيدة، فلقد أبدع فيها " الطائي" على غير مثيل؛ لذا كان منتهى التقرد والإبداع في عرض الصور داخل قصيدته هذه .

أما الفصل فهو " عرض لشيء واحد من زوايا متعددة "؛ مما يجعل (القاص)، وكأنه ثنابت في مكانه، بينما يضيف " الوصل" للصورة أو اللوحة البلاغية " المزيد من النبض والحركة ويسجل الثتتيت من الانفعالات " . 
$=$

\section{الآه نص القصيدة الاله}

\section{الاله حاتم يتصماك لآله}

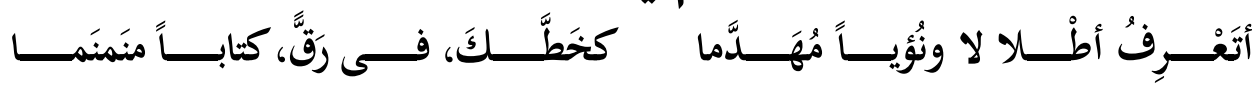

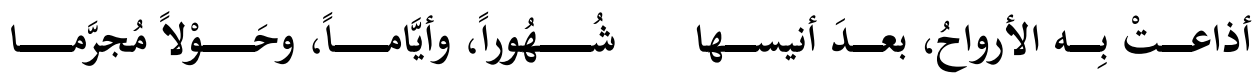

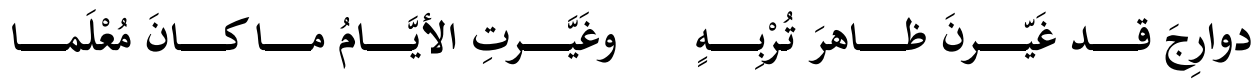

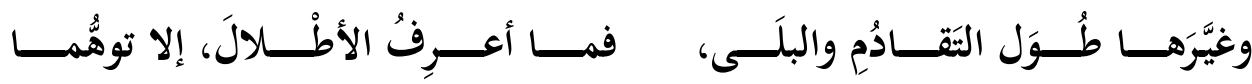

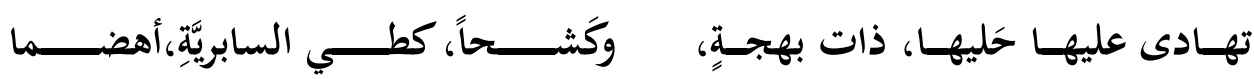

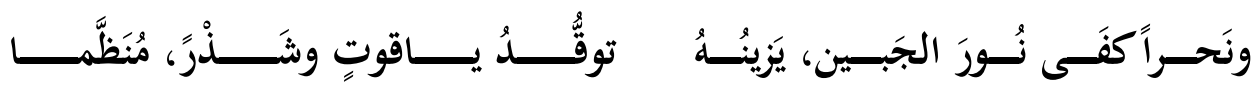

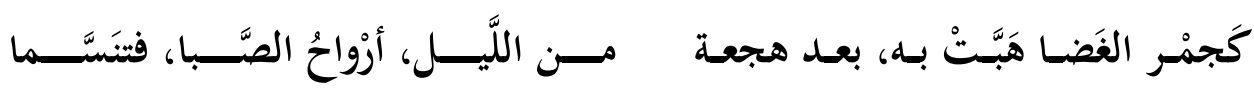

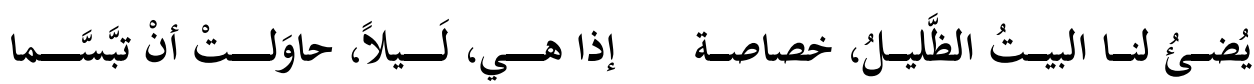

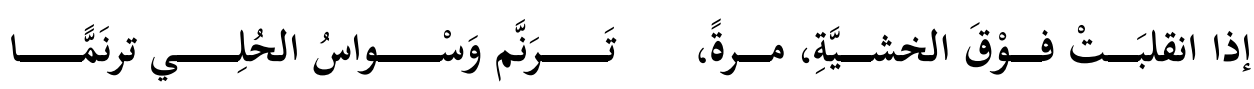

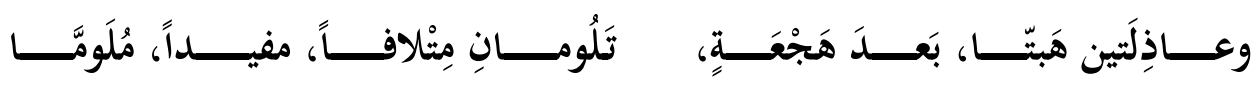

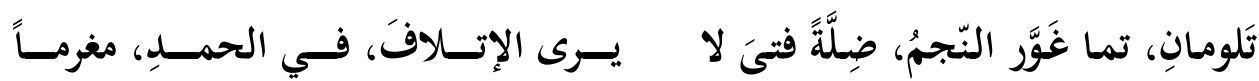

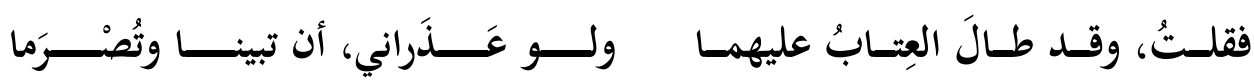

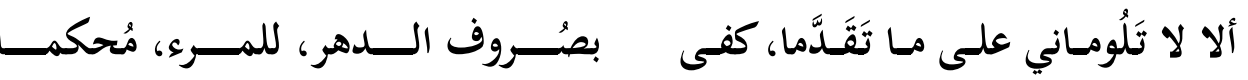

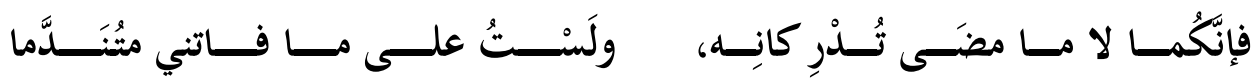

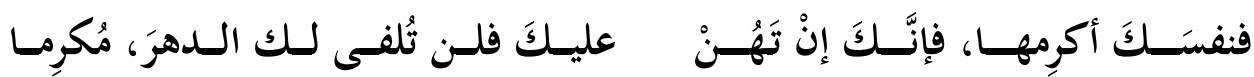

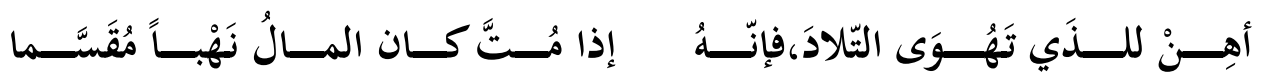

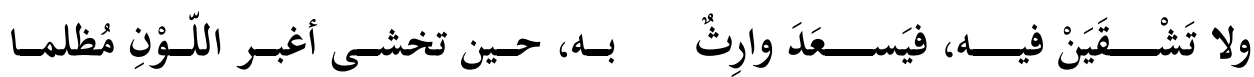

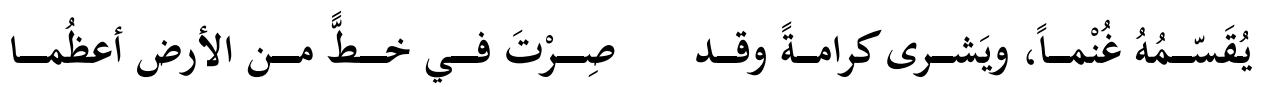




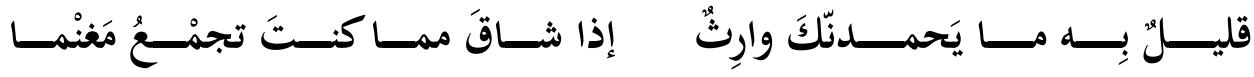

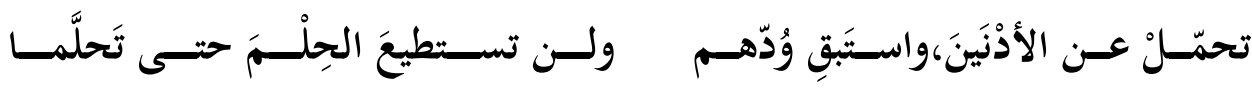

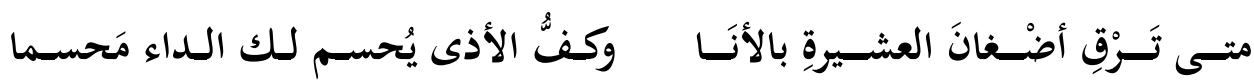

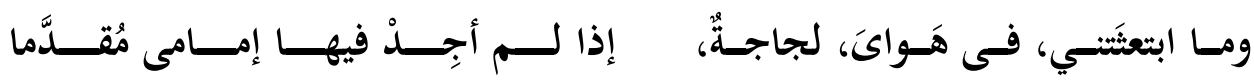

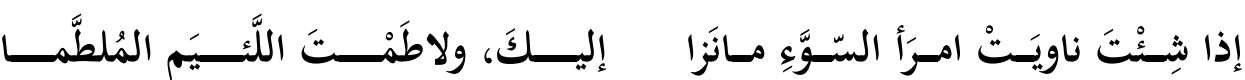

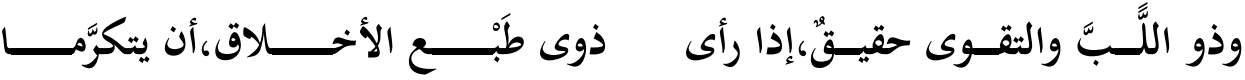

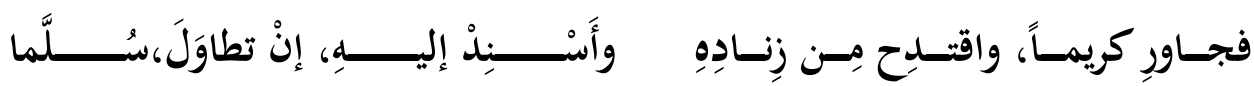

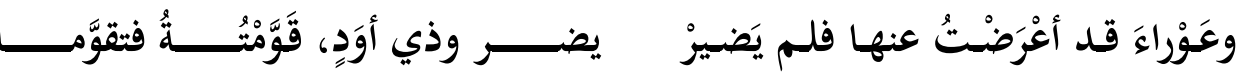

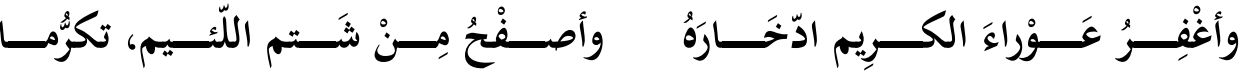

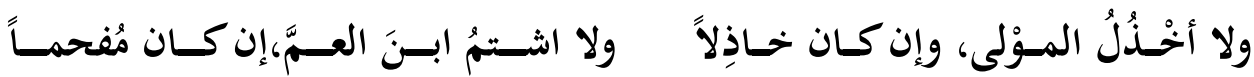

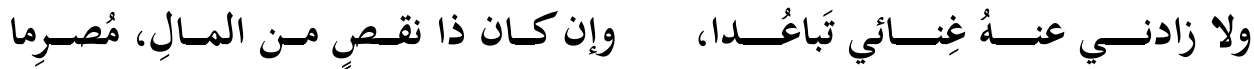

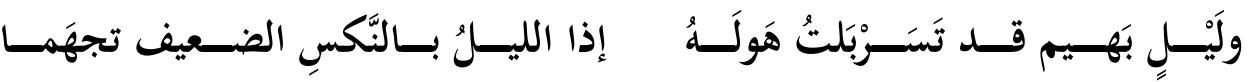

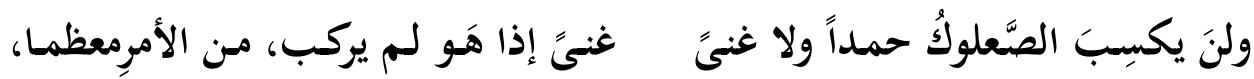

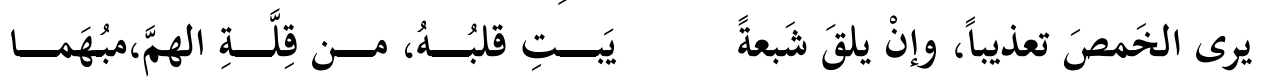

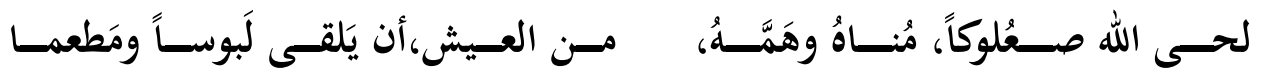

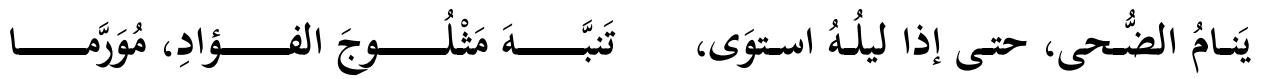

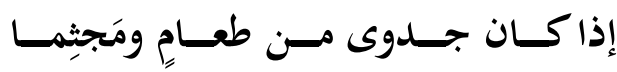
ويمضسى على الأحسداث والــدهُ مقـدِما

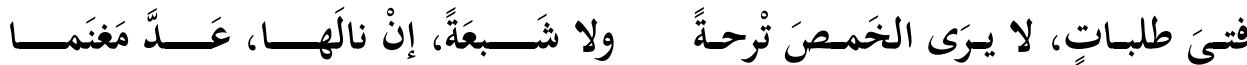

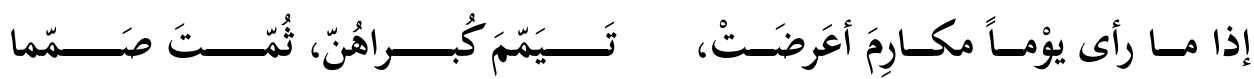

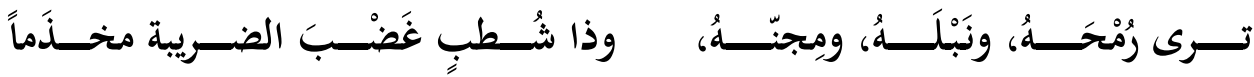

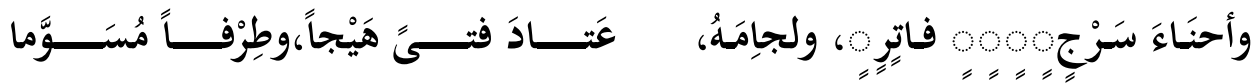




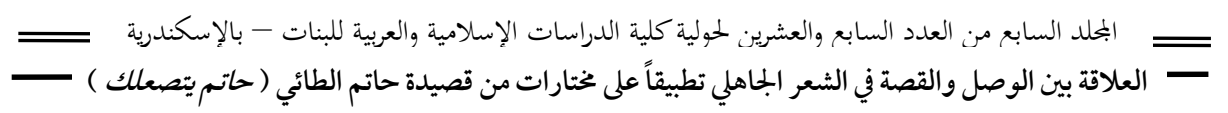

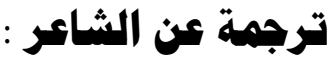

" حاتم الطائي " رجل القيم السامية في مجتمع فسدت فيه القيم؛ القيم الأخلاقية والقيم الاقتصادية والقيم الدينية؛ فأراد أن يمنل لنا نموذجاً يكاد يكون فريداً في الإيثار والكرم والثهامة والتواضع رغم أصالة نفسه وشرق محتده ـ " هو حاتم بن عبد الله بن سعد الطائي، ينسب إلى قبيلة "طئ" وهى من القبائل العربية الثهيرة في الجاهلية، حتى إن لها لغة خاصة بها تسمى لغة طئ عاش في الجاهلية وتوفى قبل بعثة الرسول فئل بفترة قصيرة من الزمن، وتروى الروايات أن

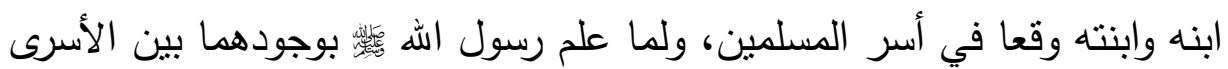

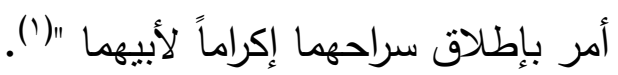

\section{ديوان هاتم :}

خلف حانم الطائي ديواناً صغيراً، ويبدو أنه لم يكن مستغرقاً في الثعر بقدر استغراقه فيما عرف عنه من كرم وإغاثة الملهوف وإجارة المستجير والثفاعة لمن وقع من أهله في أسر أعدائه (؟).

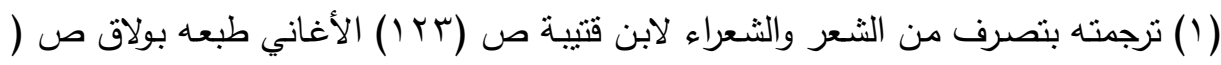
. (1). - $97-17$

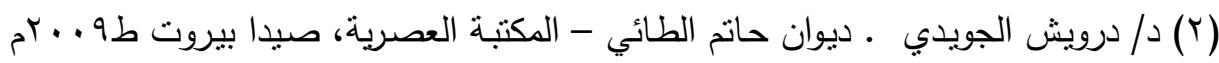

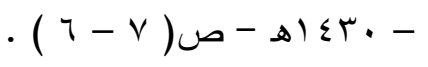




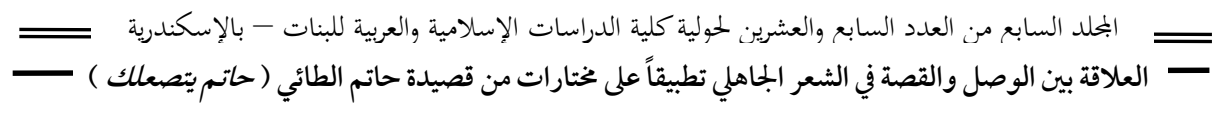

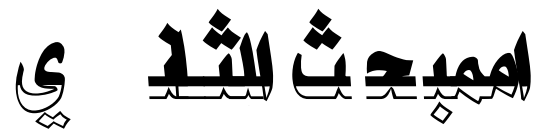

\section{وذشتمل على :}

\author{
أ- التحليل البلاغي للقصيدة. \\ بـ الخاتمة \\ جـ ـ الصادر والمراجع .
}

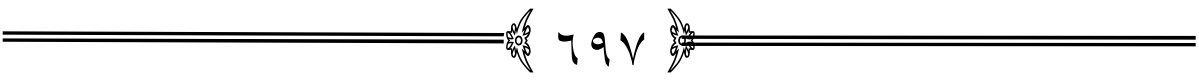




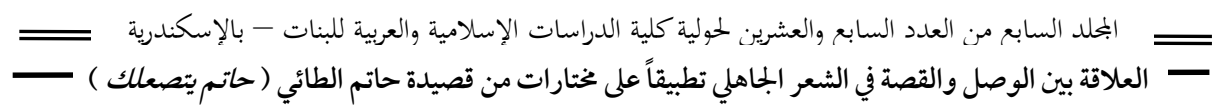

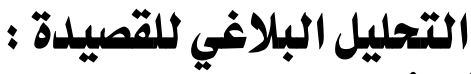

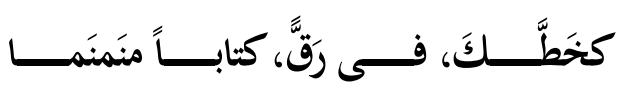

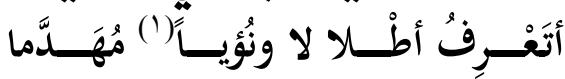

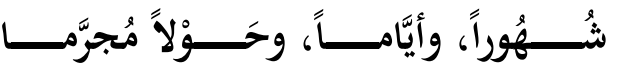
أذاعــتْ بِــهـ الأرواحُ، بعــدَ أنيســها

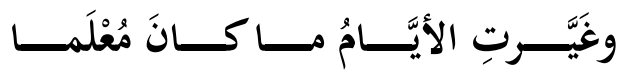

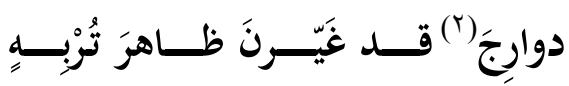

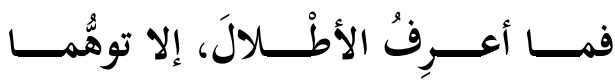

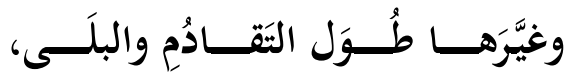
بُدأت القصيدة بالوقوف على الأطلال على عادة الجاهليين حيث يخاطب حاتم صاحبه المتخيل ويسأله عن بقايا ديار قد اندثرت ولم يتنق من منازلها سوى بالي حفرة كانت تحيط بالخيمة لتمنع عنها السيل وبقايا الديار تشبه الخط المنمنم في الورق، مستفهاً فيها الثاعر استفهاماً مجازياً خلق جواً من الفكر والتساؤل وجذب الانتباه لما يُلقى من كلام غاية في الأهمية وكأن لسان حال الثاعر يقول مستتكراً أن يكون هناك من عرف في حياته " أطلالاً ونؤيا مهدمة " ثم تأنى الصورة التشبيهية التي تقوم على تتبيه هيئة الأطلد الدراسة بهيئة كتاب قديم لم يبق منه إلاَّ رموس وإثنارات . هذا، والصورة التشبيهية تكتسب من الجملة الإنشائية ضمن ما تكتسب : إنها تقوم على جعل النواطق والجوامد كائنات حية متحركة أو ثابتة، وأخرى لا حياة فيها ـ وكل منهما له أبعاده وخصائصه وتأثنيره في مشهح يعز علىَّ التصوير له بقلمي، لكن براعة " الطائي" جعلته أي " المشهد لهُه

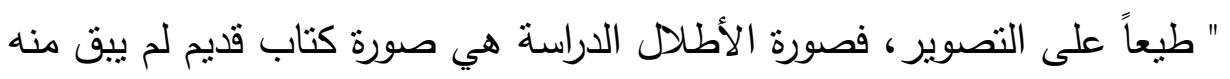
إلاّ رموس وإثارات، وبهذا التصوير التشبيهي أخرج الثاعر الصورة إلى البعد

(1) النؤي : الحفرة التي تحبط بالخيمة لمنع السيل من التسرب إليها - معجم مقاييس اللغة

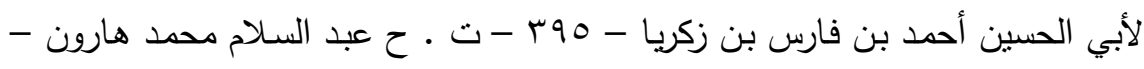

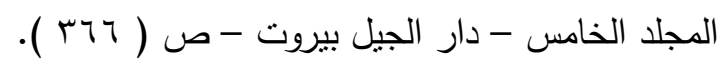

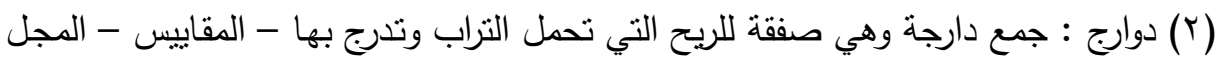

$$
\text { الثاني ( السابق ) • اسم. }
$$




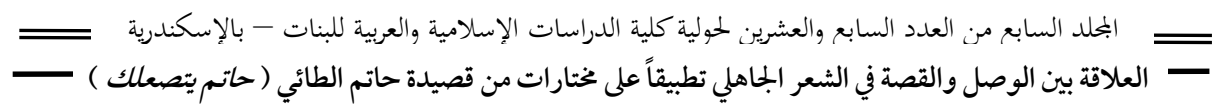

والغرابة، وذللك عن طريق ندرة حضور صورة المشبه به " الكتاب القديم الذي لم يبق منه إلا روس وإثارات " في الذهن عند حضور صورة المشبه ( الأطلال الدراسة ) فثتان ما بين الصورتين، وفى قوله " في رَقَّ" قيد في التشبيه، فأي أداة بلاغية تستطيع أن نقوم مقام التشبيه في هذا المشهد !! فالصورة تستدعى أداة لتصويرها و " حاتم الطائي " هنا أدرك أي الأدوات أصلح لتصوير صورته فهو لا ينقل إلينا معنى بعينه ولكنه يجسد إلينا موقفاً

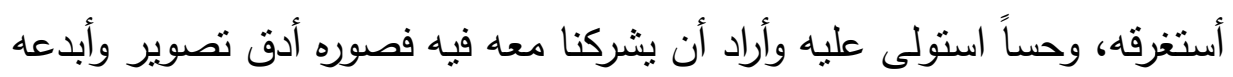

ويأني الوصل : حيث عطفت جملة " ونُؤيا مُهَََّماً" على ": أتعرف أطلالاًا" وهو من باب عطف الجمل المحذوف عاملها . وذذلك للتوسط بين الكمالين، فالجملتان إنشائيتان لفظاً ومعنى والجامع بينهما اتحاد المسند إليه فيهما وشبه التضاد بين المسندين والتتاسب واضح بينهما، فالحديث عن الأطله الدراسة والنؤى المتهمة بينهما تتاسب ولعل الثاعر آثر مجئ الوصل لأنه يتتاسب مع القصص - ليس على الإطلاق - لأنه إضافة جزئيات إلى بعضها تكون في مجموعها مشهداً من المشاهد؛ وذللك لأن القصيدة تحكى قصة صعلكة حاتم نفسه لإنه

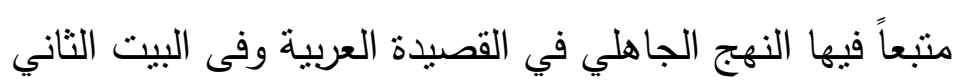

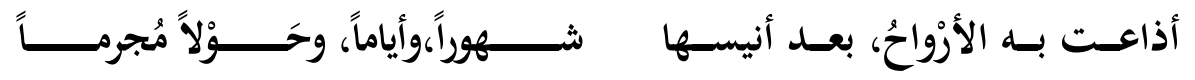

يقول قد وضحت الأرواح أمر الطلل بعد سكونها أثهراً وأياماً ودهراً على ما به من المصائب، والضمير في "به " يعود على " الأطلال" و قوله " بعد أنيسها " كناية عن الحياة . كن

ويعود " الطائي " ثانية ليؤكد على " الوصل " في قوله "شهوراً - أياماً -

حَوْلاً مُجرَّما " من قبيل عطف المفردات بعضها على بعض . لموحل 


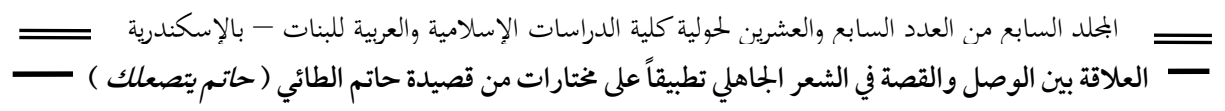

" الأيام " ثم " الحول " على الثهور من " باب عطف الثيء على "ل

مصاحبه " ('). لأن الثهور هي مجموع الأيام ومجموع السنيين .

ولما كانت كل هذه الألوان والظلال البلاغية لا تفي بخصب خيال الشاعر

وسعة أفقه، نجده انطلق بنا إلى ظل آخر في لوحته عن طريق " مراعاة النظير"

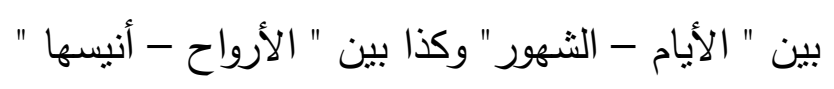

فراعاة النظير امتلكت إمكانيات تصويرية أدت أدواراً فنية متتوعة، ساعدت على إثراء صور " الطائي" وإبراز مواقفه، ولا شك من أن الجمع بين المعاني التي بينها تتاسب أو مراعاة نظير داخل الجمل والصور الثعرية يثير التأمل وينشط واءراء الثعور ، ويزيد الفكرة وضوحاً وتأكيداً . .

هذا، ويأخذ نتكيل الصورة بعداً فنياً أعمق وأرحب بمعنى أنه يوظفها لخدمة موقفه وتلوين صوره وظهورها، وقد تتوعت الظله داخل اللوحة البلاغية؛ ليخرج بنا عن الملل الذي قد يورثه توالى ظله بعينها فنجده يكنى " بالأرواح " عن الموت والخراب، ويكنى عن الحياة بالأنس .

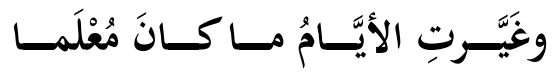

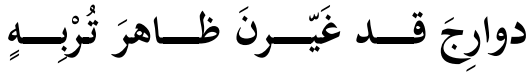

فمـــا أعـرِفِ الأطَـلالَ، إلا توقُّمـــا

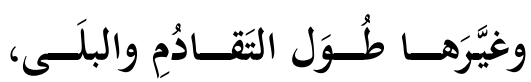

وكَشـحاً، كطي السـابريَّةِ، أهضـما (؟)

تهادى عليها حَليها، ذات بهجـةِة

المعنى : يقول الطائي إن هذه الأطل تهادت عليه الدوارج وهو وصف للرياح أن تتابع مشيها عليها " الأطلال" مشية هادئة ناقلة الرمال من عليها حتى لهى

(1) ابن هشام الأنصاري : مغنى اللبيب عن كتب الأعاريب، ت.ج الفاخوري ، الجزء الأول

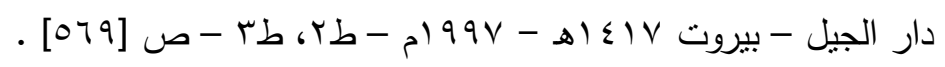

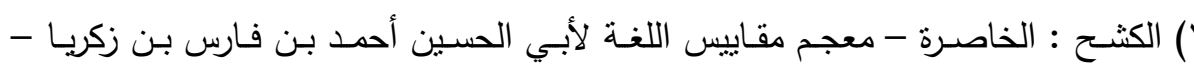

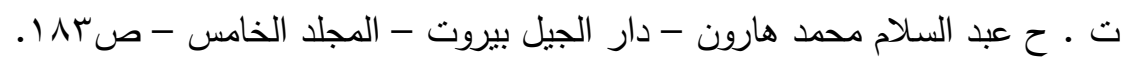




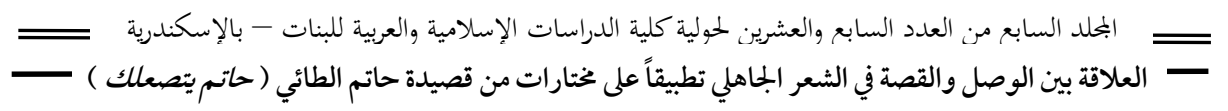

غيرت الثكل التي كانت عليه، ثم أتت الأيام فما كان منها إلاَّ أن غيرت المعالم والمقصود به التاربخ، ولا أتذكر الأطلال إلا قليلاً أو منظراً مشوهاً، وأتنكر الديار قديماً حينما كان فيها أهلها، كما أنذكر تللك الأزياء والملابس الرقيقة الجميلة على التى

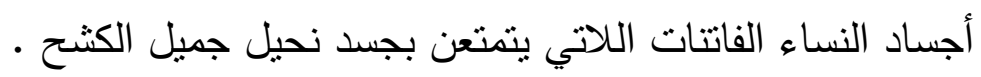
.. هذا، والضمير في " تربه " يعود على ( الأطلال) التي بُدئت بها

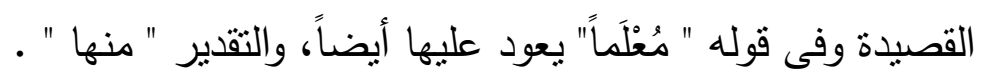
ويأني الوصل بين شطري البيت فى قوله " دوارج قد غيرن ظاهر نربه

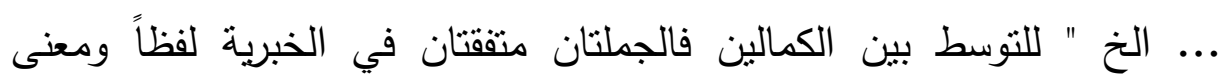
والمسند إليه فيهما واحد وهو " الطلل" والمسند فيهما هو " القوة العارمة الموجودة في الرباح والأخرى الموجودة في الأيام " والجامع بينهما التتاسب وهو واضح في وهو في

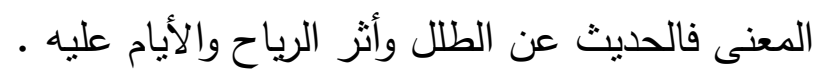

والسر البلاغي للوصل هنا هو نرتيب الجمل الموصولة، من حيث الأقوى فالأقل في القوة " فالرباح أو الدوارج هي الأقوى في التغيير ثم يليها الأيام فالأولى هي هئ

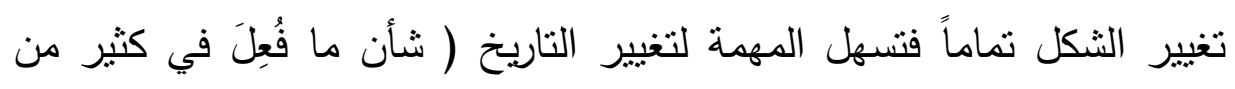

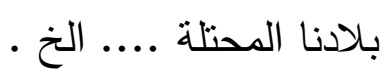

فالغرض من الوصل هنا هو " ترتيب الجمل الموصولة " ويدخل تحته

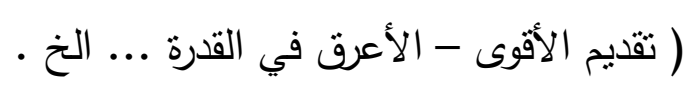

وتقديم الأكثز في العدد، فالأقوى كما في بيتتا هذا - والأعرق ف القدرة

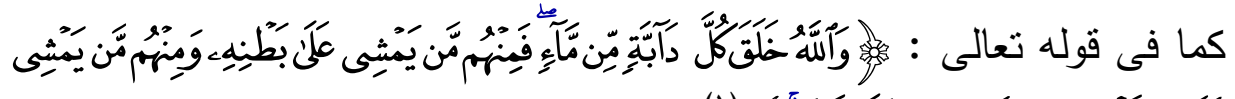

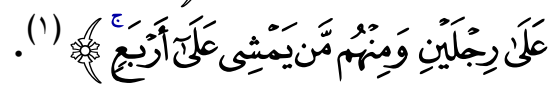

$$
\text { (1) سورة النور - آية (1) (20) }
$$


" فقد جاءت الأجناس الثلاثة على هذا الترتيب ـ كما يقول الزمخشري لتقديم ما هو أعرق فى القدرة وهو الماشي بغير آلة مَثْي من أرجلٍ أو قوائم، ثم هني الماشي على الرجلين، ثم الماشي على اعلى الأبع " ('). وقد يكون الغرض تقديم الأكثر في العدد :

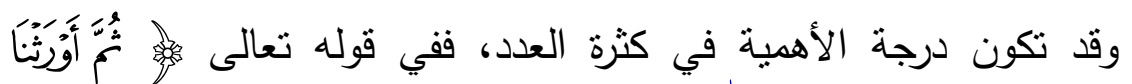

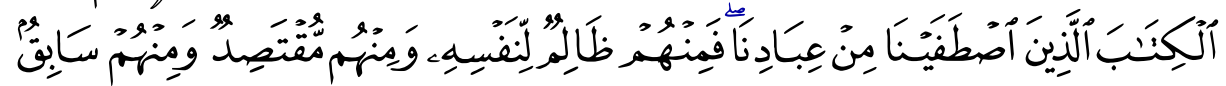

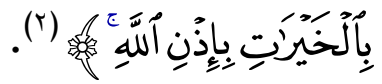

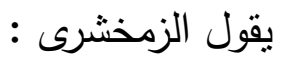

" قدم الظالم ثم المقتصد ثم السابق، للإيذان بكثرة الفاسقين وغلبتهم، وأن المقتصدين قليل بالإضافة إليهم والسابقون أقل من القليل " (־َ). هذا • والبيت صاغه شاعرنا المتفرد على نسق رائع حيث بدأ البيت بالإيجاز بالحذف في " دوارج " والتقدير " ريح دوارج " .

ثم قد التحقيقية الداخلة على الماضي في " قد غيرن " وتكرار الفعل "غير" مع الحفاظ على بنيته من خصائص نتكيل الصورة ولجأ الطائي إلى "الفعل

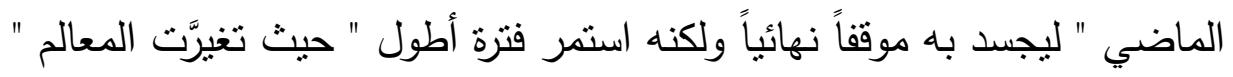
وكان نتيجة طبيعية لما سبق، فالفعل " الماضي " ليس ببعيد والاستمرار ليس بطويل ولكن يظل تصوير الحدث في الماضي أقوى على الرغم من انقضاء وقت قصير على الحدث السابق عليه لأنه نتيجة ونهاية .

ولما كان التاريخ والمعالم عظيمة ليس من السهل محوها أو تغيرها ناسبه

$$
\begin{aligned}
& \text { للتعبير عن ذللك " ما " التي بمعنى " الذي " لمعن }
\end{aligned}
$$

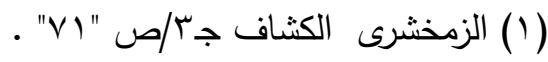

$$
\begin{aligned}
& \text { (Y) سورة فاطر - آية ( Tr). }
\end{aligned}
$$

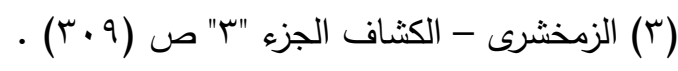




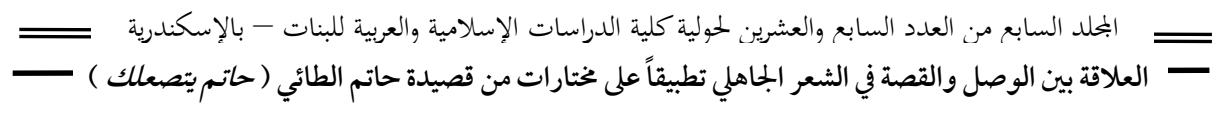

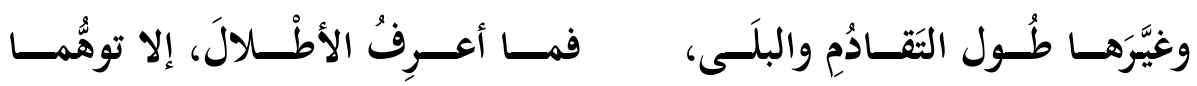

الحديث موصول عن أسباب تغيير الأطلال حتى صارت إلى ما هي عليه والبيت معطوف على سابقه ولما كان البقاء أو طول العهد والمدة من أسباب التغيير ناسبه التعبير بالماضي في [ غيرها - طول ] .

ولقد اعتمد الثاعر على نمط خاص في بيته وذلك؛ للتأكيد على قوة التغيير وشدته وإظهار مدى عظمته حيث بني بيته هذا على نمط خاص من حيث التعبير " باسم الفاعل " في " التقادم - البلى " وفى التعريف بالألف واللام الجنسية من حيث المبالغة في " التقادم والبلى " " والربط بالعطف بين اللفظتين

المترادفتين يثزى الصورة " ( ').

ومن حيث إثراء اللفظ فيهما ودفعها إلى الأصالة وزاد من المبالغة في

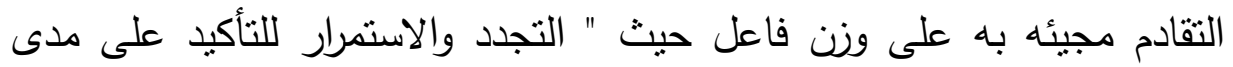

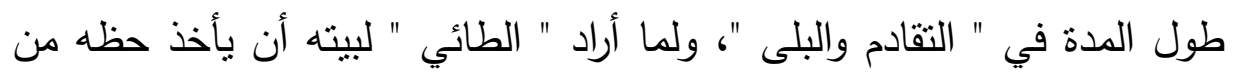

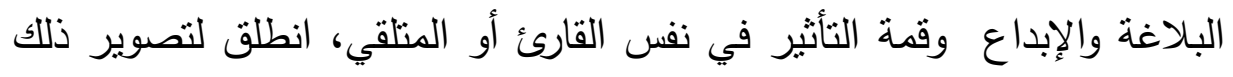
من خلال لون مجازى غاية في دقة التصوير عن طريق المجاز المرسل في قوله

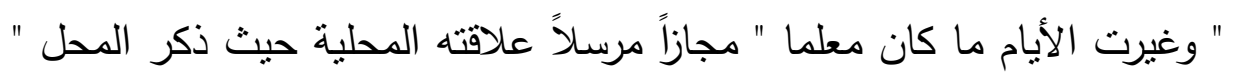

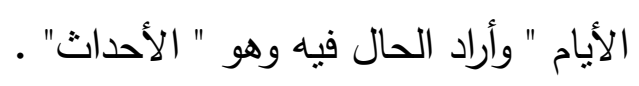
كما أن فيه مجازاً عقلياً ؛ بإسناد الفعل إلى الأيام وأنكر الذي يفعل . ولنتأمل قوله " فما أعرفُ الأطلالَ إلاَّ نَوَهُهَا " الفاء داخلة في جواب

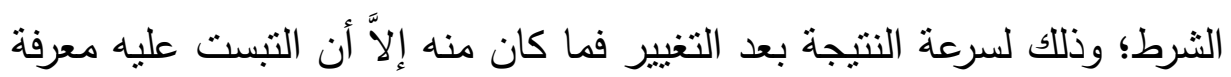
هذه الأطلال لذا صاغه " الطائي " في " استثناء مفرغ" على القصر ، وعلى هذا لهذه تكون " بؤرة الصورة " هي طول التقادم والبلى الذي جعل التعرف على الطلل "

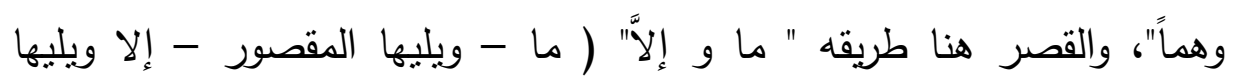

(1) ابن هشام الانصاري - المغنى سبق ذكره الجزء الثاني - ص (UVT) .

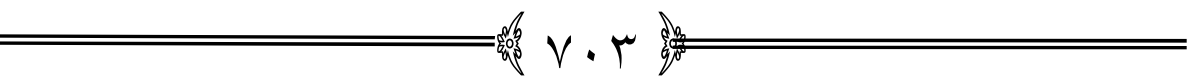




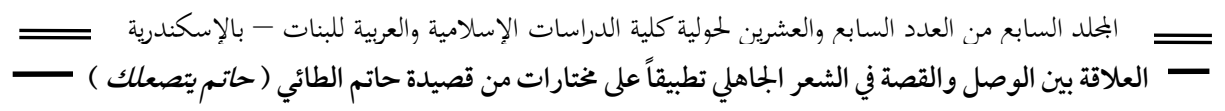

المقصور عليه ) والمقصور هنا هو ( عدم التعرف على الطلل ) نتيجة لطول التقادم والبلى والمقصور عليه هو "التوهم " فهي تضيف للصورة الالتباس وشدة

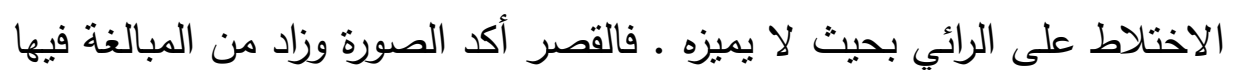

ولتتقل إلى تفصيل آخر في قصة الطلل مع شاعرنا حيث يقول واصفاً تذكره للايار قديماً حينما كان فيها أهلها، كما أتذكر تلأك الأزياء والملابس الرقيقة الجميلة على أجساد النساء الفاتتات اللاتي يتمتعن بجسد نحيل جميل الكثح . يقول

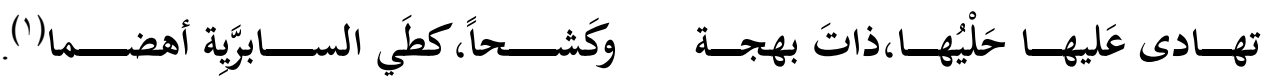
ينتقل (الطائي) إلى ( الغزل) وذللك وفقاً للنهج الذي سارت عليه القصيدة الجاهلية حيث يصف المحبوبة التي تهادى عليها الزينة عندما كانت تسكن هذه ولى

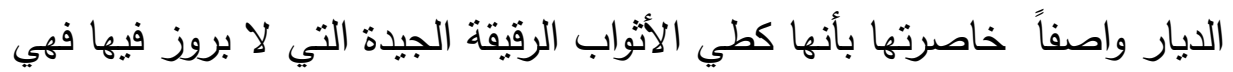

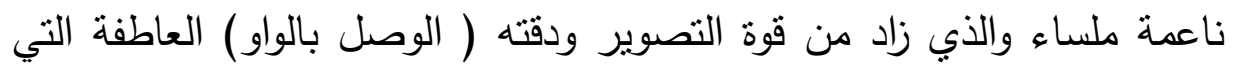

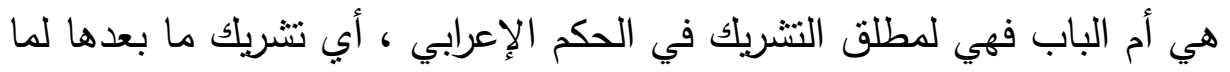
قبلها في الحكم؛ وذلك لغرض بلاغي هو " التوسط بين الكمالين " فالجملتان خبريتان لفظاً ومعنى والمسند إليه فيهما واحد هو " جمال المحبوبة " المكنى عنها

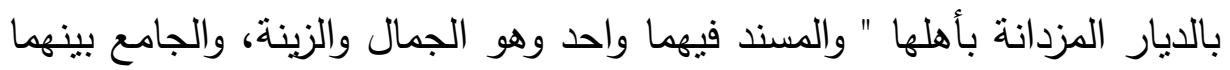

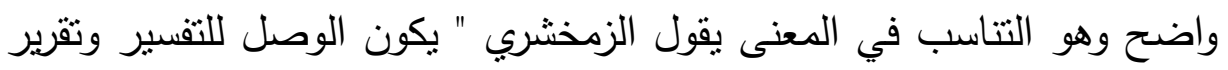
المعنى وللتوكيد، ويأتي الفصل للتوكيد والإيضاح والتفصيل بعد الإجمال "(r).

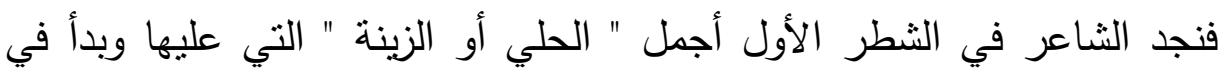

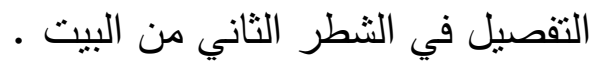

( (1) الكثح : الخاصرة ينظر مقاييس اللغة ( سبق ذكره ) المجلد الخامس - ص ( rم I )

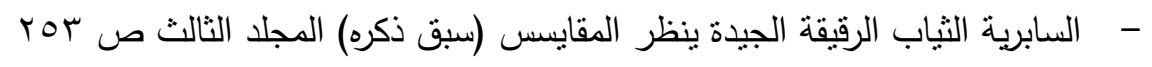

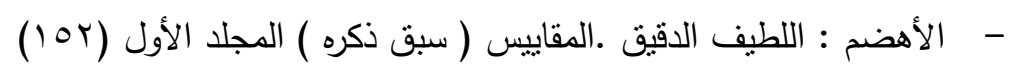

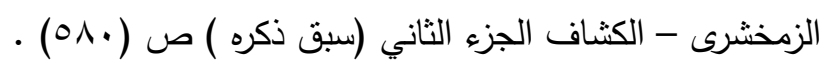


لقد " تهادى " أبي مشى مشية هادئة على هذه المحبوبة حَليها وعبر بلفظ "

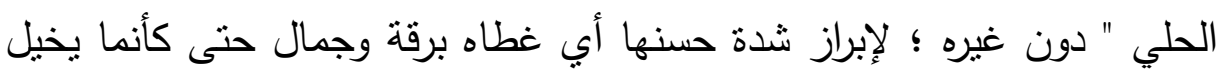
للرائي أنه سار عليها أو مشى عليها وخاصرتها كطي الأثواب الرقيقة الجيدة، كناية عن عدم البروز فيها أو النتؤات .

ثم ينتقل إلى وصف آخر حسي رائع لهذه الحبيية واصفاً نحرها المزين

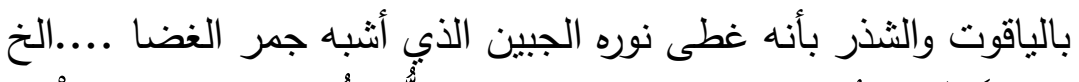

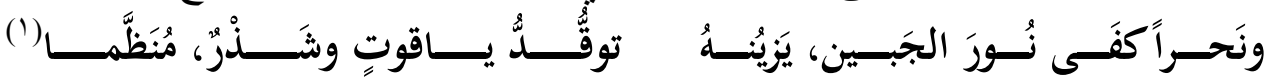

انتقل إلى الوصف الحسي للمرأة، فصرنا بحاجة إلى تصوير صاحبة هذا الجسد وذالك النحر .... الخ، وقد استطاع (الطائي) أن يوظف المفردات اللغوية؛ لتحمل دلالات شعورية وجمالية، إذ أن معظم ألفاظه لم تجمد عند حد معناها المعجمي الثابت " العقيم " وإنما تعدت هذا الإطار؛ ليصبح لهاب إنه أكثر من دلالة فنية تكثف عمق تجربته الثعرية - ومن ثم- اتسمت ألفاظه بالتجدد والثراء الفنيين، في الوقت الذي حققت الإمتاع الفني للمتلقي، وإذا تتبعنا إيحاءات الألفاظ : نجد دقة الاختيار للمفردات وخصوصية الاستخدام، فنجده لما أراد شمول الجمال والزينة بهدوء ورقة لكامل جسدها آثز التعبير "بالتهادي" فهذه

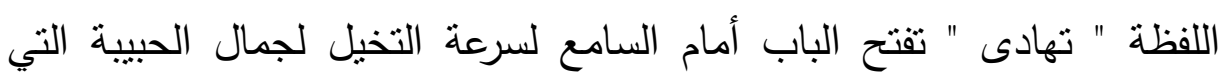

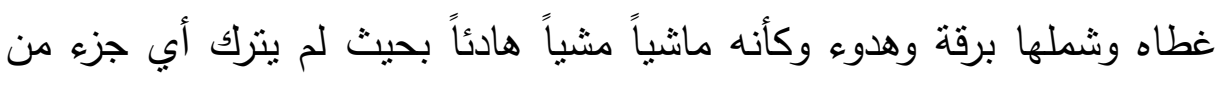

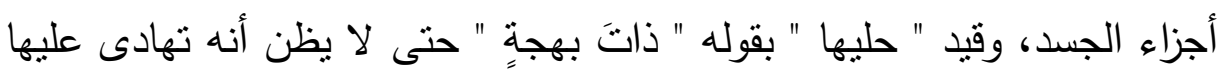

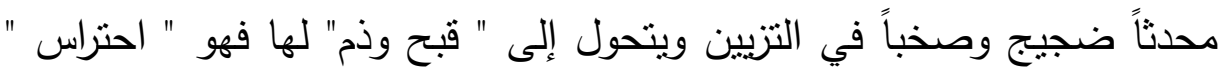
لئلا يتوهم متوهم من أنه غير ذلك أي " تهادى في غير بهجة " وكذا في قوله " أهضما" للتأكيد على دقة ورقة خاصرتها وهي كناية عن " الجمال المثال " .

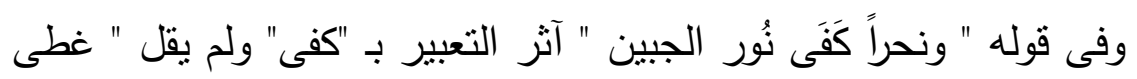

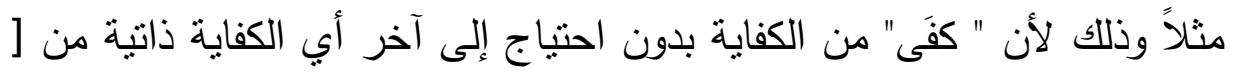

(1) شذر : اللؤلؤ الصغير • ينظر مقاييس اللغة - المجلد الثالث - ص (YOV) 


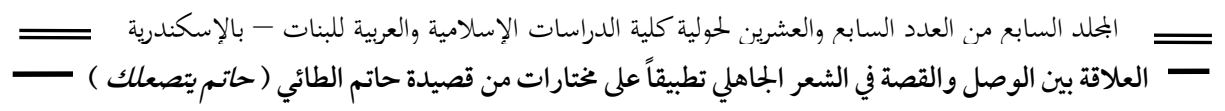

الحبين وحده ]، فلو قال " غطاه " لكان هناك وهم بأنه غطاه ليس بذاته أب ليس من " الجبين وحده " وإنما هناك آخر خارجي، ولكن لما كانت وضاءة النحر لهاه

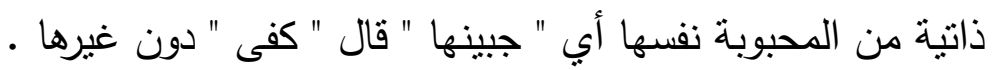

وجعل " توقد الياقوت والثذر" للزينة فقط فقصر دورهما على الزينة أما "

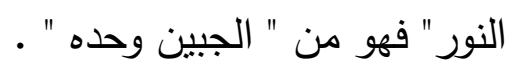
وهذا يدلل على مدى توفيق الثاعر في اختيار ألفاظه بعناية بالغة . وبدلل على الدقة في الاختبار للألفاظ في اللوحة المرسومة والأسلوب المغاير يبدى من قيم المبدع ( الطائي) ومواقفه بقدر ما يستر من عواطفه المباشرة .

لقد رسم الثاعر لوحته البلاغية بظلال عدة، كل ظل منها أضفى على اللوحة خلابة و سحراً، فنجده عمد بنا إلى ظل مجازى عن طريق الاستعارة

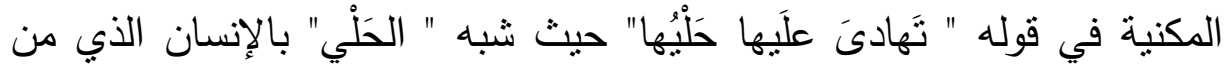
شأنه يمشى مشية هادئة ثم حذفه وأبقى على ذكر لازم من لوازمه وهو " التهادي

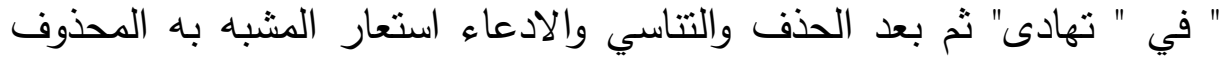

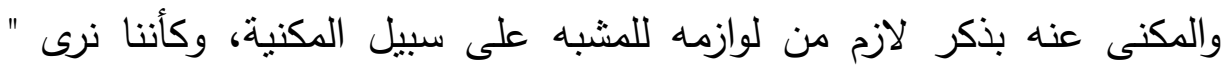

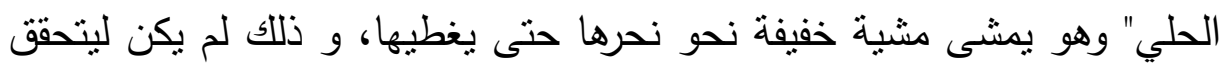
من خلال التعبير الحقيقي، يقول الإمام عبد القاهر الجرجاني عن الاستعارة : " فإنك لترى بها الجماد حياً ناطقاً، والأعجم فصيحاً، والأجسام الخرس

مبينة، والمعاني الخفية بادية جلية " (1).

ومما سبق يتضح أن " الطائي" قد استطاع أن ينقل من خلال تصويره

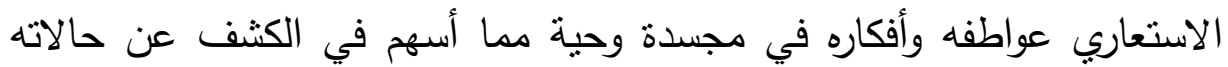

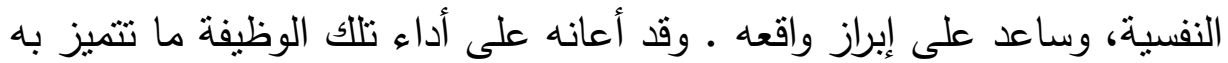
الاستعارة من قدرة على التكثيف والإيحاء من خلال الإيجاز والمبالغة .

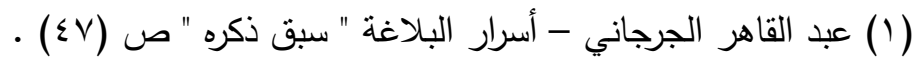


فهي كما يقول عنها الجرجاني : " تعطى الكثير من المعاني باليسير من اللفظ، حتى تخرج من الصدفة

الواحدة عدة من الدرر، وتجنى من الغض الواحد أنواعاً من الثمر " ( '). أما عن مصدر التأثير فيها فيرجع إلى عملية " التجسد" التي هي أقرب إلى إدراك الإنسان، كما يرجع إلى صدور " الطائي" في صوره عن إحساس

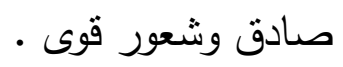

وفى قوله " تهادى " تصوير لمدى تغطية الحلي لها تغطية رقيقة هادئة وكأنها تغطيها جزء جزء فالطائي موفق في اختيار ألفاظه فكلها أتت معبرة

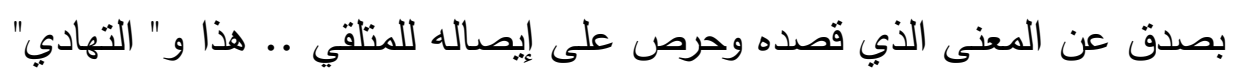

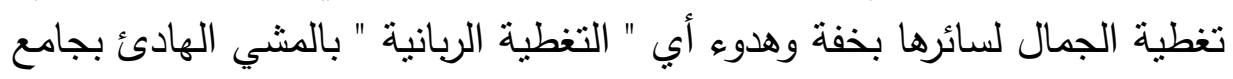

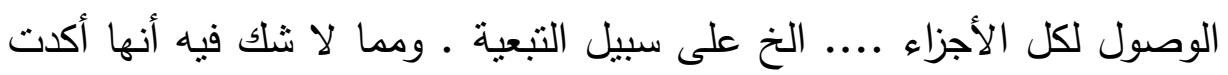

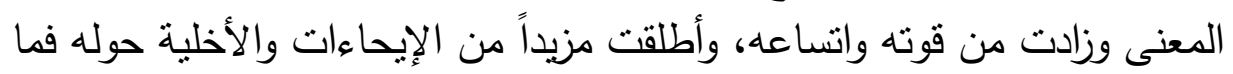
زاد من عمق المعنى واتشاعه وبلاغته . . . هذا، وفي قوله " وكثحاً؛ كطى السابرية، أهضما" ظل آخر في اللوحة

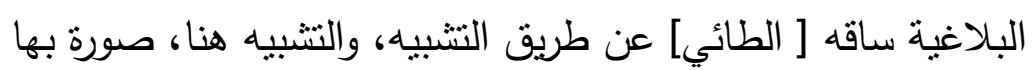

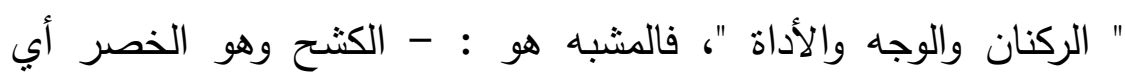
خاصرة الحبيبة، والمشبه به : - هو هيئة الأثواب الرقيقة الجيدة التي لا بروز

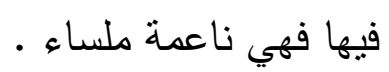

فالطرفان المشبه مفرد حسي، والمشبه به مركب حسي، والوجه مركب

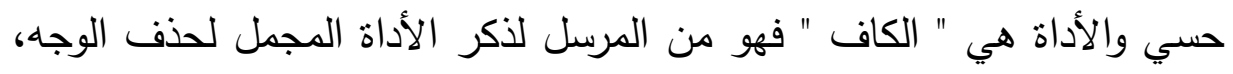
والغرض من التشبيه هو بيان حال المشبه وذللك من حيث دقه جمالها وزينتها

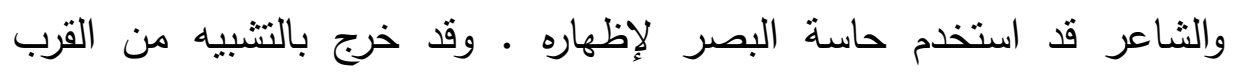
والابتذال إلى البُعدِ والغرابة، عن طريق التقصيلات في المشبه به، في ( كطي

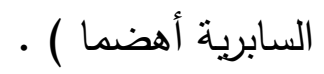

( (1) عبد القاهر الجرجانى - أسرار البلاغة " سبق ذكره " ص (₹) . ב $V \cdot V$ 


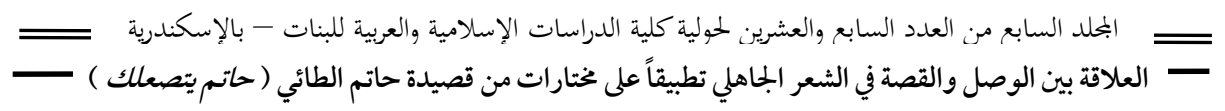

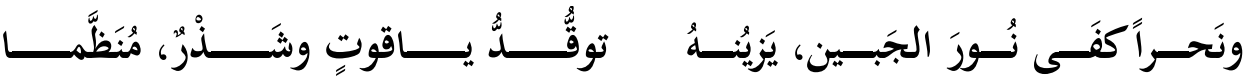

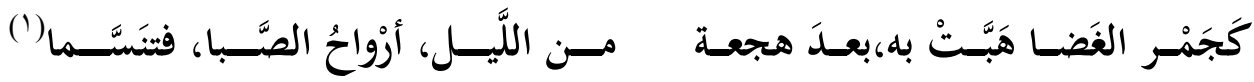

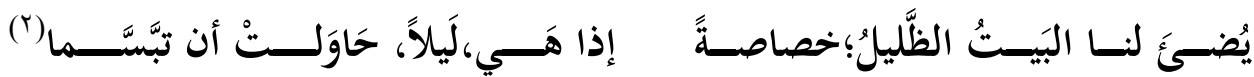

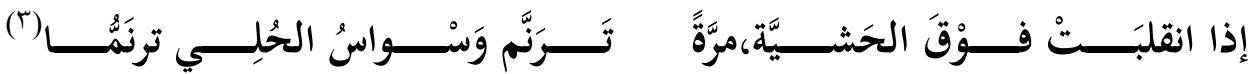

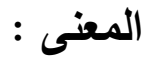

الحديث موصول في العزل بصفات الحيبية الحسية والمعنوية، ماضياً نحو

وصف جمال الحبيية الحسي، يقول واصفاً نحرها الذي يزينه توقد ياقوت وشذرّ

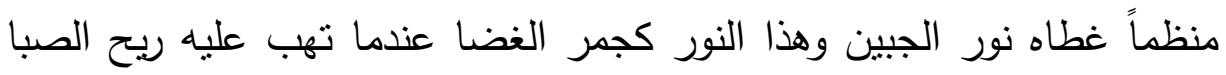

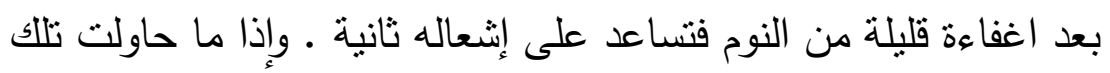

المرأة الجميلة أن تبتسم أو تفكر في التبسم في البيت ليلاً في ظلمة الليل البهيم،

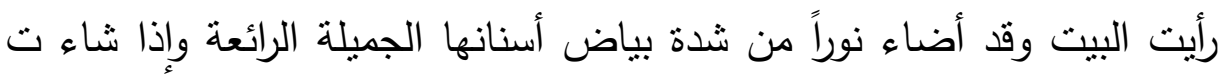
محبوبتي أن تتقلب بين حنيات الفراش، تسمع لحليها ترنما، دلالة على الدعة

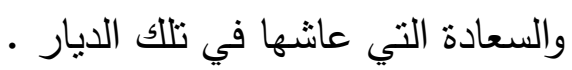

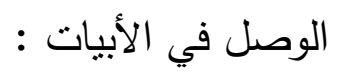

البيت الأول في قوله " توقد ياقوتٍ وشذرٌ " من قبيل عطف المفردات وذلك

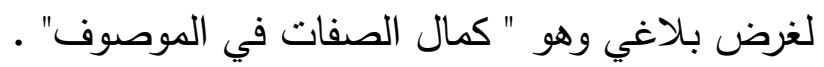
يقول الزمخشري في الكثاف :

(1) جمر الغضا : أجود النار عند العرب لأنها من شجر الغضا سريع الاشتعال وذي الرائحة

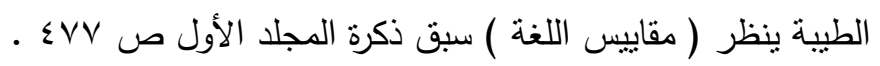

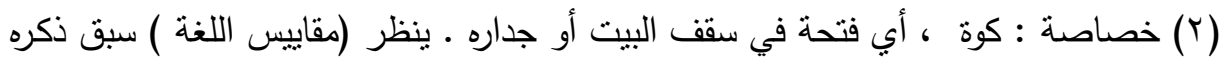

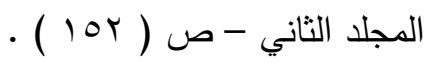

(r) الحشية : الفراش ينظر ( مقاييس اللغة ) سبق ذكره - المجلد الثاني ص ( 10 ( ) $\mathrm{V} \cdot \Lambda$ 


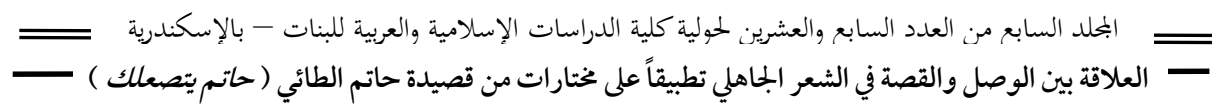

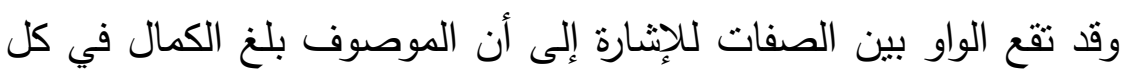

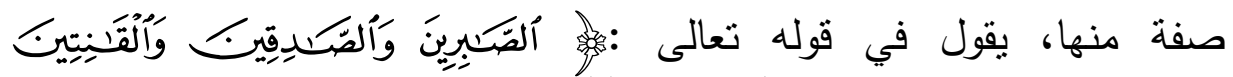

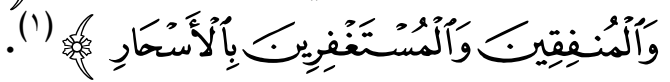

" والواو المتوسطة بين الصفات : للدلالة على كمالهم في كل واحدة منها"

هذا .، ولما كان الوصل يتتاسب مع " القص" - ليس على الإطلاق -

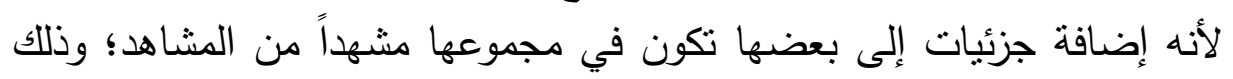

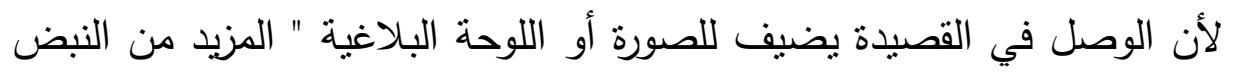

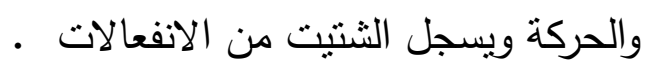

.. هذا، وفى قوله " نور الجبين " من التشبيه المؤكد المجمل لحذف الوجه

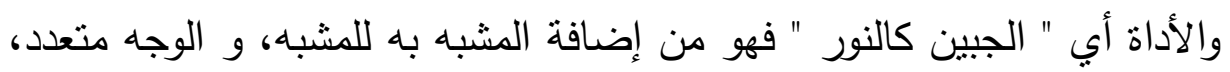

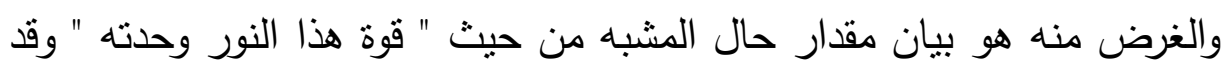

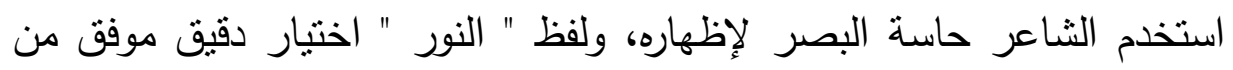

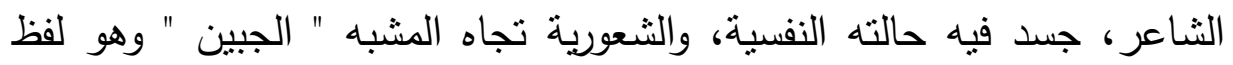

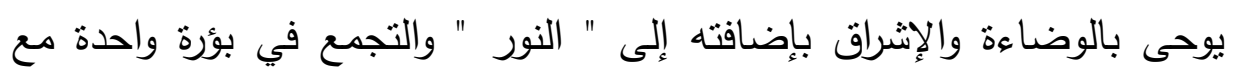

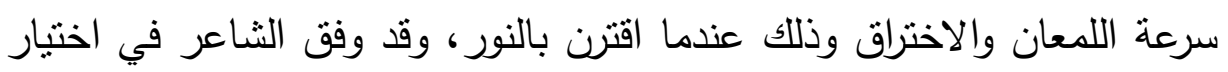

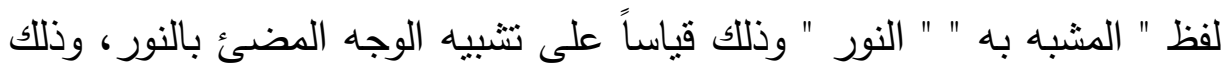
دلالة على خصب خيال الثناعر وسعة أفقه .

والبيتان من قبيل التشبيه التمثيلي، فنجده شبه هيئة النحر الذي يزينه توقد الياقوت والثذر المنظما وقد غطاهما نور الجبين .

والمشبه به : هيئة جمر الغضا الذى هبت عليه بعد هجعة من الليل أرواح

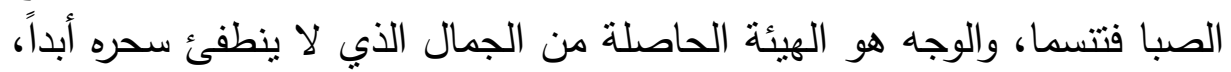

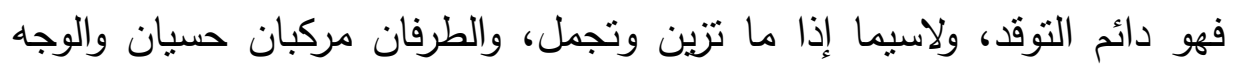

$$
\begin{aligned}
& \text { مركب حسي دو دم } \\
& \text { IV: (1) سورة آل عمران }
\end{aligned}
$$

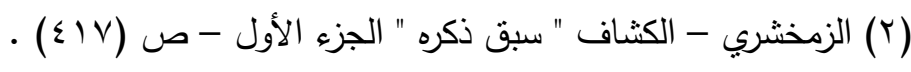


.. هذا وقد استخدم " الطائي " حاسة البصر لإظهاره وهو من المرسل

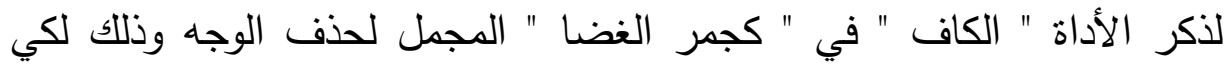
تذهب النفس فيه كل مذهب ولكي يدعو للفكر والتساؤل، والغرض من التشبيه هو

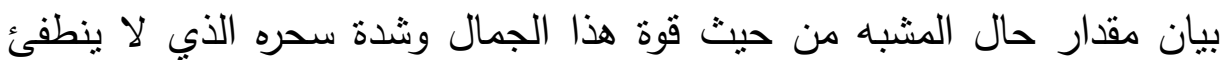

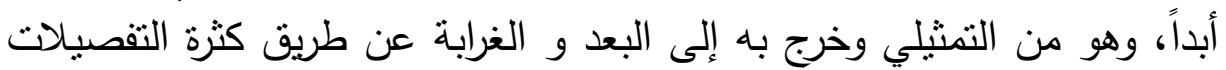

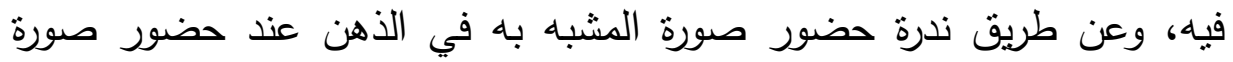

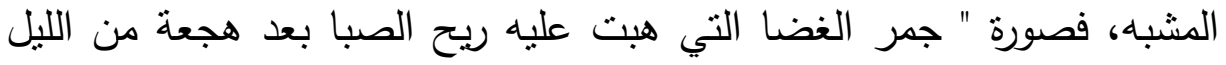

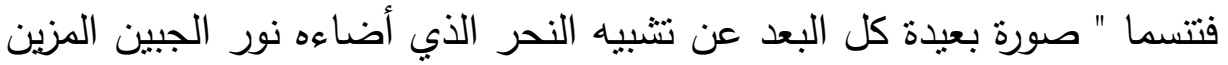

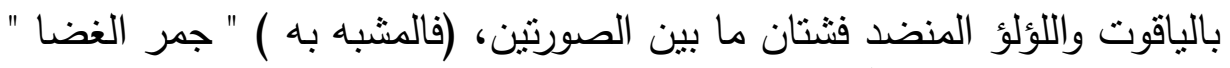

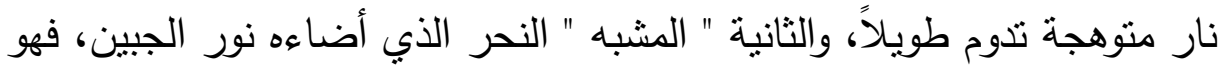

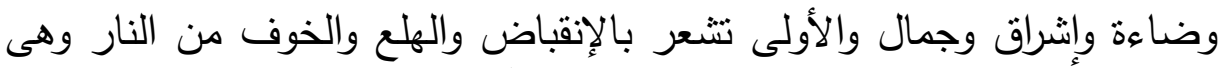

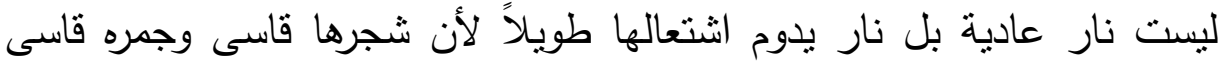
فالطائي أتى بأبعد صفة لأقرب موصوف فهو بدخل بلد أكثر من عنصر في نكوين

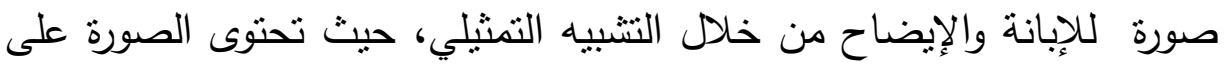
أكثر من جزء في كل من طرفيها، مما يعطى للصورة مدى أرحب .

$$
\text { يقول عبد القاهر الجرجاني : }
$$

" فاعلم أن التشبيه عام والتمثيل أخص منه، فكل تمثيل تشبيه وليس كل

تشبيه تمثنيلاً " (') أن أن

هــ..

وفى قوله " بعد هجعة من الليل" إحتراس لئلا يتوهم متوهم بأنه يمكن أن ينطفئ وضاءة هذا الجمال عند النوم •

وينتقل " الطائي " إلى وصف محاولة تبسم الحبيبة أو تفكر في التبسم في البيت ليلاً في ظلمة الليل البهيم، رأيت البيت وقد أضاء نوراً من شدة بياض أسنانها الجميلة الرائعة . لائة فئة

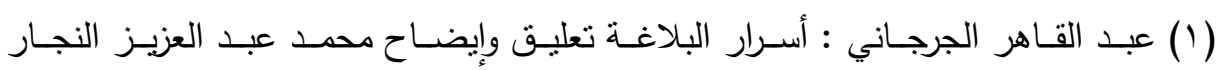

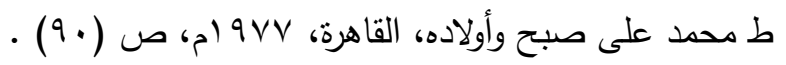




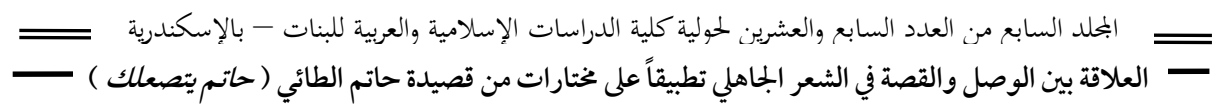

ويمضى بنا " الطائي " لتصوير ذلك المشهح عن طريق لوحة بيانية رائقة التصوير، دقيقة الأجزاء ظللها عن طريق النتبيه، فنجده شبه : هيئة محاولة

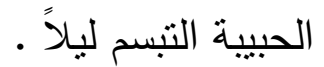

والمشبه به : هيئة الضوء الذي يضئ البيت الظليل في الليل البهيم • والوجه : الهيئة الحاصلة من ظهور شئ مضئ وسط شئ مظلم والطرفان مركبان حسيان، هذا وقد استخدم الثاعر حاسة البصر لإظهاره وهو من المؤكد

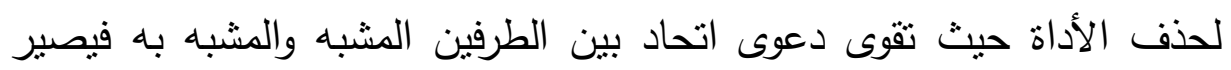
المشبه عين المشبه به، ومن المجمل لحذف الوجه وذللك؛ لكي تذهب النفس فيه كل مذهب ولكي يدعو للفكر والتساؤل، والغرض من التشبيه هو بيان مقدار حال

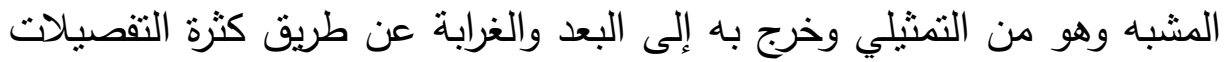
في المشبه به، وفى وجه الثبه، وجعل الطائي الحاسة المستخدمة لإدراك النشبيه هي

البصر • وذلك لما لها من أهمية قصوى فهي حاسة يتوقف عليها قوام الإنسان كله .

والثاعر موفق في اختيار ألفاظه فكلها أتت مصورة للمعنى الذي قصده أنم تصوير وأبينه، " فالطائي" خص في البيت بالظليل ولما كانت الكناية تعطينا

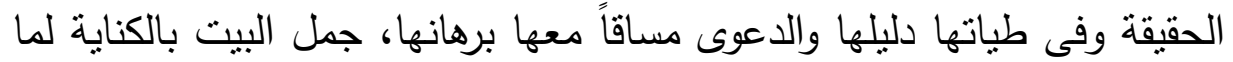
فيها من دقة في التصوير وروعة الإبداع • وخص البيت "بالظليل" لأنه يكون موغلاً في الظلمة والوحشة فهو بيت أو سقيفه من سعف النخيل والخشب موغل في شده الظلمة . وقوله " خصاصة " أي بيت به فروج وذلك كناية عن كونها لا تذهب إليهم في بيتهم، بل بدخل ضوء تبسمها من فروج بيتهم الظليل ومنه إلى كونها عفيفة

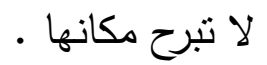

ولنتأمل جمال أسلوب الثرط في الثطر الثاني من البيت في قوله " إذا هي، ليلاً حاولت أن تثبسم " . 


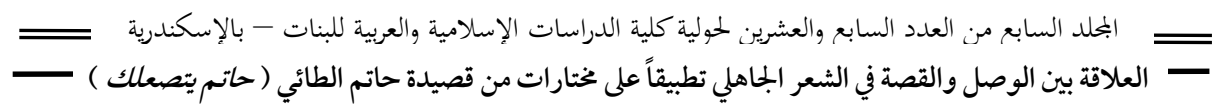

وفعل الثرط " حيث إذا هي حاولت مجرد التبسم " كان الجواب " تضئ لنا البيت الظليل خصاصة : ونجده قدم الجواب على فعل الثرط وذلك استجابة لمتطلبات الصنعة الفنية للقصيدة فنرى التقديم والتأخير جلياً عند " الطائي " فنرى ولجي تقديم " المفعول " على " الفاعل " والتصاقه بالفعل، وتقديم الجواب على فعل

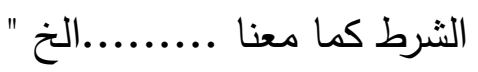

فأسلوب الثرط من أدق وأطرف الأساليب التي يلجأ إليها المبدع أو الثاعر فإنه يقدم مقدمة وهى قد تكون من المتعارف عليه أو من صنع خياله

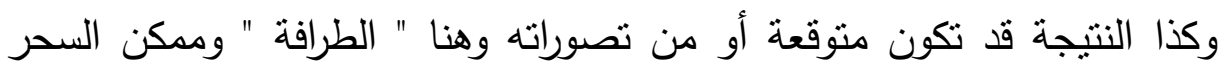

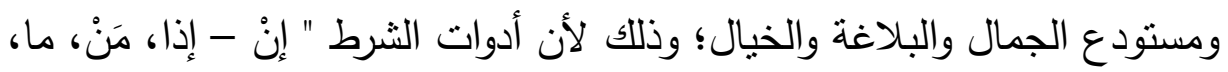
مهما، كلها، لولا عل......

من حيث عملها الجزم أو عدمه ثم الأهم وهو ما بعنينا بلاغياً من خلال

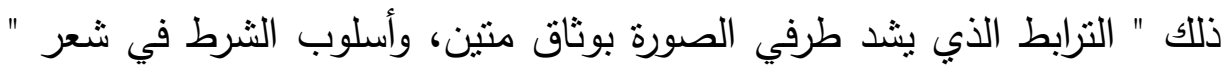
الطائي" موضوع عذب الإيقاع يفيض بأخصب الصور البلاغية من حيث

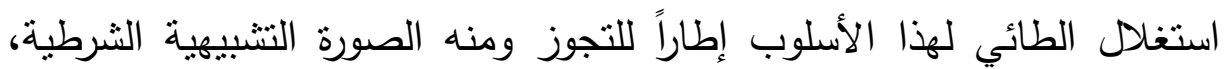

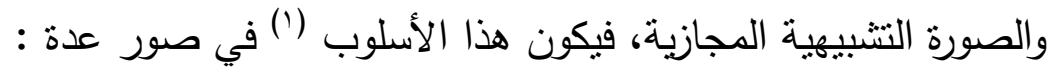
1- التجوز في المقدمة الشرطية - أي " فعل الشرط " .

ץ- التجوز في النتيجة المترتبة على هذه المقدمة - أي " جواب الثرط"

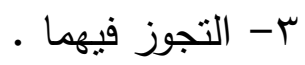

... هذا، ولما أراد شاعرنا للوحته مزيداً من السحر والإبداع نجده يأتي في رئ نصه بألوان مجازية متضافرة لتعطى رسماً خيالياً دقيق الإيقاع عذبه، بديع

(1) الثرط هنا " فرغ " من دلالته الثرطية، فإذا تتصرف دلالتها إلى الظرف المحض فهي هنا

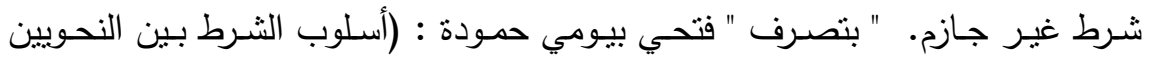

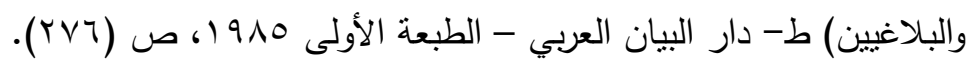
وبهذا يكون الثرط عند الطائي لم يقف عند استخدام واحد وإنما تعدى إلى أكثر من دلالة. 


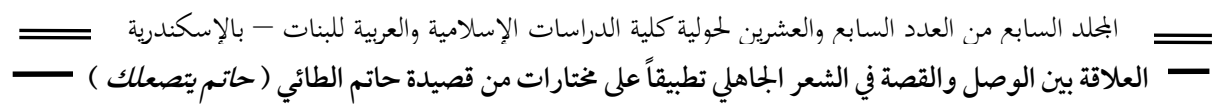

التصوير رائقة، من حيث أتى بلون بديعي وهو " الاحتراس" أو التكميل في قوله "

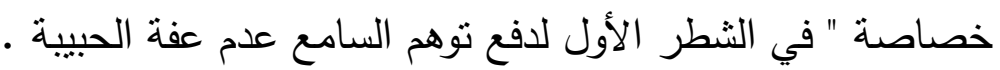
والآخر في قوله " ليلاً" لدفع توهم السامع يمكن أن تكون الإضاءة مصدرها

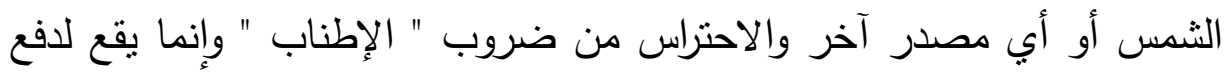

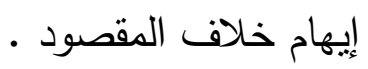

\section{.. هـذا،}

وآثز التعبير بلفظ " خصاصة " للتأكيد على قرارها في بيتها وعفتها فهي لا

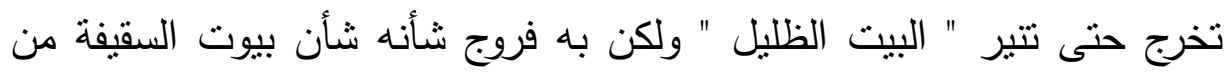
الخشب والأشجار وسعف النخيل، بها فروج لاخول الضوء، وبالتالي يدخل ضوء تبسمها منها ـ و لا أدل على ذلك من إذا لو حذفت "من " البيت وقال :

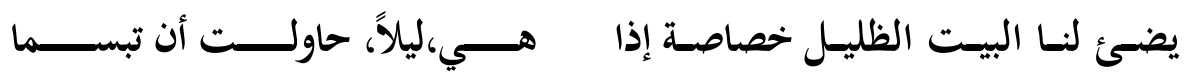

لتقلب المعنى للعكس نماماً وصار المعنى أنها تذهب له " ليلاً"وتتحول العفة إلى غيرها أو العكس .

فالثاعر دقيق في اختيار ألفاظه بعناية فائقة لتصوير مراده أتم تصوير وأوفقه،

ولتتأمل معي " المبالغة " الثديدة في قوله " يضـئ لنا البيت .... الخ إلى

قوله " حاولت أن تبسما " فهي تعد منفذاً لجملة من الخواطر الذاتية، أو إطار يبدى من قيم المبدع ومواقفه بقدر ما يستر من عواطفه المباشرة . وآثز التعبير بلفظ " وسوَاسُ" في قوله :

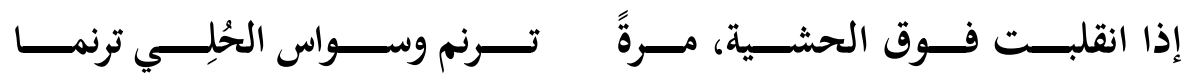

وذلك للالالة على " إطاعة حليها " لها حتى في نومها فهو عند ما يحدث صوناً عندما تثقلب فهو وسوسة مع نرنيم وذلك كناية عن الدعة والسعادة التي

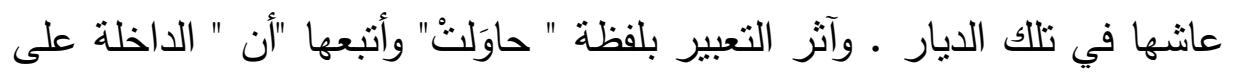




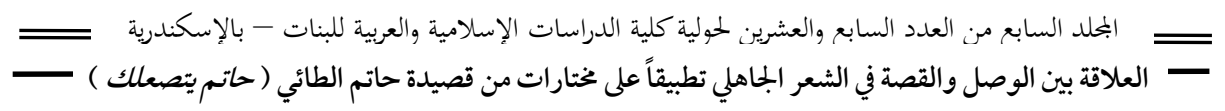

المضارع، و ذلك للالالة على أن جمالها على غير " مثال سابق" فهي ساحرة حتى في مجرد المحاولة للتبس، فما باللك إذا هي تبسمت بالفعل ولكي يدع مجال للذهن أن يتخيل وللفكر أن يسرح في هذا الجمال غير المعهود فهي كناية عن بن في شدة الجمال الملموس لهذه الفتاة .

وفى استخدامه التعبير بالمضارع في المقطع الغزلي " يضئ - تبسما - تَفئ يزينه - توقد - تتسما - تهادى - ترنم - ترنما " " الطائي " موفق في اختيار

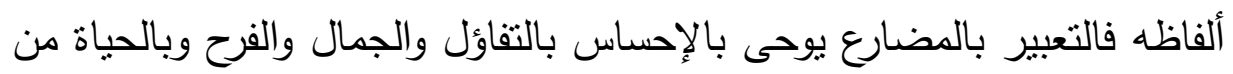

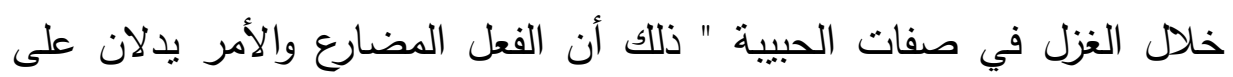
الحياة والحركة والتجدد، وما يمكن أن يتصل بهما من فرح بالحياة وتفاؤل بها أما الماضي المنتهى فقريب في الدلالة على الموت والفناء وعدم التقبل للحياة والواقع بهن أو التقبل اللا إرادى لهما وعدم الرضا عنهما " (').

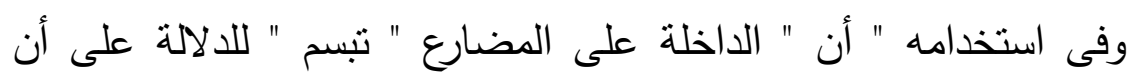
مجرد محاولة التبسم منها مشكوك فيها فهي ليست حقيقة مؤكدة . والحديث موصول عن صفات الحبيية الحسية، مانه يقول :

" إذا انقلبت فوق الحثية مرةً "

المعنى : يصف الثاعر حبييته بالرقة حتى في نومها فإذا ما انقلبت في مره فراشها كان بهدوء ورقة حتى لا يسمع ضجيج حليها وإنما ترنم ووسواس ولما أراد " الطائي " وصف حبييته بالتفرد والمثالية حتى إذا ما انقلبت فى فراثنها وهى لنى

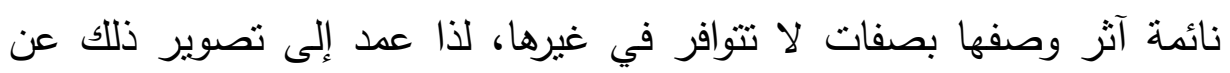
طريق " الثرط " في بداية البيت " إذا انقلبت " .

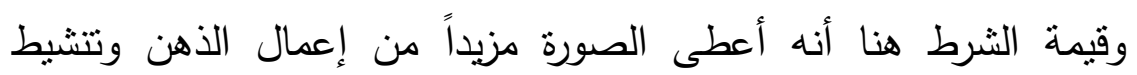
الشعور ويقظة الانتباه؛ وذلك من حيث انتظار الجواب أو توقعه وواضح في تلك إنه

(1) د/ طه وادي : شعر ناجى الموقف والأداة، ط دار المعارف " الثانية " القاهرة ال191م. 
المقطوعة الغزلية من أن أسلوب الثرط هو المجال الخصب عند " الطائي "ومن أنسب الأدوات التي استخدمه لعرض لوحاته بل ومن أهم الوسائل التي استخدمها لإبراز موقفه؛ لما له من أهمية في إثارة الانتباه وتتشيط الثعور والدعوة للتساؤل

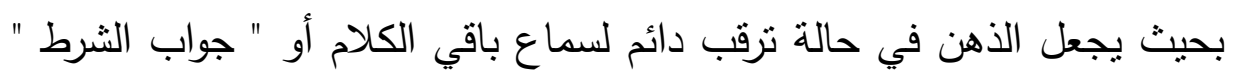
حتى تكتمل الصورة في ذهن المتلقي أو السامع " أسلوب الثرط من أطرف بـ بـاف الأساليب التي يلجأ إليها المبدع يقدم مقدمة ثم يترتب عليها نتيجة، والمقدمة قد دئ تكون من المتعارف عليه، أو من صنع خياله، وكذا الجواب أو النتيجة، قد تكون متوقعة أو من تصوراته وهنا الطرافة " ('). والطرافة تلك هي التي تكون منها المبالغة كما معنا حيث استغل "الطائي" أسلوب الثرط إطاراً للتجوز التي أعطى الصورة البلاغية مزيداً من الحرية

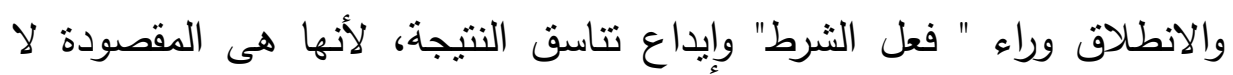
المقدم، فيأتي المجاز ليرقى بها في آفاق الثاعر بفنه الذي وجد من بضيف إليه

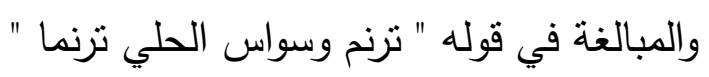

في رأيي : أنه " غلو " (ז) وهو ما يكون الوصف فيه غير ممكن عقلاً ولا عادة وهو نوعان " مقبول ومردود " . أما هنا فهو من الغلو المقبول؛ لأنه تضمن نوعاً حسناً من التخييل فنجده

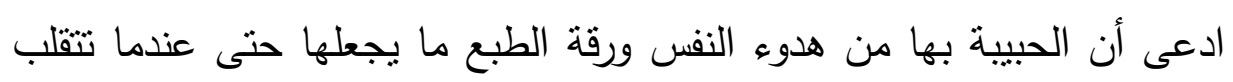

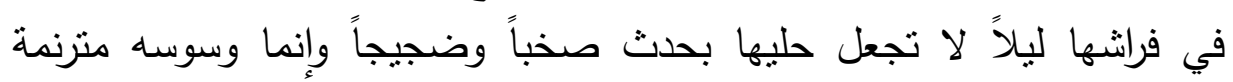

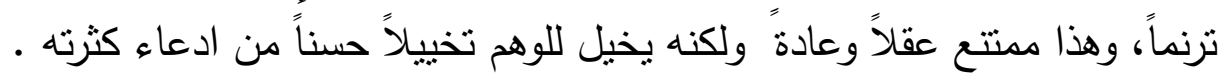

(1) د/ فتحي بيومي حمودة : ( أسلوب الثرط بين النحوبين والبلاغيين " ط دار البيان العربي

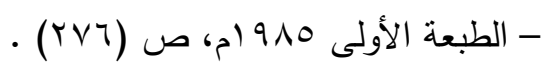

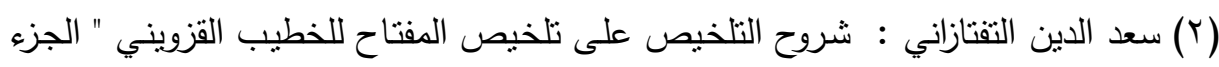

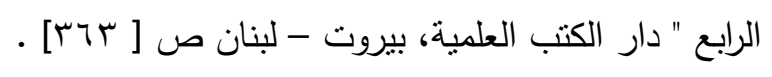




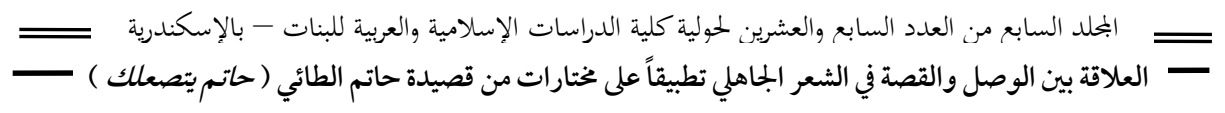

وفى رأيي : إن المبالغة هدف من أهداف البيان، وثمرة من ثماره فيها

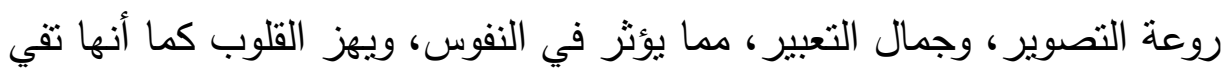
بحاجة المتكلم وتصور ما يجول بخاطره، شربطة عدم الغلو أو الإقراط . وفى رأيي : إن الصورة نستدعى أداة لتصويرها والثاعر أو المبدع أقدر

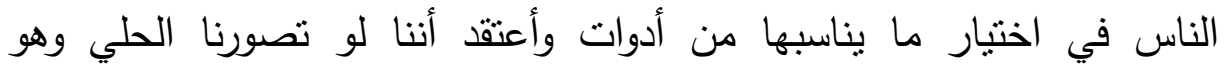
يوسوس بعضه بعضاً منرنماً وهى تتقلب،كانت الصورة أقدر في أخذ العقول

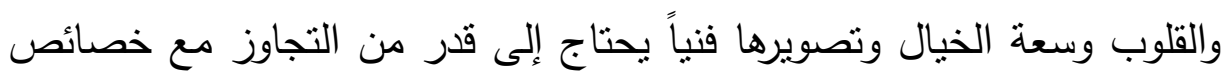
الفعل " الماضي والمضارع" والرضوخ إلى السياق وتحولاته التي يكدثها في أزمان الأفعال، الفعال

ولما أراد الثاعر التتويع في الأسلوب وعدم الوقوف به على لون بلاغي واحد وذلك؛ لكي يكسر الرتابة والملل الذي قد يجلبه سير الأساليب أو الظله الـله البلاغية على شكل واحد، عمد بنا نحو لون آخر في ظلال لوحته وهو الاستعارة

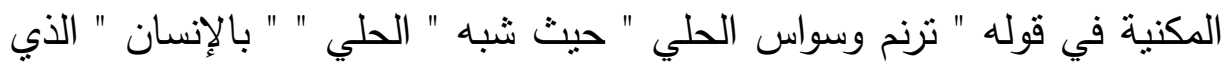
يذهب ويجئ ويوسوس ويترنم ......الخ

واكسبه ما للإنسانية من صفات ثم حذف المشبه به " الإنسان " وأبقى على ذكر لازم من لوازمه وهو " الترنم - الوسوسة " ثم استعار المشبه به المحذوف به بهن والمكنى عنه بذكر لازم من لوازمه للمشبه على سبيل المكنية ـ والقرينة تخييلية

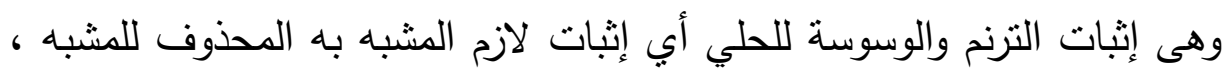
واثبات هذا اللازم استعارة تخبيلية .

هذا .. وترتبط القيمة الفنية للصورة بمدى قدرة الثاعر على التأثير في النفس من خلال تجسيده للمعنوي وتتخيص ما هو غير إنسان أو تجريده؛ وإدراكنا للأشياء المحسوسة وتأثرنا بها يكون أكثر وأقوى من المعنى التجريدي، ومن هنا بدأ يتضح أن " الطائي " قد استطاع أن ينقل من خلال تصويره الاستعاري عواطفه وأفكاره في صورة مجسدة وحية مما أسهم في الكثف عن 
حالاته النفسية، وساعد على إبراز واقعة وقد أعانه على أداء تلاك الوظيفة ما تتميز به الاستعارة من قدرة على " التكثيف والإيحاء " وذللك من خلال [الإيجاز والمبالغة ] وبلاغة الاستعارة : بله الاعيرة

إنما تكون بما فيها من إيداعات وإثارات فنية يحملها اللفظ وما ينطوي تحته من انفعالات، وأحاسيس وتلك الروح التي يبثها " الطائي " هي التي تمنح ألفاظه القوة والحيوية كما أن جمالها أتى من أنها تصور المعنى للسامع تصويراً مؤثراً في النفس فيقر في الأذهان مع الإيجاز والمبالغة المقبولة بسبب تتاسى التشبيه وما يتبع ذلك من تصوير المشبه بصورة المشبه به ـ هذا، والثاعر موفق في اختيار ألفاظه حيث أتت كلها دقيقة في موضعها، قوية الدلالة على المعنى المراد

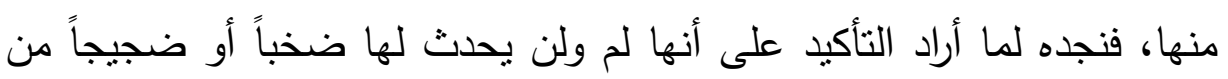
حليها أثناء تقلبها ليلاً وإذا حدث فإنما يكون ترنماً ووسوسة أكد هذه الفكرة بقوله "

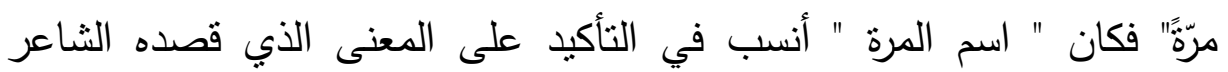
وحرص على إيصاله للمتلقي، وينتقل بنا " حاتم الطائي " إلى المقطع الثالث من

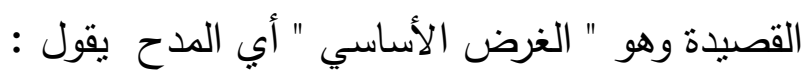

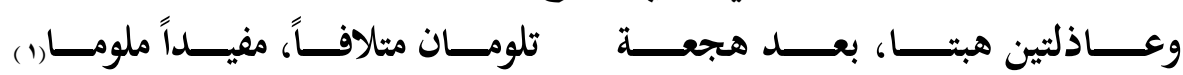

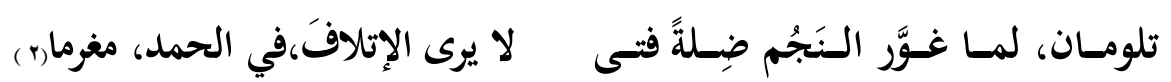

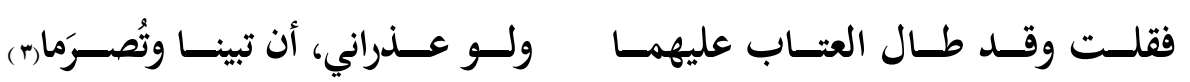

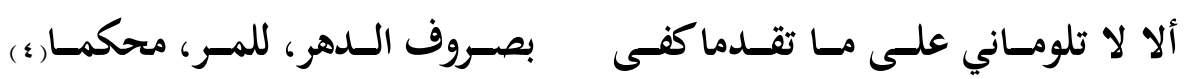

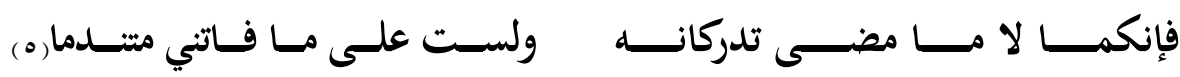

\section{المعنى}

يتحدث " حاتم" عن نفسه " بالغيبة " والعموم وذلك للتعظيم فأتى في هذه المقطوعة بألفاظ يغلب عليها أنها لعموم سائر البشر وعبر بالغيبة لأنه لا يربد التأكيد على ذاتيته أو نفسه بل العموم وسائر البشر يقول بعد هجعة من الليل 
=

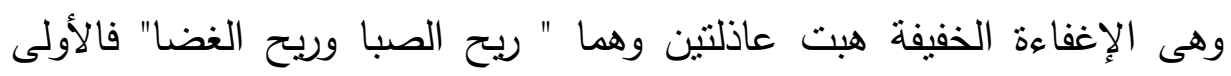

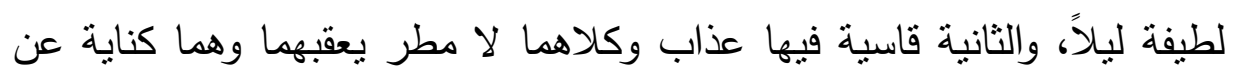

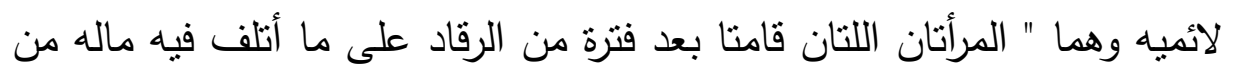

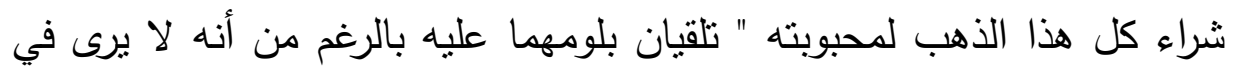

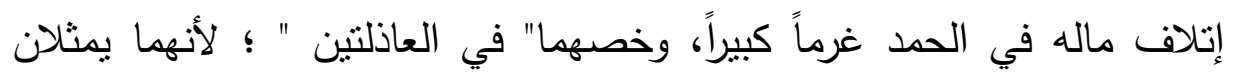

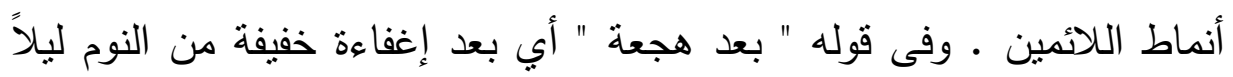

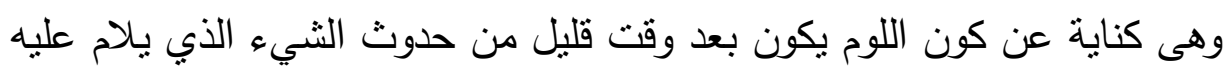

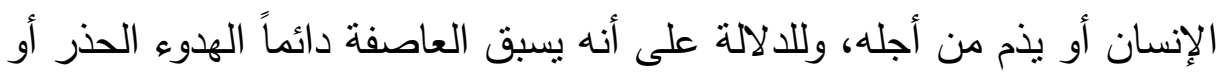
المقلق .

ولما أراد " الطائي " لصورته البلاغية أن تخرج في أكمل معنى وأتمه،

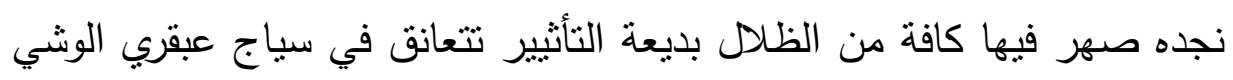

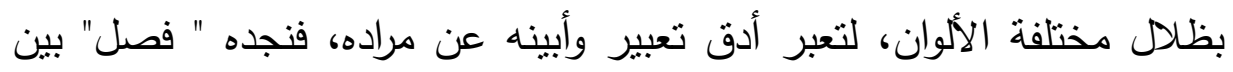
شطري البيت .

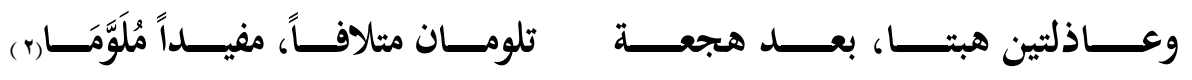

حيث فصل الجملة الثانية " تلومان متلافاً، مفيداً، مُلَوَّماً" جواباً عن سؤال

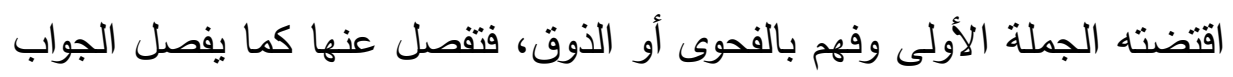
عن السؤال ويسمى هذا الفصل " استئنافاً " وكذلك تسمى الجملة الثانية " استئنافاً

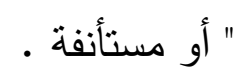

وهذا لغرض بلاغي وهو " شبه كمال الاتصال "

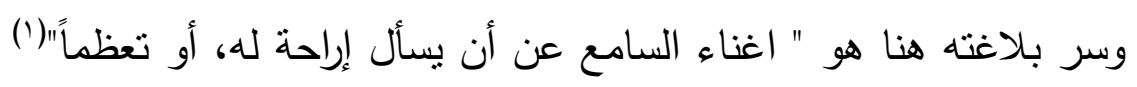
أو أن الثطر الثاني بياناً للأول وتفسيراً له . 


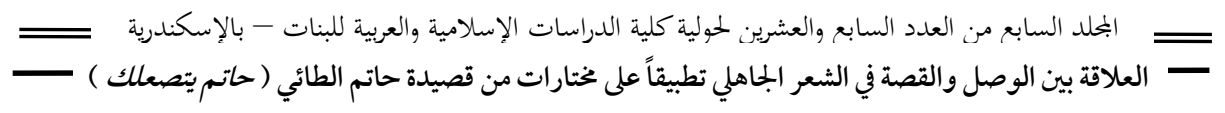

ولما كان هذا لا يفي بخصب خيال الثاعر وسعة أفقه نجده عمد بنا إلى الى الثيل

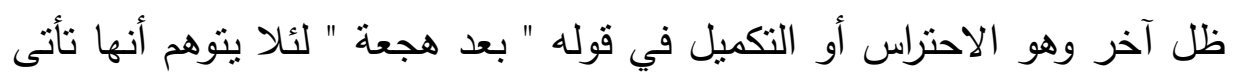

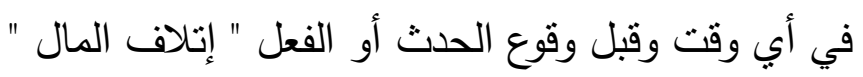

ولما كانت هي لا تلوم إلا بعد وقوع الفعل ناسبه التعبير " بالهجعة " لأنها

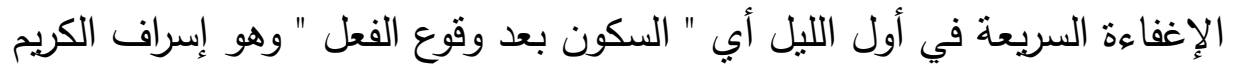

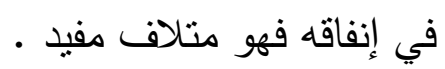

ولما كان الكريم لا يتوانى عن إنفاقه ناسبه التعبير بصيغة المبالغة " متلافاً

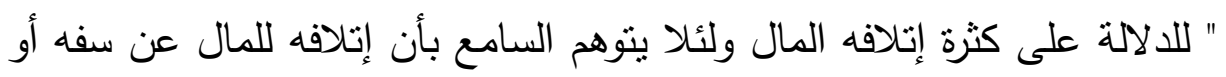

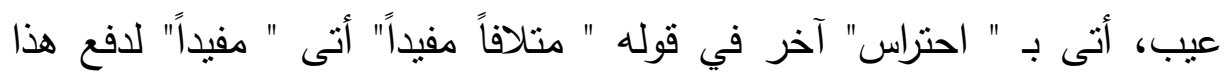

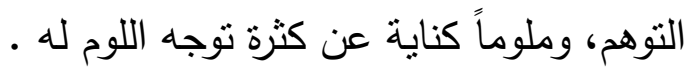

ئوقيمته هنا هو شدة التأكيد على مراده ولنتأمل سوياً هذا البيت حيث

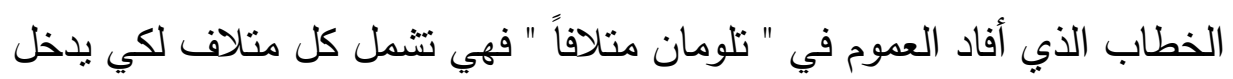

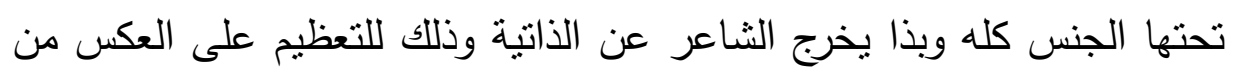

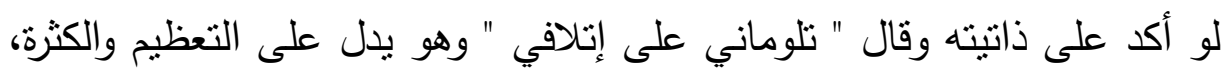

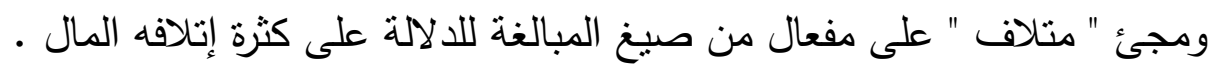
ومجئ " مُلَوَّمَاً" على مُفَعَّل بتضعيف العين للالالة على كثرة اللوم، ... هذا، ولم يأت بضمير التكلم ولم يشر إلى نفسه في هذين البيتين بحيث اختقت

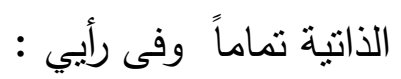

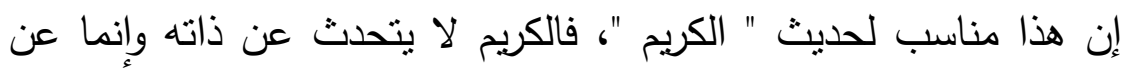

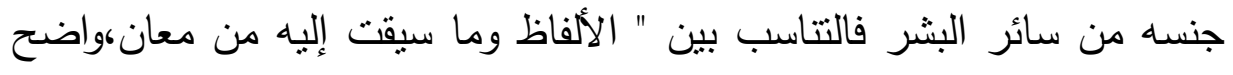

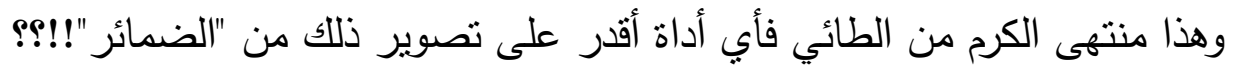

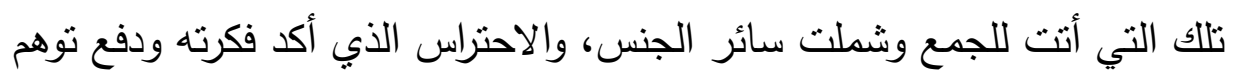


خلاف تشتطيع أن نقول إن " الطائي " كريم حتى في صوغه الثعر على هذا

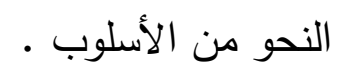

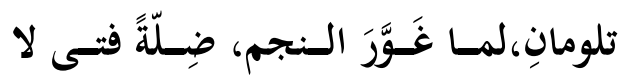

يــرى الإتــلاف، فـي الحمــدِ، مغرمــا

الحديث موصول مع العاذلتين الملوحتني، والخطاب عام يشمل كل أحد يقول " لما غور النجم " أبي مال إلى الغروب حيث " غَوّرَ" أي بدأ في الإختفاء من غار النجم يغور ودلالنه أنه لما كان الإنفاق في الغالب لا يكون إلا ليلاً حيث السرية والخفاء، ناسبه التعبير عن ذلك بـ " غور النجم "، وهى كناية لطيفة عن اللوم ليلاً؛ لأنه في الغالب يكون الإنفاق ليلاً ومنها إلى الكرم فهي كناية

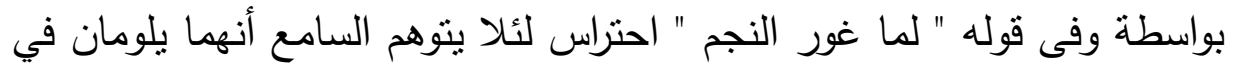

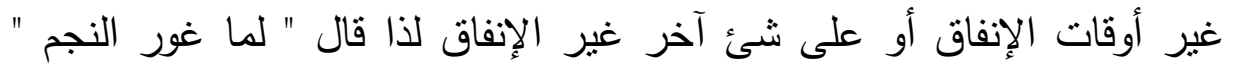

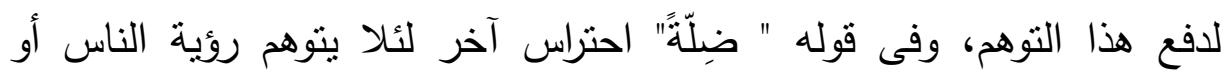

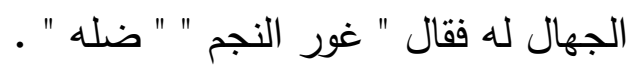

ولو لم يذكرها الثاعر لتوهم السامع أن الإنفاق عند الغروب وفى وجود

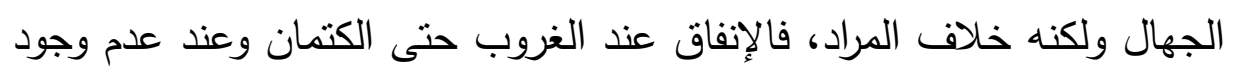

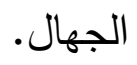

فالثاعر موفق في اختيار ألفاظه، مما بدل على سعة أفقه وخصب خياله

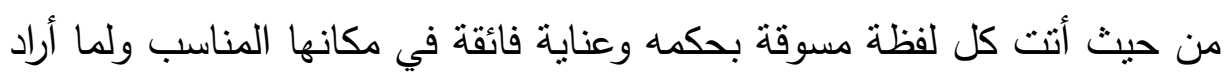
" حاتم " التأكيد على أسلوبه في توجيه الخطاب وصوغ الأسلوب ناسبه التعبير عن ذلك أيضاً بتتكير لفظ " فتى " لصون اللسان عن ذكره تعظيماً له، فهو فئه يناسب أسلوب التعظيم الذي صاغ به حاتم الطائي أبياته عليه، فهو موفق في اختيار ألفاظه من حيث صوغها على هذا النحو من الدقة وجودة الصياغة، هذا بله ولجأ الثاعر إلى التعبير بالأفعال المضارعة في هذين البيتين حيث

$$
\text { " تلومان - تلومان - غَوَّرَ - برى - تلاف " }
$$




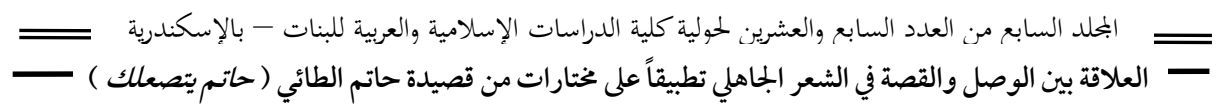

لأنها تصور الحركة من هبوب للوم - ميل للغروب - استمرار في إتلاف،

وهو أمر طبيعي فمعظم الصور التي تمثل الحركة والتحول تكون الجملة الفعلية خير عون في هذا المضمار فهو يوظفها لخدمة اللوحة أو الصورة .

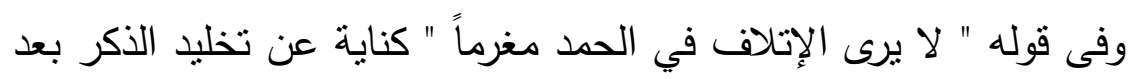

الرحيل " الذكرى الطيبة " ولما كانت الكناية تحمل الدعوى مع دليها أو في لإني

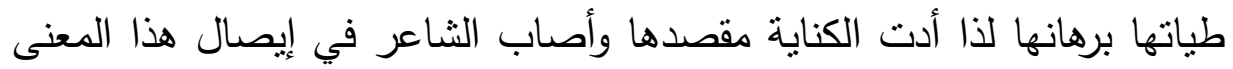
بذات الصورة إلى ذهن القارئ، مع ما فيها من مبالغة مقبولة لتحرك خيال القارئ، هذا والصورة الفنية ليست إلا نسيجاً نشدُ خيوطه بعضه بعضاً فئه في نتاغم وأصالة، ومن هنا تتعامل مع نظم الصورة وليس مع مفرداتها اللغوية، فهنا تشكيل رائع أقدم عليه ( الطائي ) وهو " التكرار " من حيث تكرار الفعل ومشتقاته

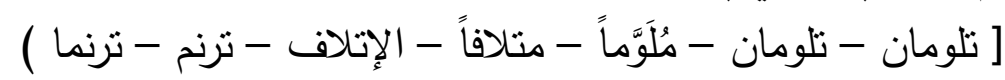

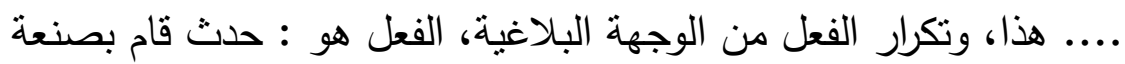

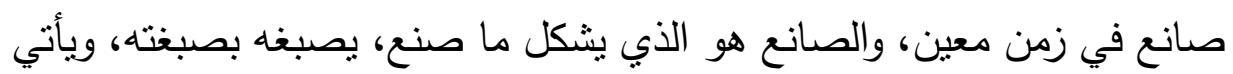
الزمن ليضيف أثراً خارجياً يتغير بتغيرِ وقوعه ماضياً كان أو حاضراً أو مستقبلاً

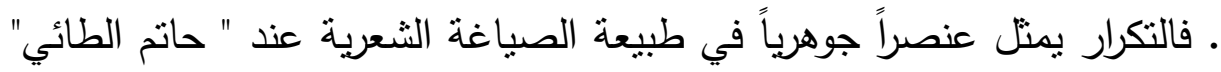
حيث يتوسل به في تشكيل صورة ليؤدى وظائف عديدة، أسهمت بدورها في إبراز موقفه الفني،

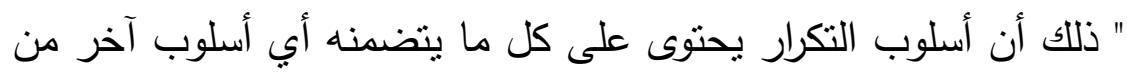

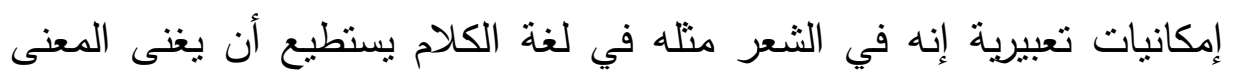
ويرفعه إلى مرنبة الأصالة، ذلك إن استطاع أن يسيطر عليه سيطرة كاملة

ويستخدمه في موضعه " (').

وقد تتوعت صور التكرار في قصيدته فجاءت على مستويات عدة وهى موقى تكرار الكلمة وإشتقاقتها كما في البيت الثالث " غيرت - غيرها - غيرن وتكرار

(1) نـازك الملائكـة : قضـايا الثـعر المعاصـر، دار العلم " السـابقة " بيروت بم9 ام ص " 
=

الكلمة وإثتقاقتها كما في البيت الساد والثامن " هبت هبنا " وتكرار الحرف

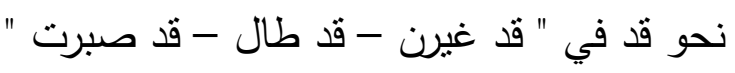

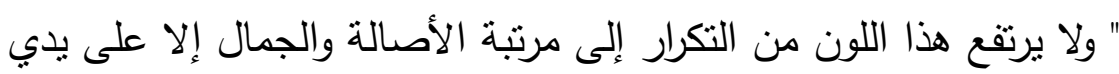

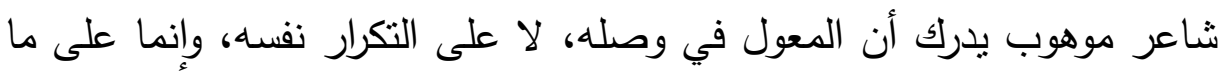

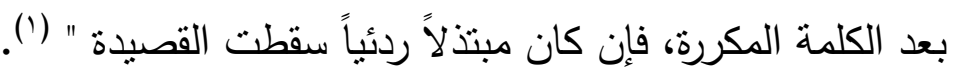

وفى رأيي : إن التكرار يؤدى وظيفته بشكل أمثل حين تتكرر الكلمة بشرط

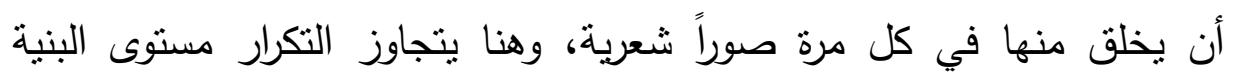

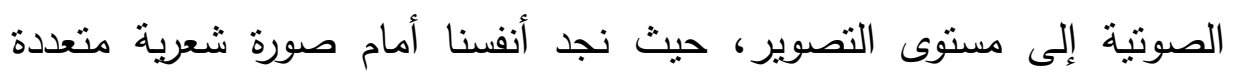

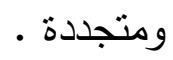

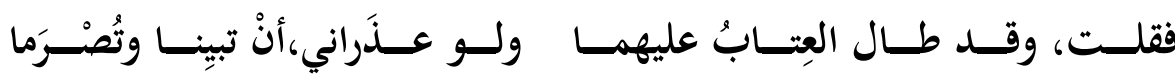

المعنى : الحديث موصول عن اللوم أو العاذلتين اللائمتين . يقول لقد

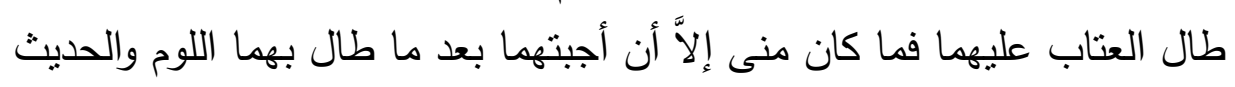

وقلت كفاكما لوماً وعتاباً على ما قدمت يداي، فالدهر خير حاكم على فعل

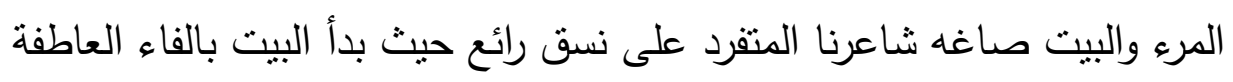

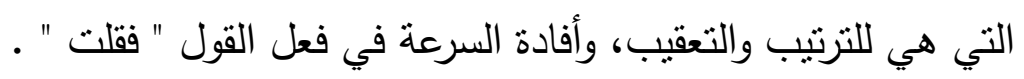
لنبدأ بالوصل وسر المجئ :

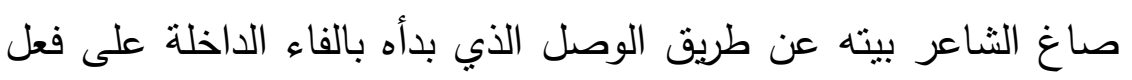

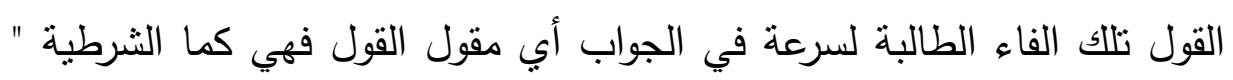

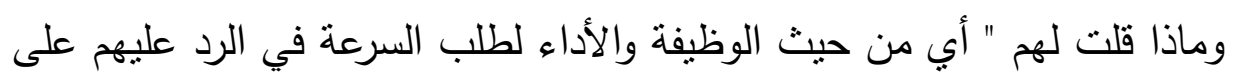

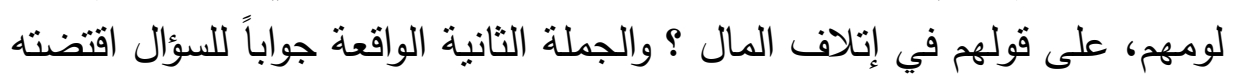

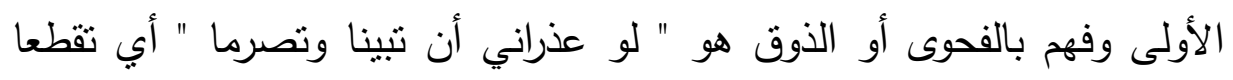

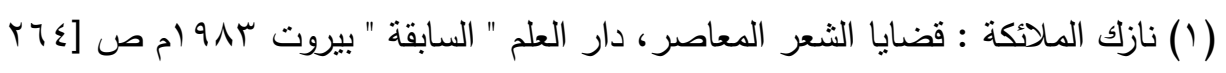




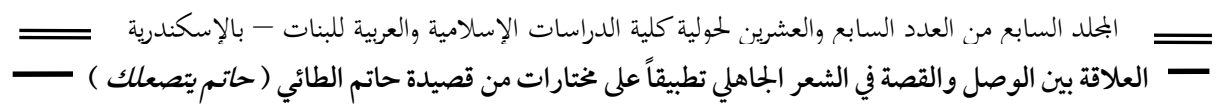

العلاقة به و تتركاه وأتى بجملة " وقد طال العتاب عليهما " حالية أي الهيئة والحال التي كان عليها القول، وقوله : لو عذراني أن تبينا وتصرما " جملة مقول لتهل

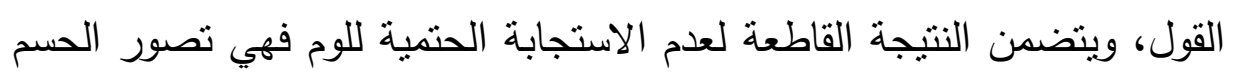

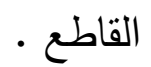

هذا، وفى قوله " أطال العتاب عليهما " التفات من المتكلم أي " فقلت " إلى الغيبة في قوله " وقد أطال العتاب عليهما " .

وقد صاغ هذه الجملة على نسق بديع من حيث مجئ الواو التي هي

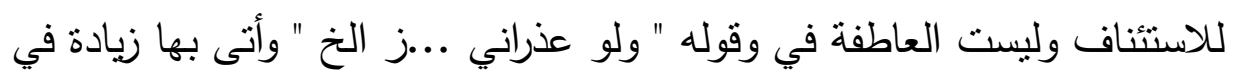
التوضيح والتفسير • وتبعها " قد " التحقيقية الداخلة على الماضي في " طال " أي هيئة طول اللوم التي يصير عليها الثاعر وكون الفعل ماضياً يفيد تحقيق وقوعه كما يقول البلاغيون وإضفاء صفة الدوام مهما اختلفت رؤى المخاطبين

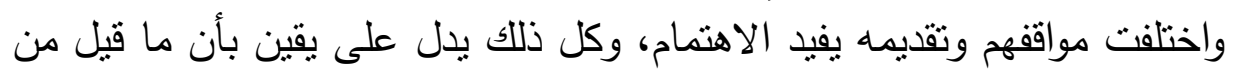

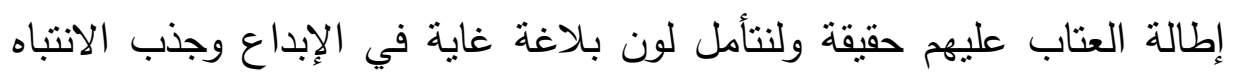

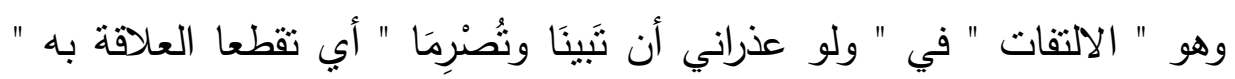

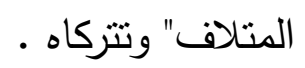

إن الالتفات في العربية اختصت به دون غيرها من اللغات يقول أبن الأثير

في المنث السائر : - 20

" وقد أحسن الزمخشرى الكلام عن سر بلاغة الالتفات فقرر أن الرجوع

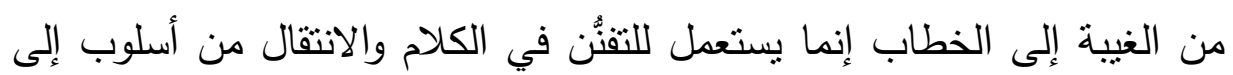

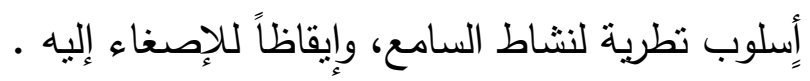
يقول د/ بدوى طبانة في كتابه معجم البلاغة العربية

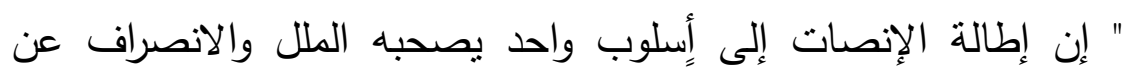
المتكلم، والمغايرة في الأسلوب تجديداً لنشاط السامع، وكذلك المغايرة في المعاني • وهناك دواع أخرى غير هذا الأمر، فقد يكون من أسبابه تعظيم شأن المخاطب 
=

بالتوجيه إليه، أو الانصراف عنه، أو تكذيب القول بعد روايته، وتتبيه السامع إلى ما فيه من الخطأ " (1).

وفى رأيي : قد ظهرت تلاك المغايرة في الانتقال من الفعل المبنى للمعلوم

للمجهول .

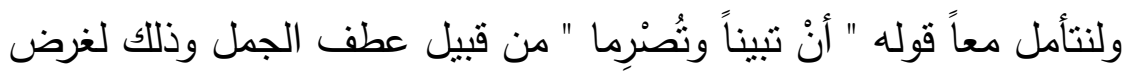

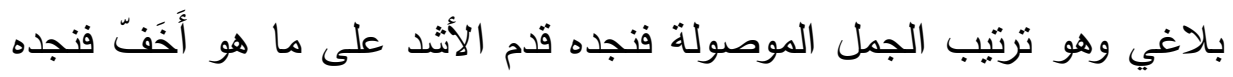

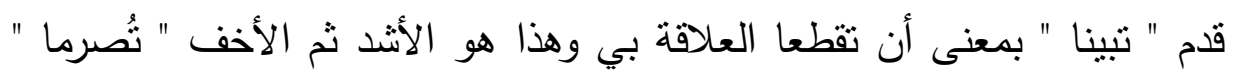

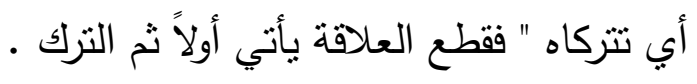

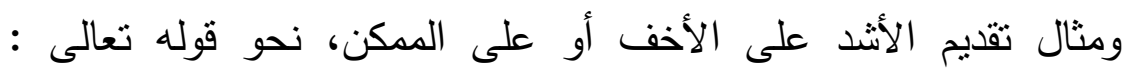

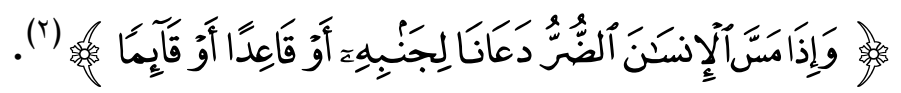

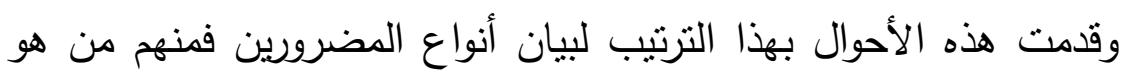

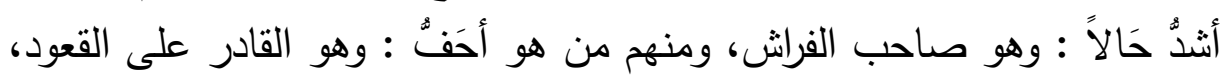

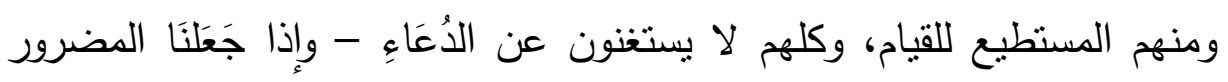

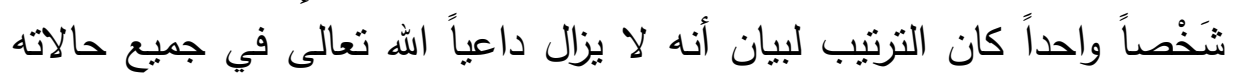

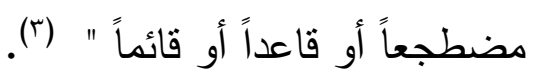

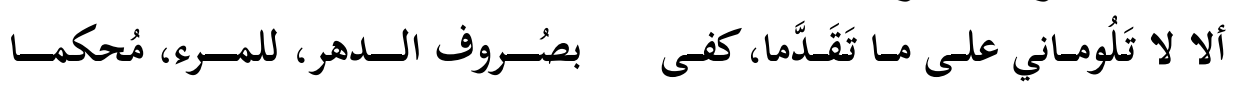

المعنى : يطلب الثاعر من اللائمان على ما تقدما من الإنفاق ويقول :

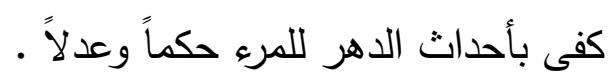

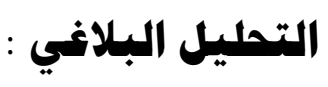

(1) د/ بدوى طبانة - دار المنارة جده - دار ابن حزم بيروت - الطبعة الرابعة 199 ل 19 - ص

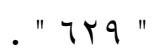

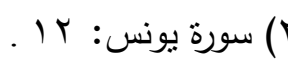

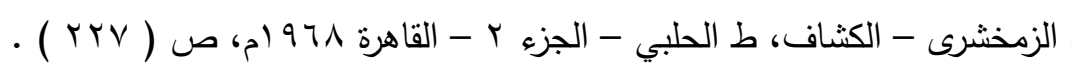




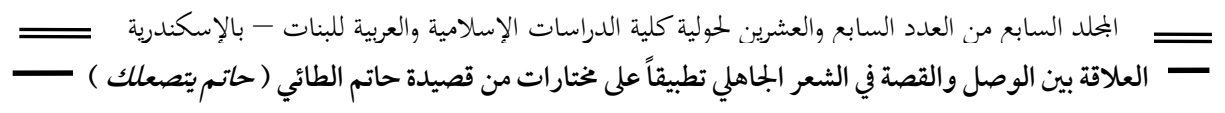

بدء البيت " بألاً بفتح الهمزة والتخفيف "؛ للتنبيه، فتدل على تحقق ما

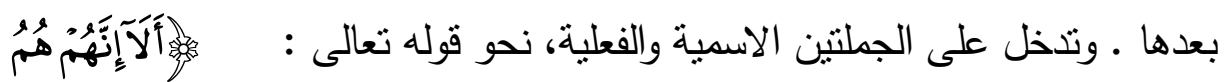

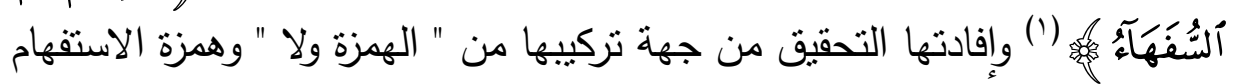

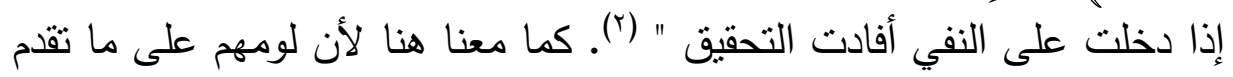
حقيقي وآكد والسر البلاغي في ذلك هو جذب انتباه السامع لما يلقى من كلام غاية في الأهمية

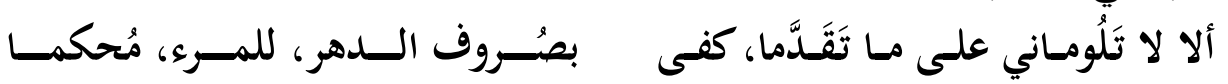

البيت لوحة بيانية رائعة التصوير من الاستعارة حيث نحا به منحى آخر

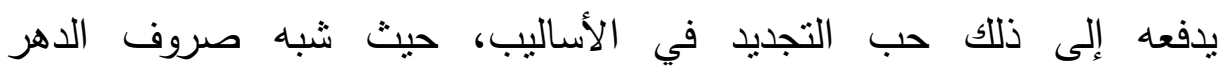

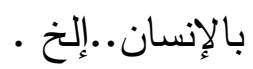

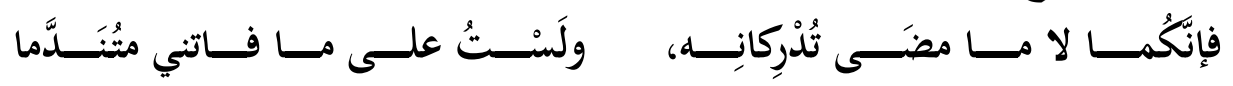
المعنى : يقول حاتم أنا لست على ما فاتتي متتدما لأنكما تدركان ما

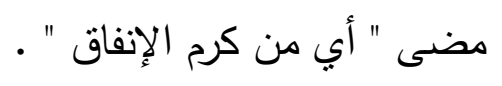

لنبدأ بالوصل في البيت : حيث نجد " الطائي " ربط البيت بوثاق متين عن طريق العطف بالواو وذلك لغرض بلاغي وهو كمال الاتصال، فالجملة الثانية

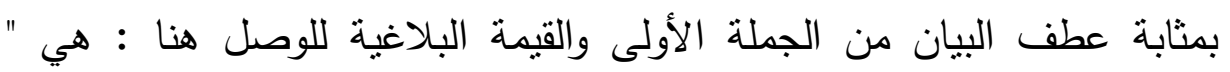

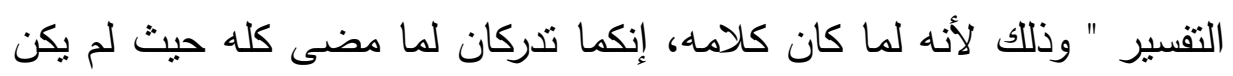
فيه ما يقدح بسبيه أو يذم فكله كرم وإنفاق فتكون النتيجة لذلك أنه ليس متتدماً

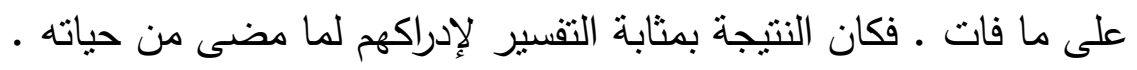




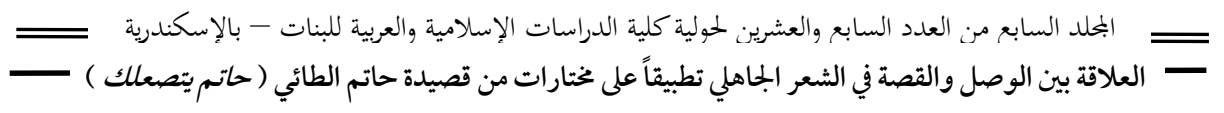

ومما يدلل على الغرض من أن الوصل أتى للتفسير نحو قوله تعالى

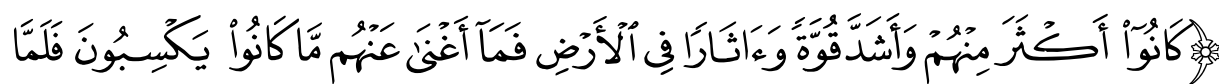

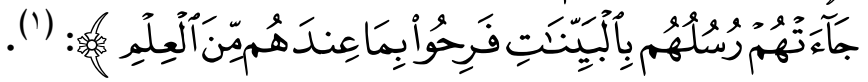

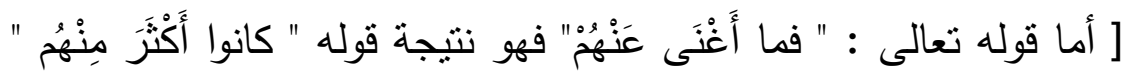

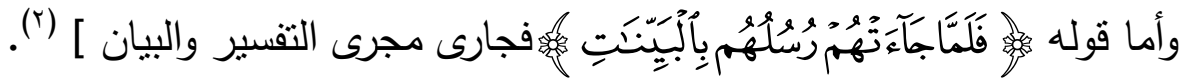
أمَّا في هذا البيت نلمح بداية تأكيد " حاتم الطائي" على ذاتيته في قول

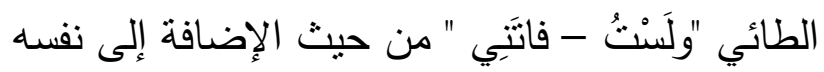

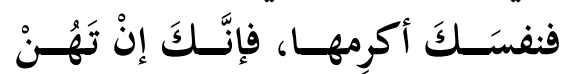

عليـكَ فلـن تُلفـى لـك الـدهرَ، مُكرِمـا

المعنى : يأمر " الطائي" الإنسان على سبيل النصح والإرشاد بأن يكرم

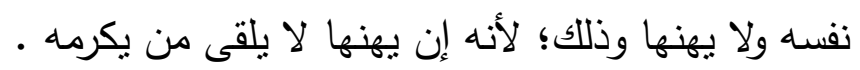

الفصل والوصل في البيت : نجد الطائي صور تلك النصيحة عن طريق " الفصل" وذلك لغرض بلاغي وهو " شبه كمال الاتصال" حيث وقعت الجملة الثانية وهى " إن تهن عليك فلن تلفى للك الدهر، مُكْرِما " جواباً لسؤال فهم بالفحوى أو الذوق، وهذا السؤال هو " لماذا أكرمها ؟ "أو ما الداعي إلى إكرامها،

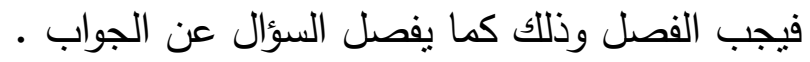
هذا .. ، والذي يأخذ بالألباب ويجذب القلوب هو السر من لجوء الطائي

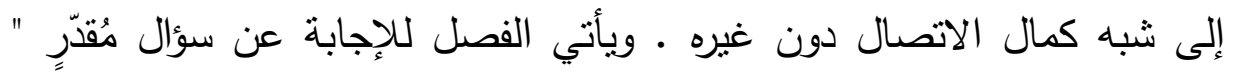
الاستئناف " .

ويسمى الاستئناف البياني، يقول: الزمخشري في غرض الفصل لشبه كمال

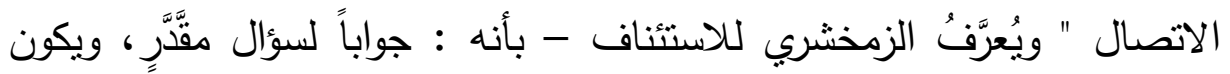

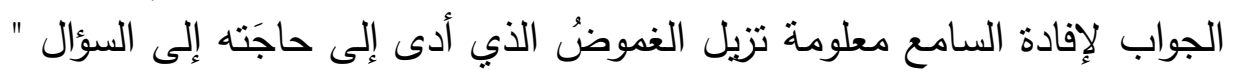

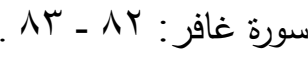

$$
\begin{aligned}
& \text { الزمخشرى : الكثاف - الجزء الأول ( سبق ذكره ) - ص (ror) . (Y) . }
\end{aligned}
$$


(') وقد " يخرج من هذا الإطار إلى أغراض أخرى بأن يجاب عن السؤال بما

$$
\begin{aligned}
& \text { يفيد . } \\
& \text { - - التعليل أو - } \\
& \text { - - - التعجب أو التعلي } \\
& \text { - } \\
& \text { - بيان السبب " (؟) }
\end{aligned}
$$

وفى بيت " حاتم الطائي " خرج الاستئناف لبيان السبب أي سبب الإكرام "

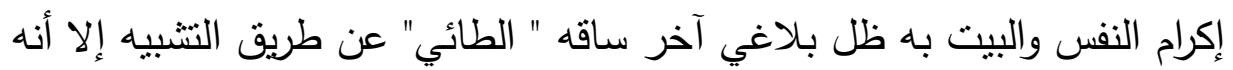

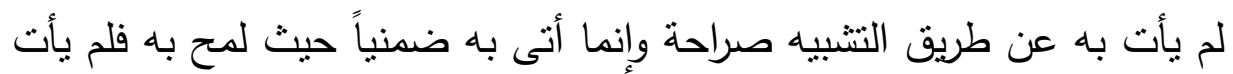
بالمشبه ولا بالمشبه به وإنما كان ، الثطر الأول من البيت بمثابة الدعوى والآخر

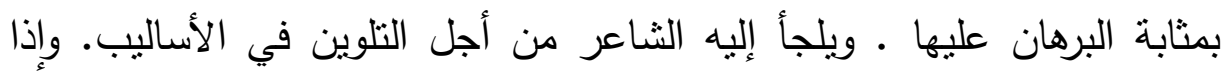
تأملنا إيحاءات الألفاظ والحروف ودلالاتها نجد " الفاء" الثانية في قوله " فإنك " داخله على أسلوب الثرط وفى هذا التركيب الذي وجدت به ما بدعو للفكر فنجد

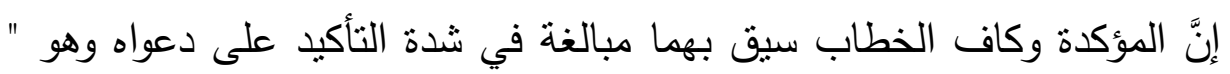
هَوْنُ النفس " فأي حرف يستطيع أن بقوم بما قامت بهاته " الفاء" عنا من حيث

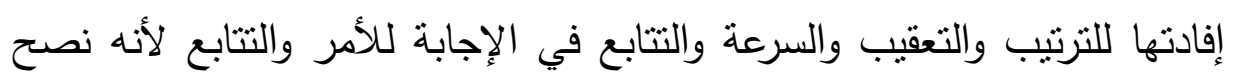

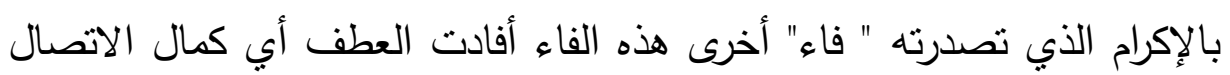
بين هذا البيت والسابق عليه . بالِكرم

والفاء في " فإنَّكَ إنْ تَهُنْ " على هذا التركيب داخله على ما هو في قوة

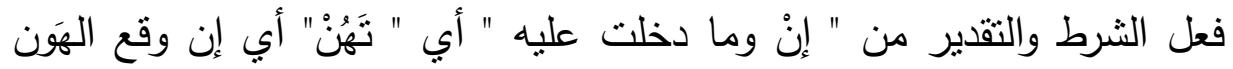

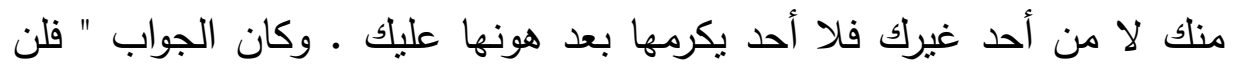

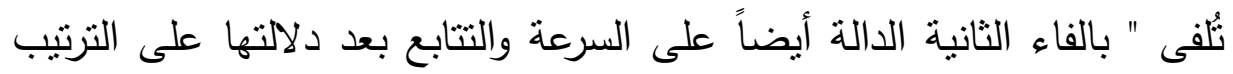
والتعقيب الواضحين " وعليك " توسطت بين فعل الثرط وجوابه " فلن تُلفى للك "

(1) الزمخشري : الكثاف ( سبق ذكره ) الجزء الثناني - ص (•9 (Y) .

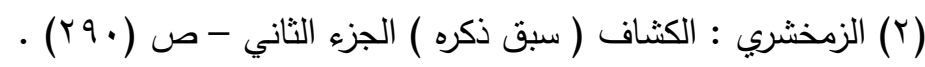


=

للتأكيد على ذاتية المخاطب بأنه هو وحده إن لم يُعز نفسه لم يُعزهها أحد غيره

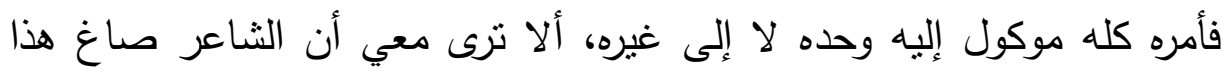

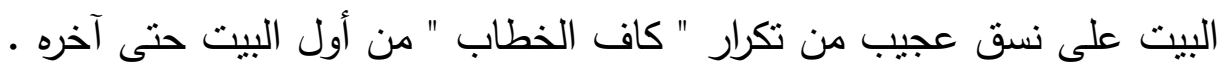

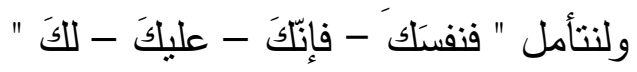

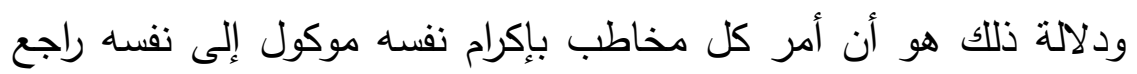

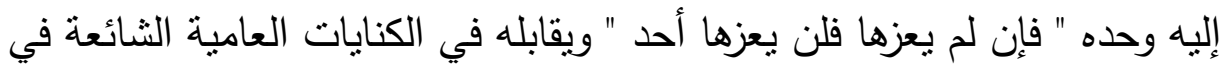

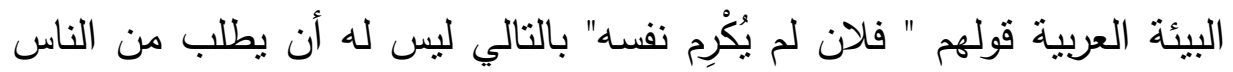

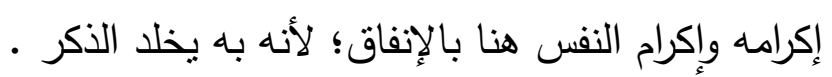
والحديث موصول مع المخاطب المتخيل ( المستصح ) من الثاعر ثم

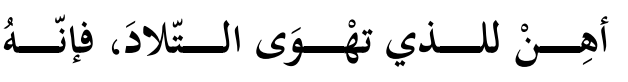

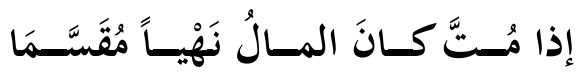

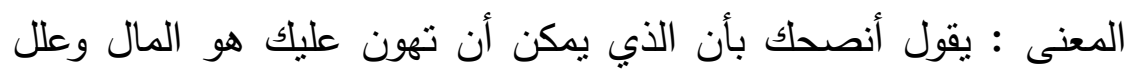

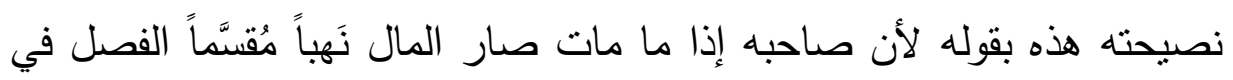

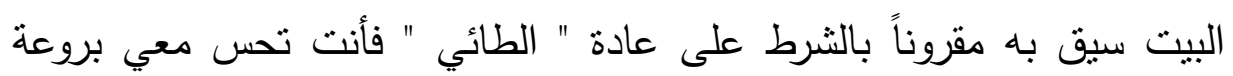

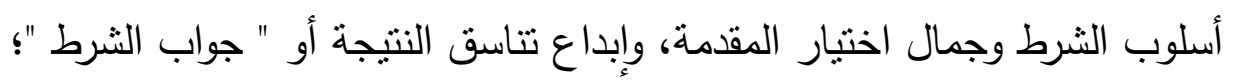

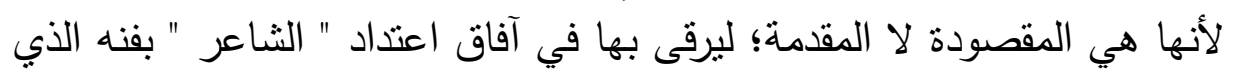

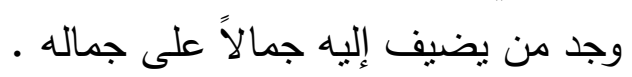

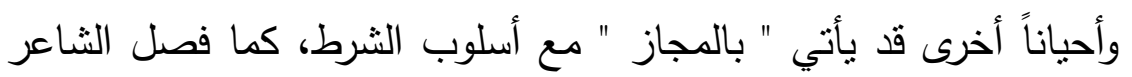

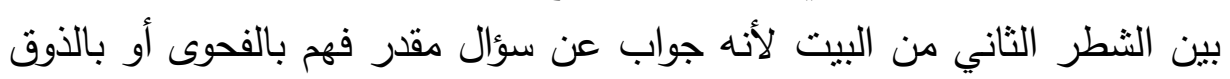

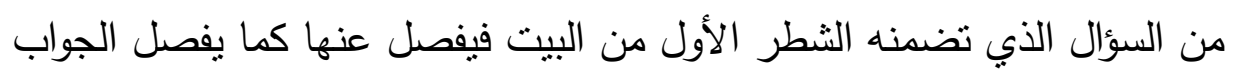

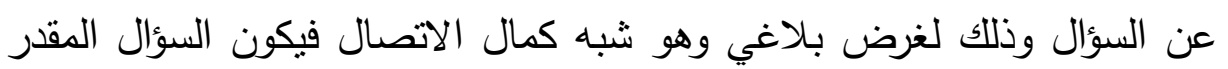

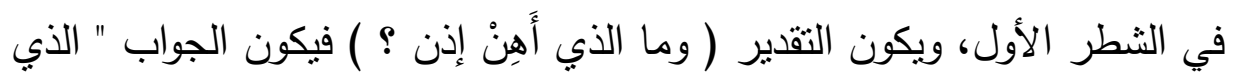

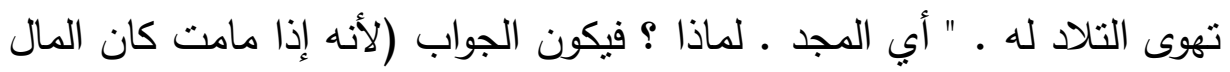




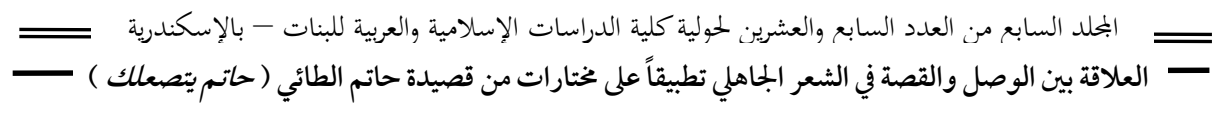

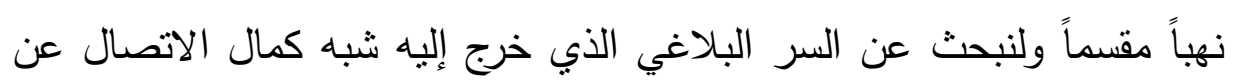

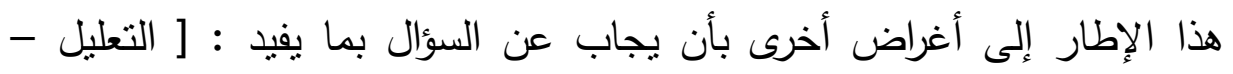
التعجب - التأكيد - بيان السبب ] والاستئناف لبيان السبب وحقارة المنفق " المال

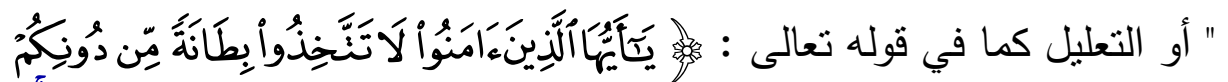

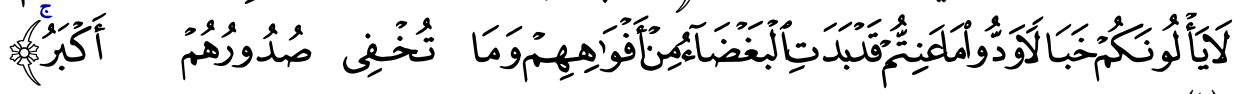

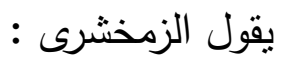

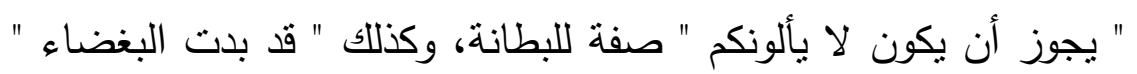

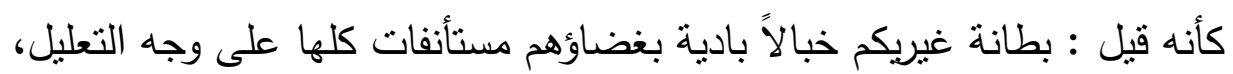

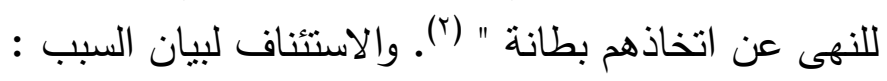

كما في قوله تعالى

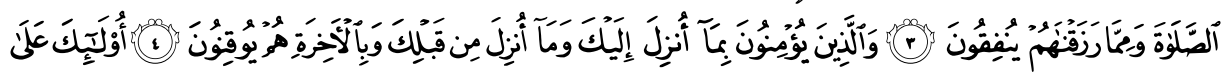

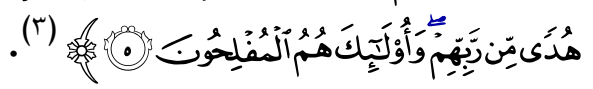

يقول الزمخشرى : " الجملة في محل رفع إن كان " الذين يؤمنون بالغيب "

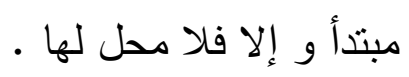

ونظم الكلام على الوجهين : أنك إذ نويت الابتداء بالذين يؤمنون بالغيب،

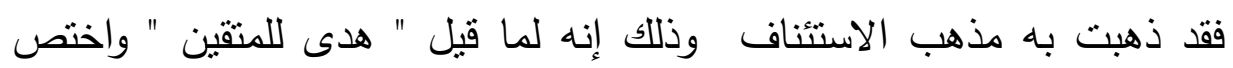

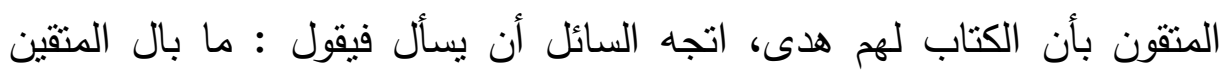

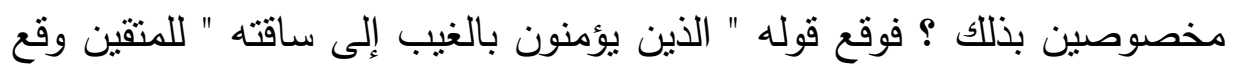

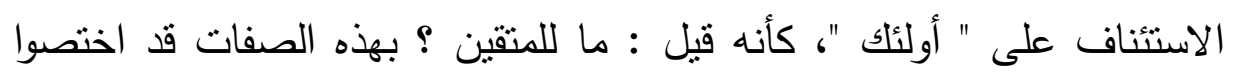

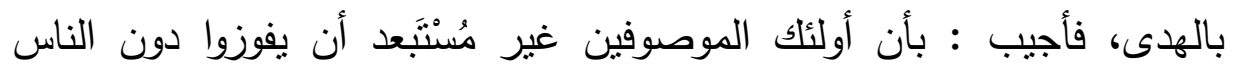

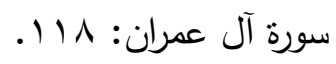

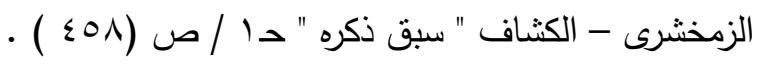

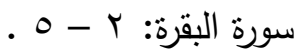




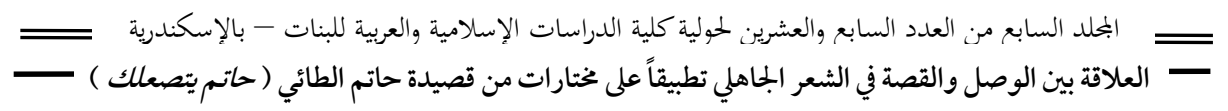

بالهدى عاجلاً وبالفلاح آجلاً . واعلم أن هذا النوع من الاستئناف يجئ تارة

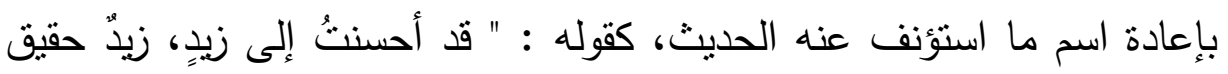

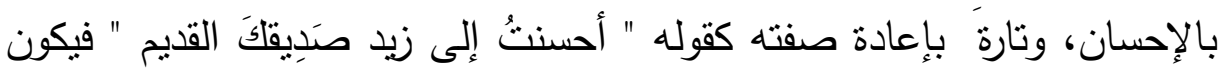

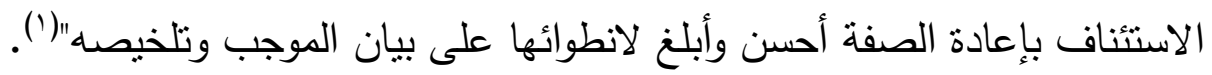
. هذا،

وإذا ما تتبعنا إيحاءات الألفاظ ودلالاتها نجدها على النحو التالي :

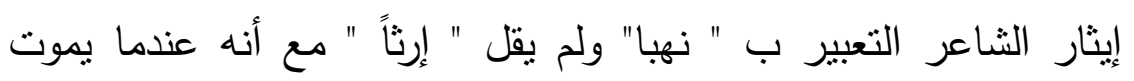
الإنسان تتحول أمواله إلى إرث، وللإجابة على ذلك نقول إنه لما كان المال حقيراً

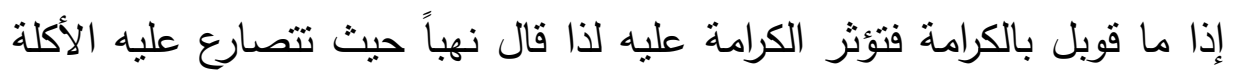

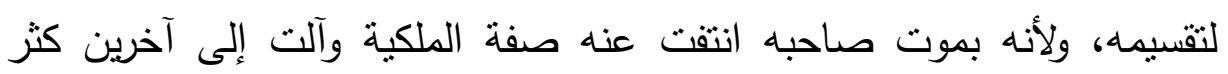
تقاسمونه نهبا بينهم، أو لأن المال إذا نتازعته أياد كثيرة صار كالنهب بتهبه بتقاسمونه

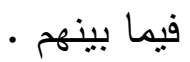

والثاعر موفق تمام التوفيق في اختيار ألفاظه؛ فكلها بارعة في موضعها الذي قصد بها إليه مصورة أتم تصوير وأبينه . ولما كان هذا لا يفي بخصب خيال الطائي وسعة أفقه، نجده عمد بنا إلى ظل آخر جمل به لوحته البلاغية؛ لكي تتبارى بألوان وظلان خرج بهان بها إلى إلى

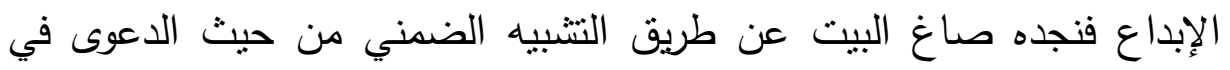
"أهن الذي تهوى التلاد " والبرهان عليها في " لأنه إذا مت كان نهاء لهاً مقسماً " وقوله " المال نهباً " هو الذي لا يتعب فيه الناهب ولا يعانى في جمعه . ...هذا، ويقابله في الكنايات العامية الثائعة في البيئة المصرية " مال

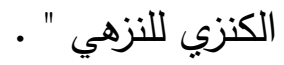

والحديث موصول مع المال وما يجب أن يفعله الإنسان، يقول الطائي :

$$
\text { (1) الزمخشرى - الكثاف " سبق ذكره " حـ / ص ( (1 ا - . . 1 ) . }
$$




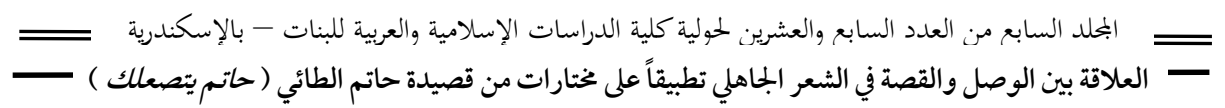

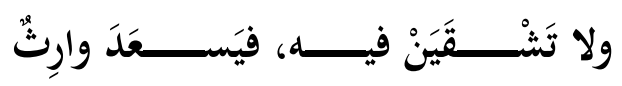

بـه، حين تخشى أغبر اللّوْنِ مُظلمـا ( )

المعنى : الحديث موصول عن المال الذي يؤول بعد الموت إلى آخرين

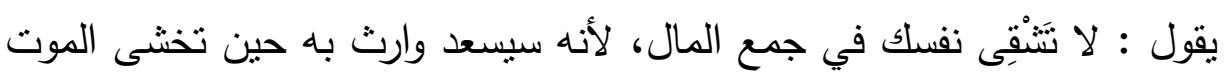

لنبدأ بالفصل والوصل، فصل الثاعر في كلامه بين طرفي البيت وذلك لغرض بلاغي وهو شبه كمال الاتصال؛ لأن الجملة الثانية كانت بمثابة الجواب لسؤال اقتضته الجملة الأولى، ودلت عليه بالفحوى أو بالذوق فيكون ثقدير السؤال

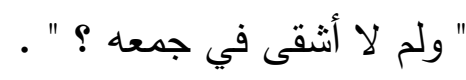

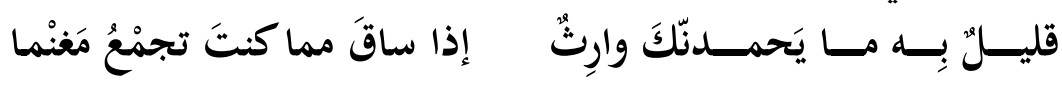

المعنى : الحديث موصول مع المال، يقول الطائي : لا يحمدنك وارث على هذا المال، وإذا حمدوك فهم قليل، ولاسيما عندما يسوقونه مغنماً . بدأ

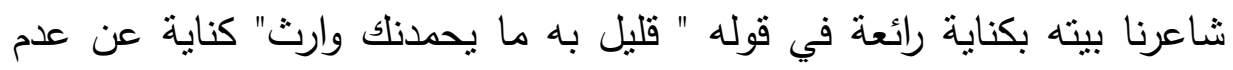
ذكر محاسنه، أو فضائله فهر عندما يحصلون على فئل " المال " سريعوا النسيان لصاحبه . دكر مله

ونلمح روعة أسلوب الثرط في قوله " إذا ساق مما كنت تجمع مغنما "

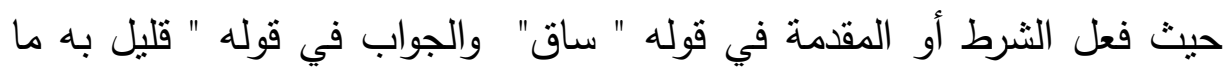

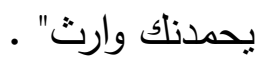

وقدم الجواب على الثرط بقصد تصوير ما جرت عليه الطبائع البشرية " فهو لا خلاف عليه " أو تقديم الأسرع وروداً إلى النفس حيث جرت جرت به به العادة وعليه جبلت الطبائع البشرية .

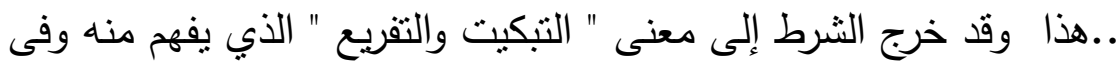
قوله " إذا ساق مما كنت تجمع مغنماً " استعارة مكنية حيث شبه المال الموروث بما بساق من البهائم أو الدواب عموماً ثم حذف المشبه به " الماثية أو الدواب " 
=

وأبقى على ذكر لازم من لوازمه وهو " ساق" من السوق وهو سهولة الانقياد أي لئي

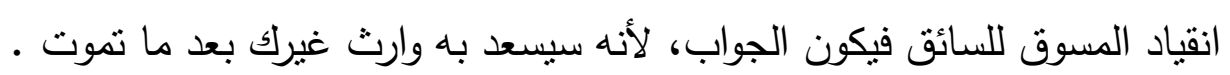

والسر البلاغي الذي اقتضاه مجئ الاستئناف هنا هو " لبيان السبب "

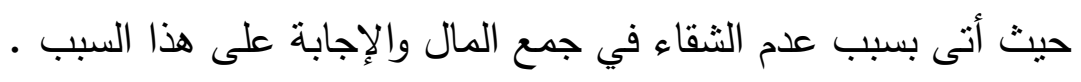
وذكر استدلال الزمخشرى على ذلك في الكثاف سابقاً .

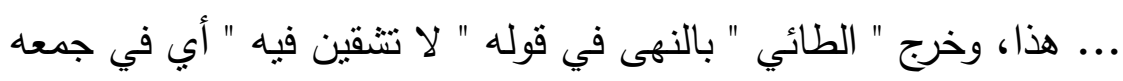

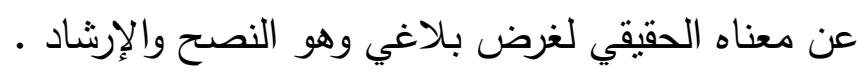

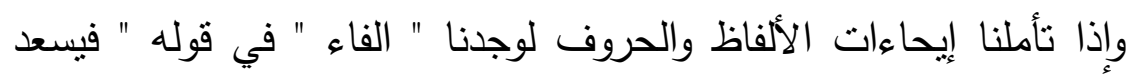

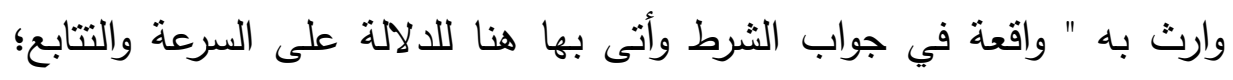

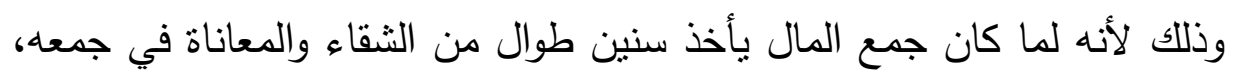

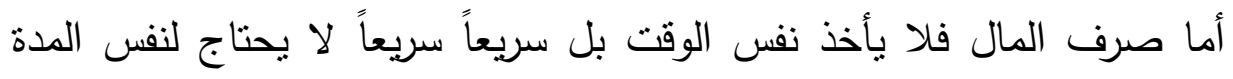

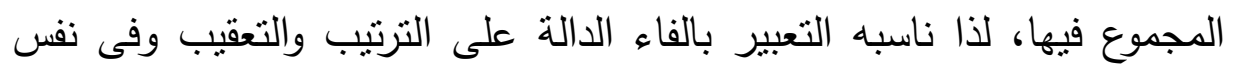

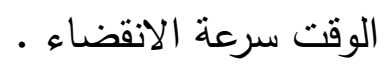

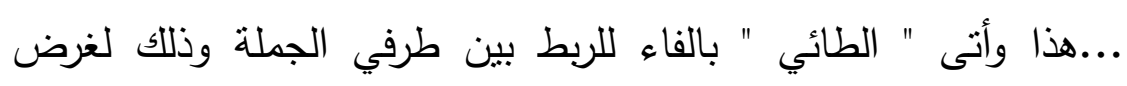
بلاغي وهو شبه كمال الاتصال .

وفى قوله " به " إيجاز بالحذف، والمحذوف " كلمة " وتقديرها " فيسعد

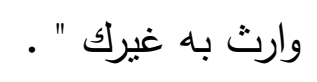

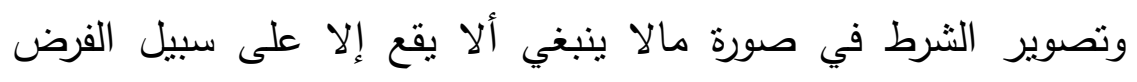

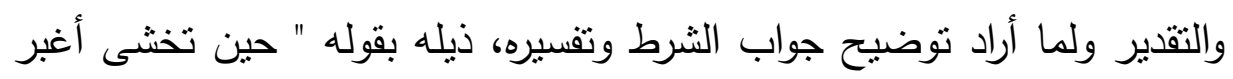

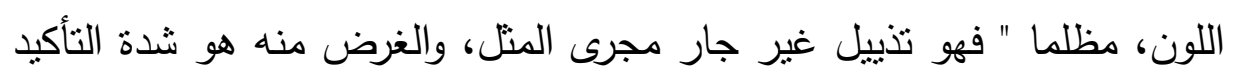

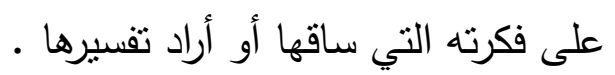

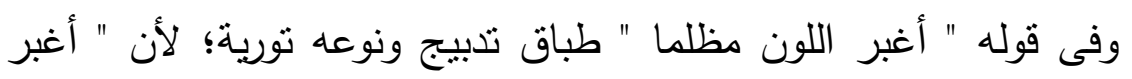

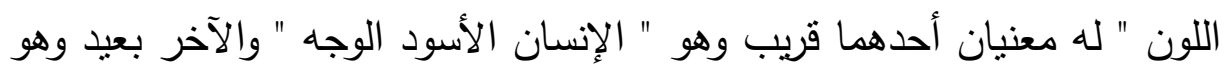

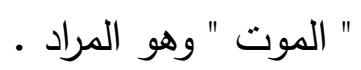




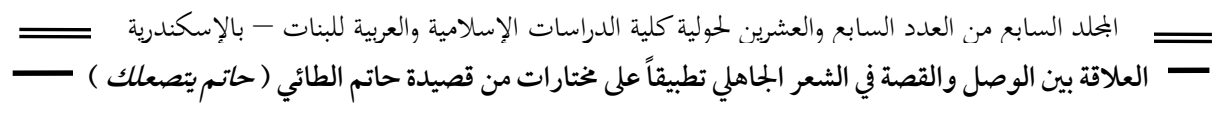

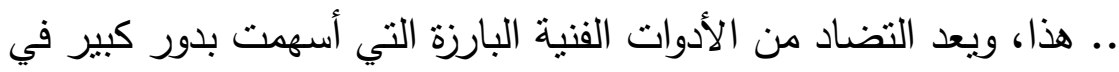

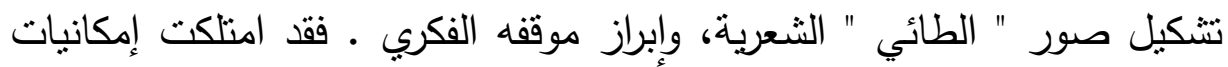

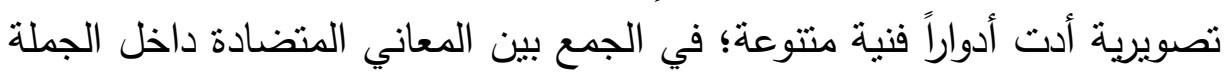

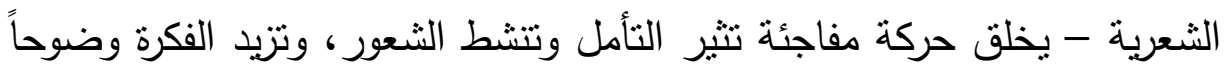

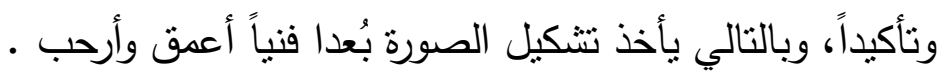

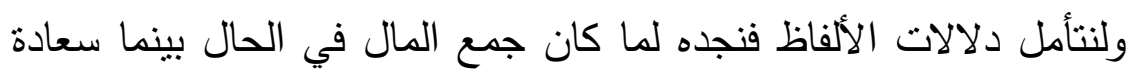

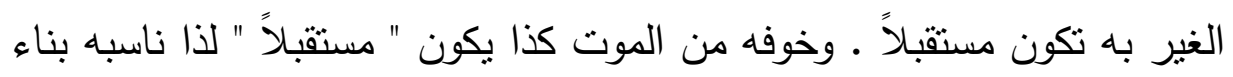

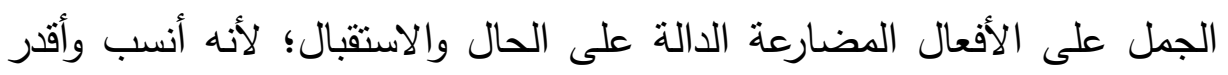

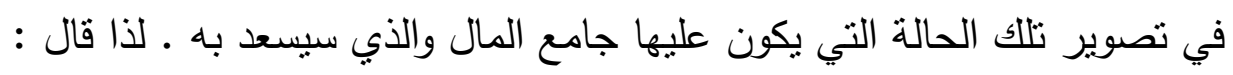

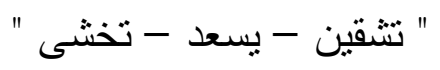

وبهذا استطاع " الطائي " أن يوظف المفردات اللغوية؛ لتحمل دلالات

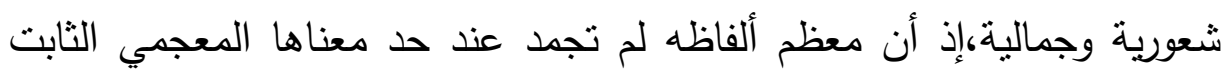

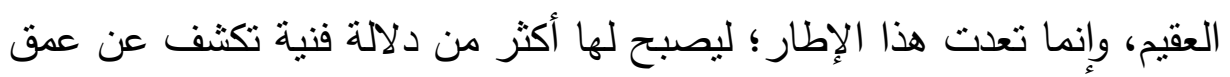

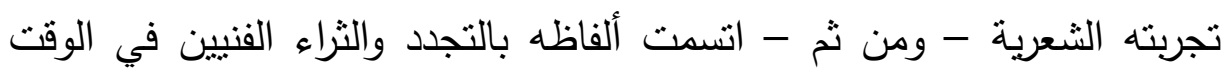

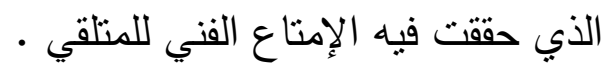

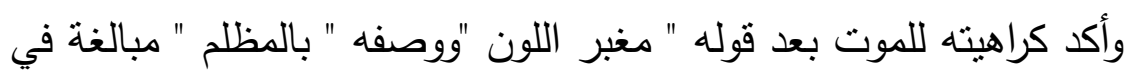

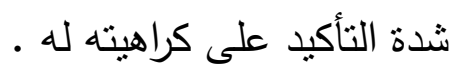

والحديث موصول عن هذا المال الموروث الذي يسعد به غير جامعه يقول

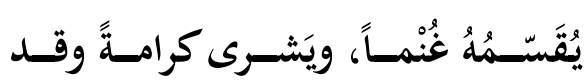

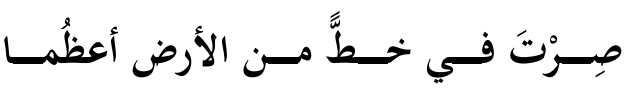

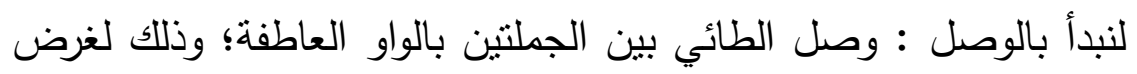

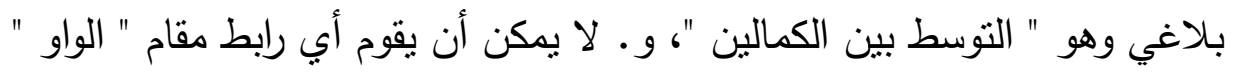




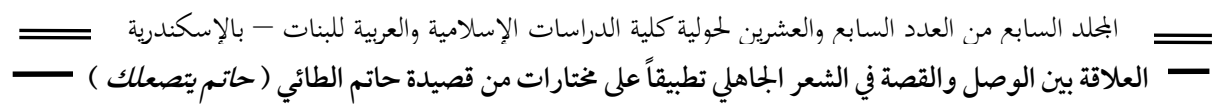

هنا لما لها من خصوصية الإطلاق فهي تربط بين الطرفين بلا ترثيب ولا تعقيب

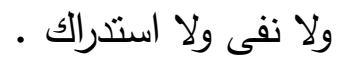

ولولا " الواو " لا نفصل عُرَى الربط بين الصورتين هذا، والجملتان خبريتان لفظاً ومعنى والتتاسب بينهما واضح من حيث أنهما يتعلقان " بتقسيم المال كالغنيمة وشراء الكرامة بعد موت صاحب المال، والجملة الفعلية خير عون في لئسي هذا المضمار ... هذا والجملتان متحدتان في الخبرية لفظاً ومعنى والمسند إليه فيهما واحد وهو " المال" والمسند فيهما واحد وهو " المخاطب "هنئ " العائد عليه

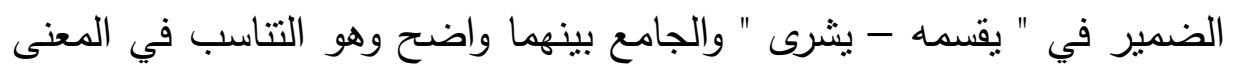
[ حيث التناسب في المضارعة ] " فمن يجعل المال نهباً مقسماً يقسمه كالغنيمة وتشري كرامة له له وخرج التوسط بين الكمالين هنا " لتقرير المعنى "

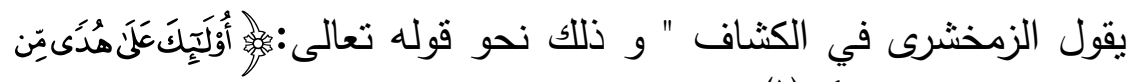

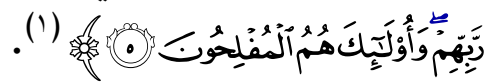

فكانت الجملة الثانية مقررةً لما في الأولى من العطف " (؟). فهو يتخذ المال نهباً و يقسمه كالغنيمة ويشري كرامة له . ولنتأمل قول الطائي " يقسمُ غُنماً" من التشبيه المفرد الطرفين المحذوف

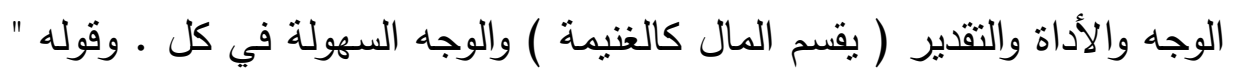
وقد صِرْتَ" في خط من الأرض أعظما " معطوفة على الثطر الأول من البيت "

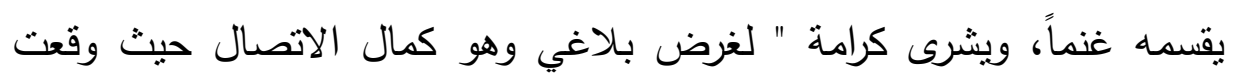
الجملة الثانية " عطف بيان من الأولى " . وسبب مجئ هذا الوصل كما يقول الزمخشرى في كثافه " ويأني الوصل

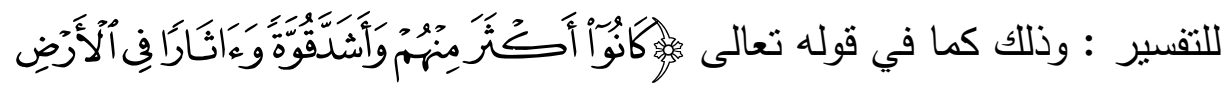




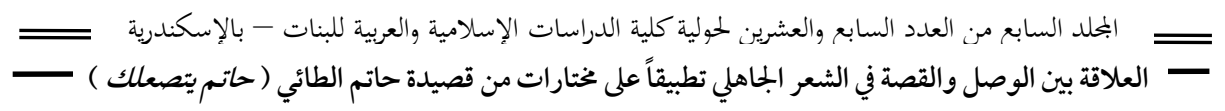

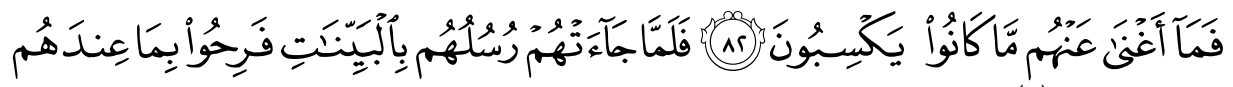

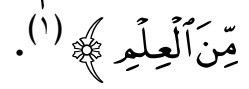

أما قوله تعالى " فما أغنى عنهم " فهو نتيجة قوله " كانوا أكثر منهم " وأما قوله " فلما جاءتهم رسلهم بالبينات " فجار مجرى البيان والتفسير لقوله تعالى : "

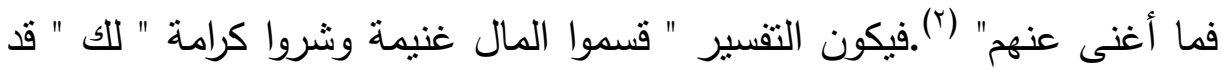

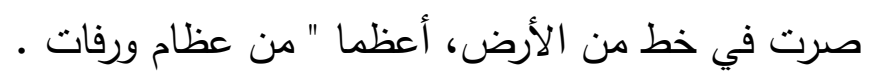
وإذا تأملنا إيحاءات الألفاظ نجد إنه لما كان موته حقيقة واقعة مهما طال عمره أو قصر، ناسبه التعبير عن ذللك : بقد " التحقيقية الداخلة على الماضي التي تقيد مع التحقيق الاهتمام والدوام • وقوله " في خط من الأرض " كناية عن القبر •

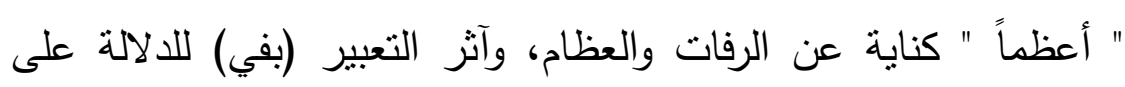
تمكنه من الأرض فهو في باطنها ـ وآثز التعبير بلفظة " خط" للتحقير وضآلة واتئ الحفرة التي يدفن بها ولا أدل على ذلك من مجيئه بها نكرة ؛ مبالغة في شدة فئرة الحقارة .

وأكد ذلك بقوله " من الأرض " لتحقير شأن الميث أي لا يتجاوز جزء قليل من الأرض،فمن هنا للتبعيض أب بعض من الأرض ويقابله من الكنايات العامية

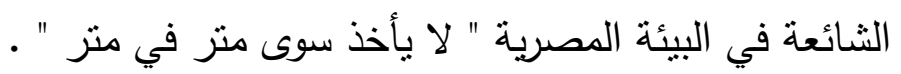
وآثز التعبير بقوله " بساق" دون غيره من " أخذ - حمل .... " للالالة

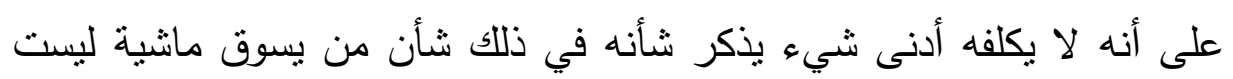
ملكاً له ويدفعها أمامه فهي تمشى وحدها لا دخل له له بهاء لهانه سوى الاقتياد؛ فكانت

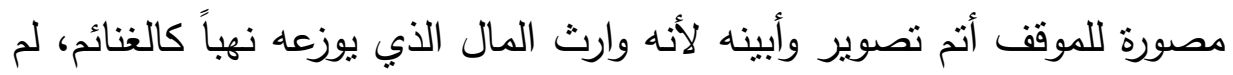

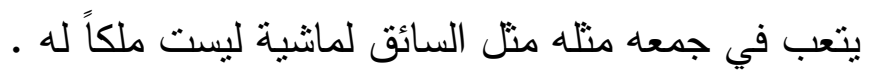

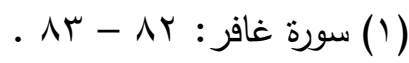

$$
\begin{aligned}
& \text { (r) الزمخشرى - الكثاف الجزء الأول ( سبق ذكره ) ص (ror) }
\end{aligned}
$$




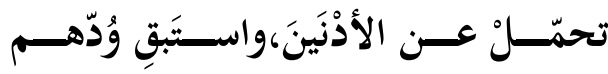

ولــن تســتطيعَ الحِلْـــمَ حتــى تَحلَّمـــا

المعنى : يقول الطائي مستتصحاً صاحبه المتخيل قائلاً إياه :

تحمل عن أقاربك مالا يستطيعون حمله، واستبق ودهم،فإنك لن تستطيع

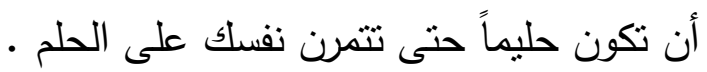
الوصل في البيت :

ربط الثـاعر بين الجملتين " تَحمَّلْ عن الأدَنَينَ" وجملة " واستبق ودهم "

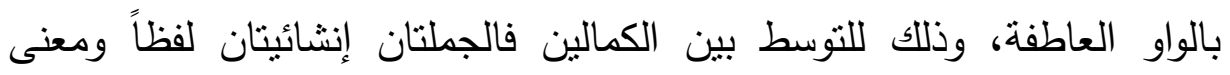
والمسند إليه فيهما واحد، وهو الضمير المقدر العائد على المخاطب والمسند

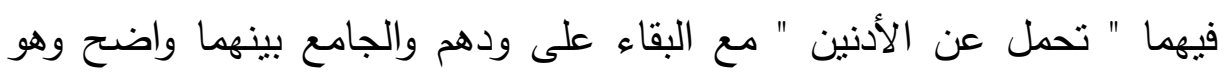

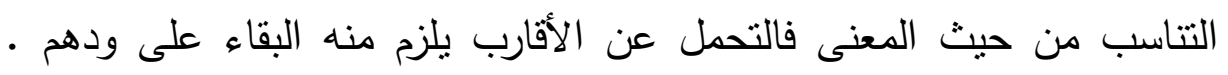
والأفعال " تحمل - استبق " بينهما تتاسب في الأمرية الذي خرج للنصح والإششاد، وسر بلاغة التوسط بين الكمالين هنا هو كما يقول الزمخشرى في الكثاف والإنتاف،

( يكون الوصل عن طريق التوسط بين الكمالين من أجل إحكام ترتيب

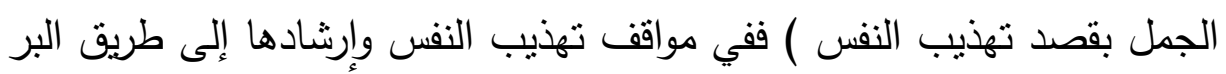
وأخذ الوسائل التي تبعد بها عن مواطن الذم [بلمح الزمخشرى إلى أن الترتيب بين

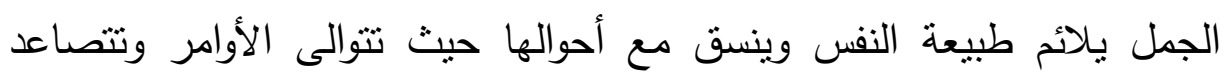

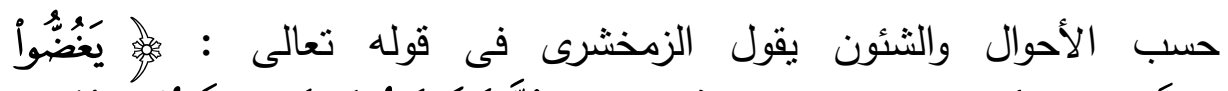

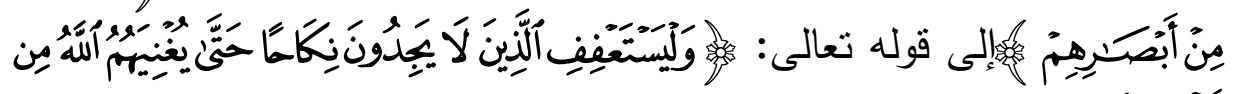
فَضْ ما أحسن ما رتب المولى سبحانه هذه الأوامر حيث أمر أولاً بما يَعْصٌِ

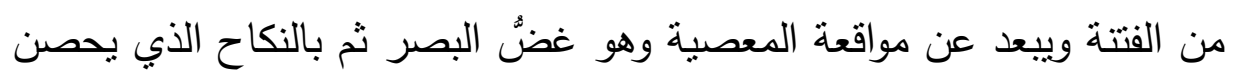




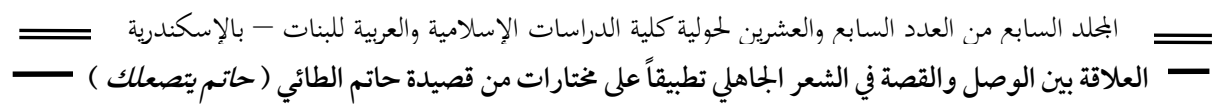

به الدين، ويقع به الاستغناء بالحلال عن الحرام ثم بالحمل على النفس بالسوء

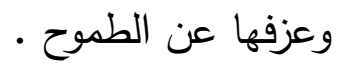

إلى الثهوة عند العجز عن النكاح إلى أن يرزق القدرة عليه ] (').

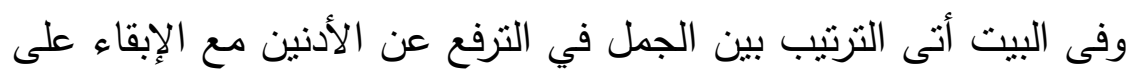
ودهم ولن تستطيع الحلم حتى تتعود .

.... هذا، ولئلا يتوهم السامع أنه أمر بالبعد عن الأدنين ومقاطعتهم أنى بالاحتراس في قوله " واستبق ودهم " أي عدم المقاطعة لهم ولما كان هذا لا يفي

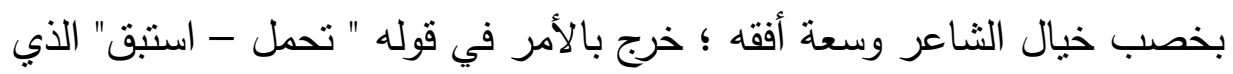

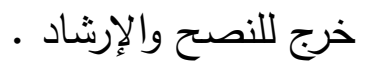
...هذا، وبين شطري البيت وصل؛ لان الجملة الأولى لها محل من

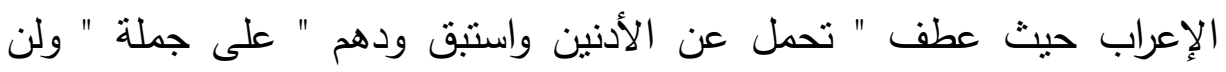
تستطيع الحلمَ حتى تحلما " .

والقيمة البلاغية لهذا الوصل: هي تقرير المعنى، فالجملة الثانية مقررة لما في الأولى من معنى يجب تنتيته في النفس •

وإذا تأملنا إيحاءات الألفاظ ودلالتها المختلفة لوجدنا صوغه الأفعال في "

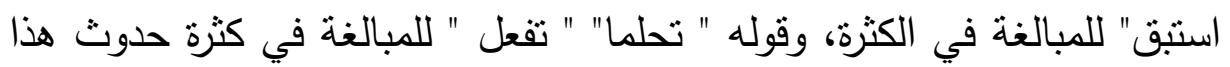

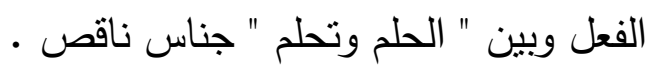

والطائي موفق في اختيار ألفاظه فكلها في مجال النصح والإششاد لما

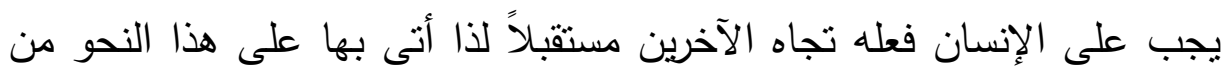

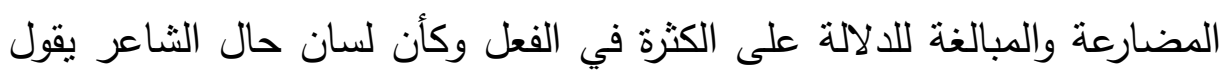

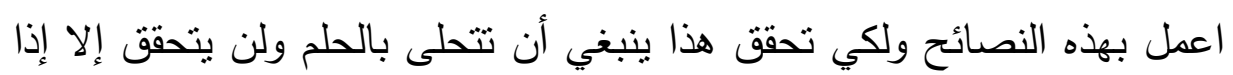

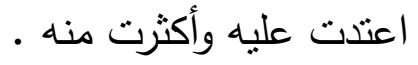

( (1) الزمخرى - الكثاف " سبق ذكره " الجزء الثالث - ص (70) . 


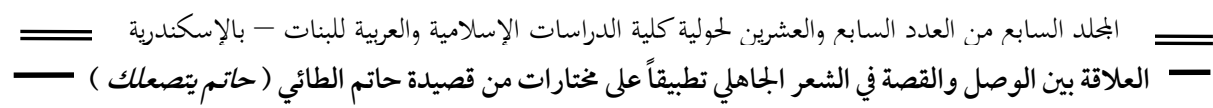

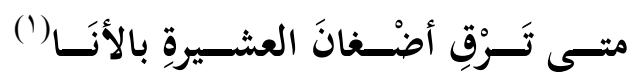

وكسفُّ الأذى يُحسـم لهم الداء مَحسـما(؟)

المعنى : يقول الطائي إذا ما عالجت أضغان العشيرة بالرفق وكف الأذى

فإنه يقضى على الداء تماماً .

لنبدأ بالوصل : ربط الثاعر بين قوله " متى ترق أضغان العثيرة بالأنا "

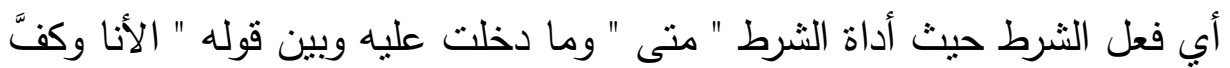
الأذى " من قبيل عطف المفردات بعضها على بعض " الأنا وكفَّ الأذى " وذلك فئ فئه لغرض بلاغي وهو بيان تعدد الصفات التي يجب على الموصوف الاتصاف بها

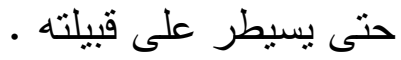

ولما كان هذا لا يفي بالمعنى المطلوب الذي حرص عليه نجده ناسبه التعبير عن ذلك بالاستعارة في قوله (ترق) من الرقية للثفاء حيث شبه "لابه " المعالجة المعنوية " وهى إيجاد الحلول " بالمعالجة الحسية " وهى الرقية للشفاء بجامع الوصول لحل في كل ثم بعد الحذف والتتاسي والإدعاء، استعار المشبه به وهنه للمشبه على سبيل التبعية في الفعل " ترق" وسر جمالها أنها أكدت المعنى

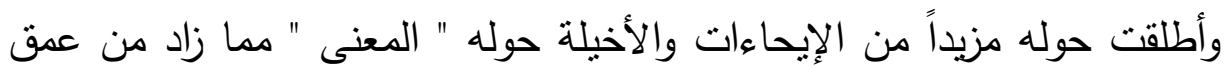
المعنى واتساعه .

ونمضى نحو ظل آخر من ظلال لوحته البلاغية فنجد الاستعارة المكنية

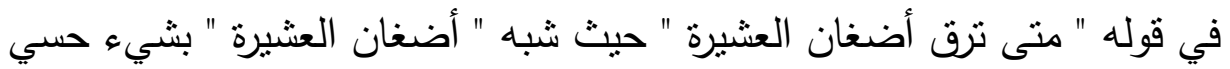

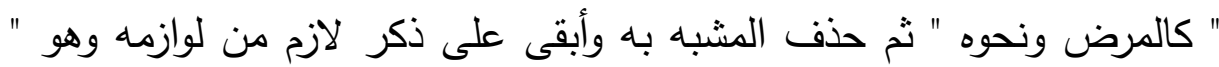
ترق" ثم تتاسى التشبيه وادعى أن المشبه فرد من أفراد المشبه به وداخل في ديه

(1) الأنا : نرخيم الأناة أي الصبر والحلم ، ومنه قولهم : من الأناة رجل أني ذو أناة ـ ينظر

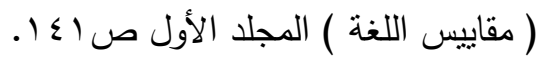

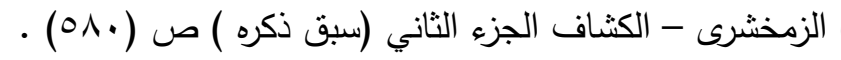

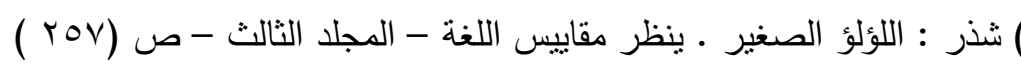




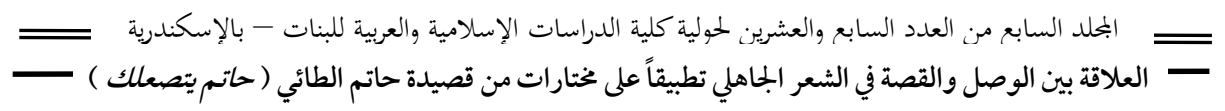

جنسه، ثم استعارة المشبه به " المرض" المحذوف والمكنى عنه بذكر لازمه للمشبه على سبيل المكنية .

. . هذا، واجتماع هذه الاستعارات في النص الواحد، يجلب للمعنى أبعاداً

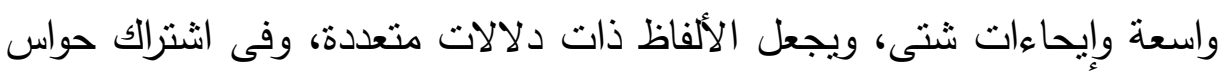
الإنسان وقوى الإدراك من نظر وسمع وعقل في التقاط المعنى وما يوحى به، وما ولاهـ يرمز إليه ، ويدل عليه ما يعطى للنفس فرصة للاندماج بالكامل، والوحدة ولدئ

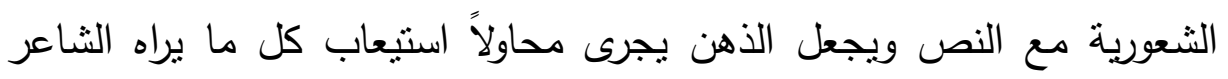
ويرمز به أو إليه وهو غرض دقيق لاجتماع هذه الاستعارات في نص واحد ومن

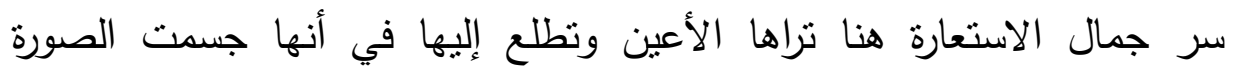

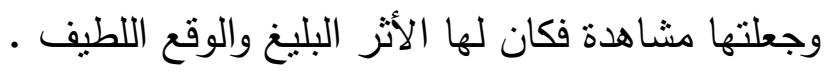

" فالأضغان " صارت دائماً مرضاً محسوساً يمكن أن يعالج، فالاستعارة

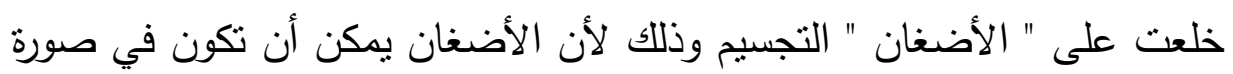
داء محسوس؛ لأن صاحبها يأكل في نفسه . يقول الإمام عبد القاهر الجرجاني :

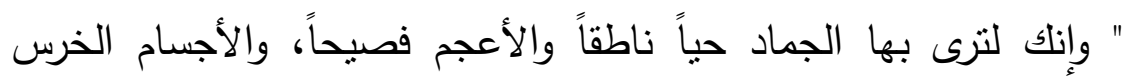
مبينة، والمعاني اللطيفة التي هي من خبايا العقل كأنها قد جسمت حتى رأتها

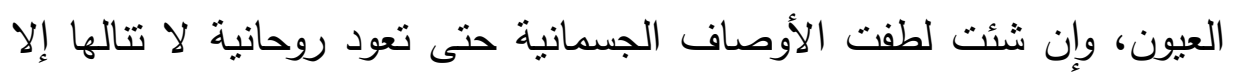

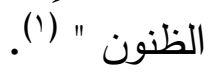

والطائي بارع في صوغ لوحاته بأكثر من ظل بلاغي بحيث يجعل القارئ

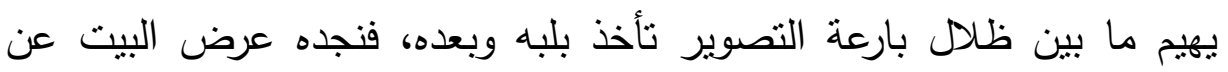
طريق أسلوب الثرط، [ و " أسلوب الثرط " من أطرف الأساليب التي قد يلجأ

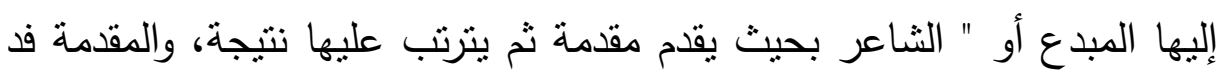

(1) فتحي بيومي حمودة : ( أسلوب الثرط بين النحوبين والبلاغيين ) - ط دار البيان العربي

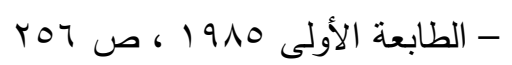




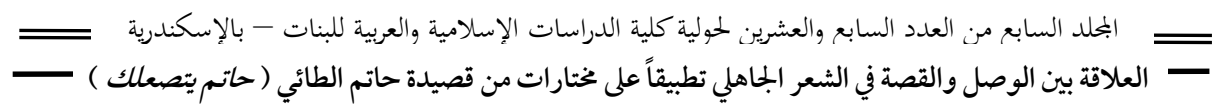

تكون من المتعارف عليه، أو من صنع خياله وكذا النتيجة، قد تكون منوقعة أو من تصوراته وهنا مكمن السحر ومستقر الجمال ] (').

وفى رأيي : إن ما قد أعانه على ذلك هو خصوصية معاني الثرط " إنْ - - منان

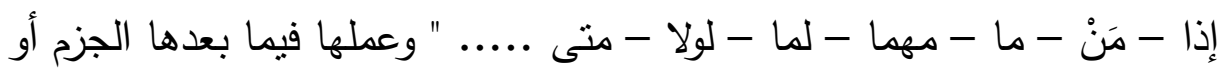
عدمه، ثم الترابط الذي يثند طرفي الصورة بوثاق متنين و " منى " هنا أداة الربط

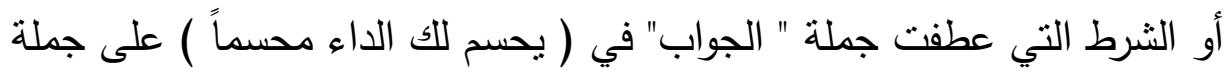
الشرط البلاغية " متى ترق أضغان العشيرة بالأنا وكف الأذى " لغرض بلاغي : وهو " التوسط بين الكمالين " فالجملتان خبريتان لفظاً ومعنى والجامع بينهما " اتحاد المسند إليه فيهما " وهو " الضمير العائد على المخاطب " والمسند فيهما وهو " معالجة الأضغان وكف الأذى وبينهما تتاسب في المعنى فالحديث عن " معالجة الأضغان وكف الأذى بستلزم الرفق واللين لذلك . ـ وبهما بحسم الداء

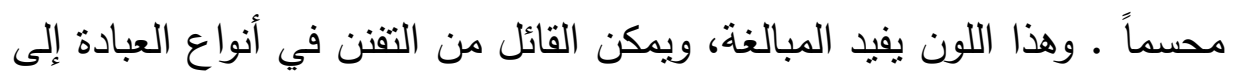
جانب تمكين المتكلم من وصف نفسه أو مخاطبه بما يريد دون حرج • هذا وصوغ البيت على هذا النحو من المجاز مع الثرط لون بارع يسمى " التجوز في الشرط " الذي من شأنه أن يكسب الصورة شدة المبالغة ويطلق مزيداً من الإيحاءات والأخيلة حول المعنى مما زاد من عمقه واتساعه (r).

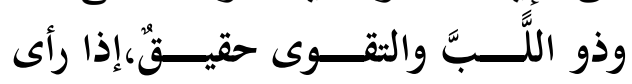

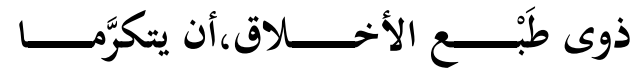

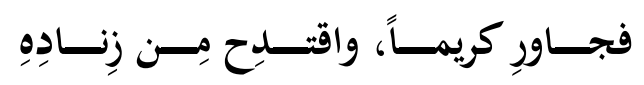

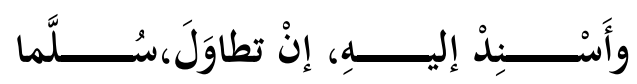

الحديث موصول مع النصح والإرشاد للصاحب المتخيل .

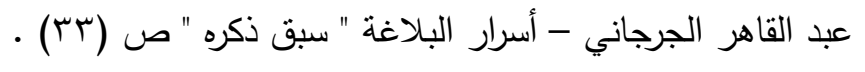

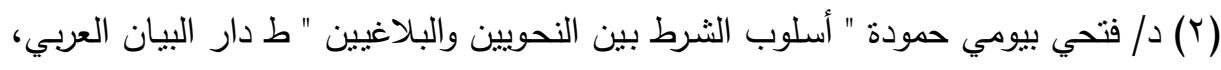

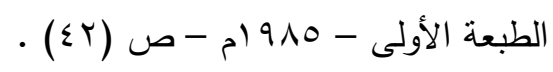




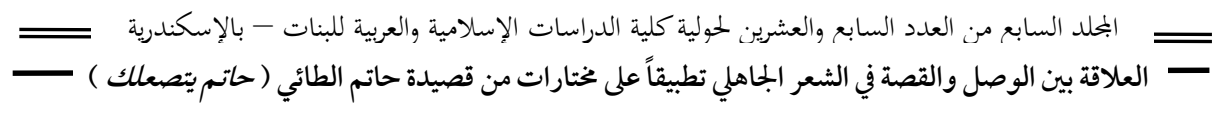

المعنى : يقول وصاحب العقل والتقوى حري به إذا رأى صاحب الأخلاق المشينة أن يتكرما أبي يكثر من الكرم عن طريق مجاورة الكريم والاستفادة من

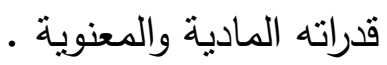

الوصل في البيت : أتى به الطائي عن طريث عطف المفردات بعضها على بعضٍ في قوله [ ذو اللب والتقوى ] ل

والسر وراء مجئ هذا العطف كما ذكره الزمخشرى في الكثاف يقول : " والوصل بين الصفات المتعددة يأتي لأغراض بلاغية

( أ ) لبيان تعدد الصفات للموصوف . ل

( ب) لكمال الصفات في الموصوف .

( ج ) لبلوغ أحد الموصولين شهرة الآخر في الصفة .

ووصل الطائي هنا لغرض: " لكمال الصفات في الموصوف "

وقد تقع الواو بين الصفات للإثارة إلى أن الموصوف بلغ الكمال في كل صفة منها .

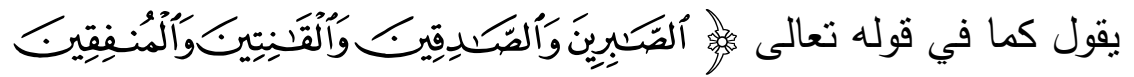

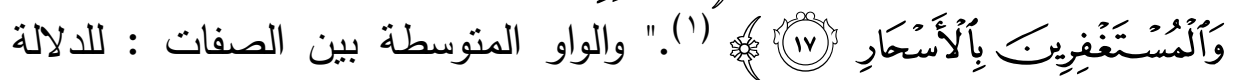
على كمالهم في كل واحدة منها " (r). فالواو المتوسطة بين الصفات " ذو اللب والتقوى " لبيان أن صاحب هذه الصفات جدير بها وحري به إذا رأى صاحب الأخلاق السيئة أن يكون أكثر كرماً

$$
\text { فجـــاورِ كريمــاً، واقتــدح مِسـن زِنــادِهِ }
$$

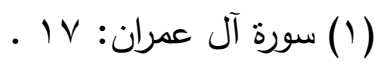

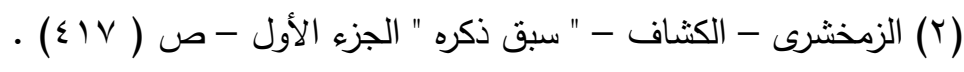


=

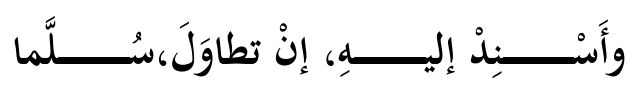

الحديث موصول بالفاء مع ذو اللب والتقوى الذي ينبغي عليه أن يكثر

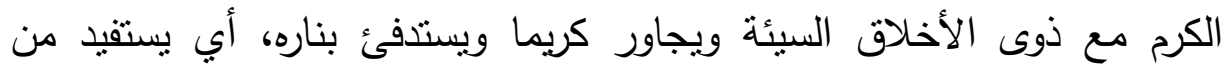

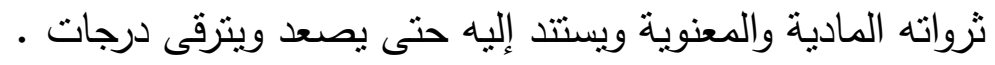

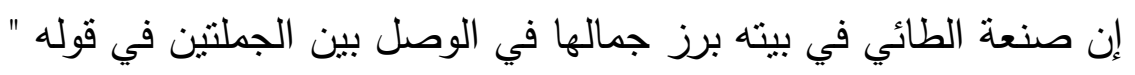

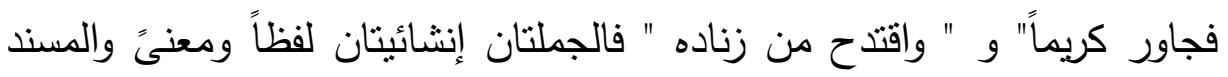

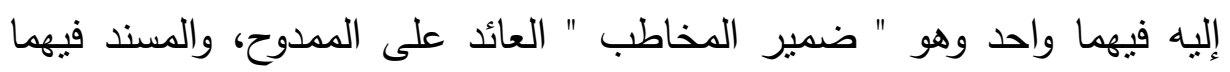

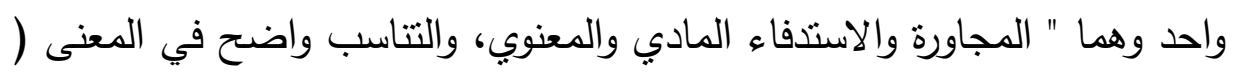
المعنوي ) فالمجاورة لكريم تقتضى الاستدفاء المادي والمعنوي والاتكاء عليه

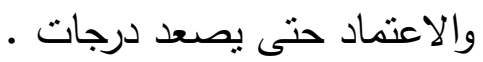

وسر بلاغة الوصل هنا " تقديم المهم أو الأقوى أثراً ثم الأقل يقول

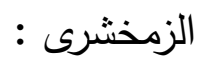

وذلك كما في قوله تعالى : " لنحي به بلدة ميتاً ونسقيه ممّا خلقنا أنعاماً

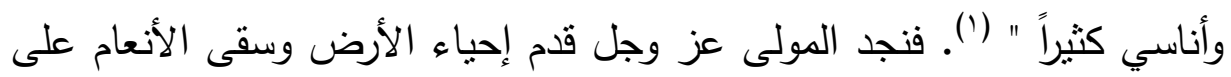

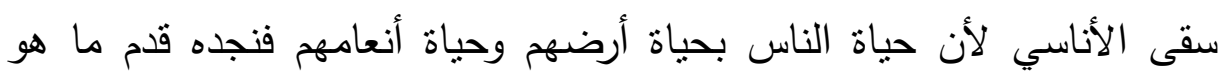
سبب في حياتهم وتعيشهم على سقيهم " (؟). وهنا نجد الطائي قدم المجاورة للكريم لأنها تأنى أولاً ثم الاقتناح من زناده

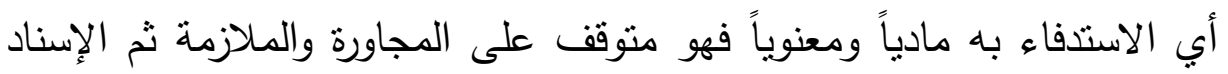

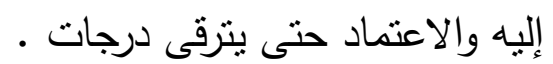

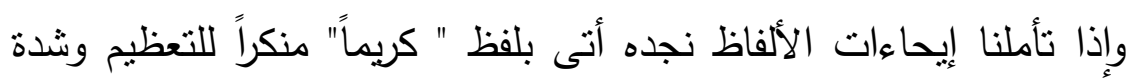

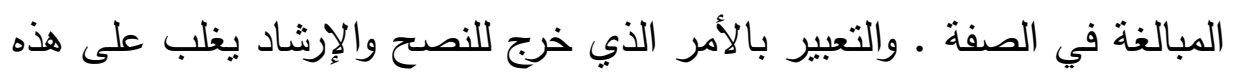

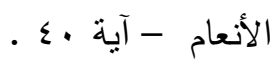

$$
\begin{aligned}
& \text { (Y) الزخشرى - الكثاف ( سبق ذكره ) الجزء الرابع ص (بـ) . }
\end{aligned}
$$




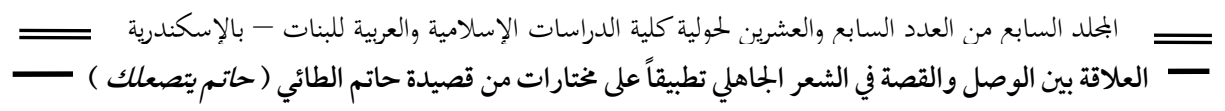

المقطوعة في خطابه المخيل مع صاحبه المتخيل، وهذا كعادة الجاهلين حيث

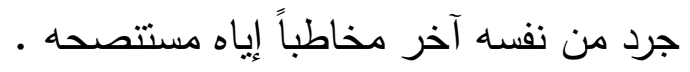
فضلاً عن التعبير بالمجاز في قوله " واقتدح من زناده " حيث شبه الكريم " بالزند" وهو الحجر الذي يضرب ببعضه حتى يشتعل ويستخدم في الاستدفاء . .... الخ على سبيل المكنية وهرية

والمقصود بالاقتداح هو الاستفادة من القدرات المادية والمعنوية للكريم

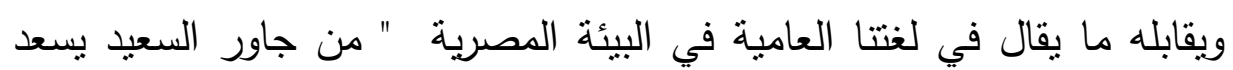
" الخ.....

وعطف الثرط الثاني من البيت على أوله لأن الأولى لها محل من

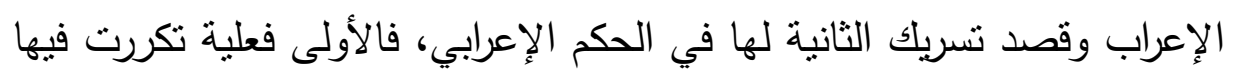

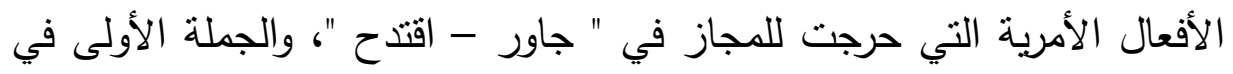
محل نصب حال والثانية عطفت عليها، ثم عطف الثطر الثاني على الأول للتشريك في الحكم الإعرابي وقوله " إن تطاول " في تأويل مصدر أبي الصعود

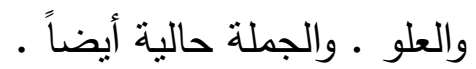

.... هذا، والطائي موفق في اختيار ألفاظه فأتت مصورة للبيت الذي قصده أتم تصوير وأبينه .

والبيت كناية رائعة عن حسن الاختيار، لأن من جاور صديق أو صادقة

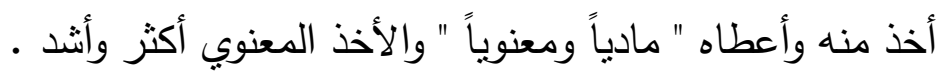
...هذا، وبعد ما تحدث عن نفسه في وصفه إياها بقوله ذو اللب والتقوى

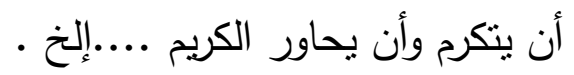
وكما تحدث الطائي عن ذوى الأخلاق الحسنة ويعنى به نفسه وهو ذاك

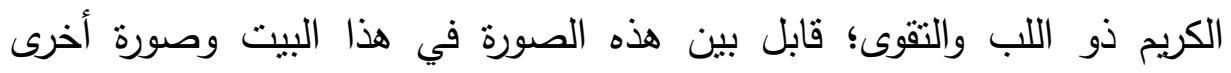
يتحدث فيها عن ذوى الأخلاق القبيحة الذي يجب الإعراض عنه وهذا لا يضر،

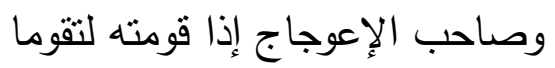




\section{: يقول

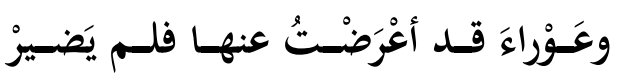

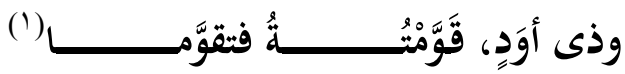

وصل الطائي بين شطري بيته بالواو العاطفة للتوسط بين الكمالين، فالجملتان خبريتان لفظاً ومعنى ، والمسند إلبه فيهما واحد " الضمير العائد على بلى ليه الممدوح " " الثاعر نفسه " والمسند بينهما هو الإعراض عن العور وتقوبم ذوى الأود والتتاسب بينهما واضح وهو شبه التضاد، فالتقوبم كا شبه الضد للعور لأن العور أي المعيب " القبيح " .

والسر البلاغي للوصل هنا هو : " إحكام ترثيب الجمل بقصد تهذيب النفس

كما ذكره الزمخثرى فى الكثاف :

" إحكام ترتيب الجمل بقصد تهذيب النفس كما في قوله تعالى:

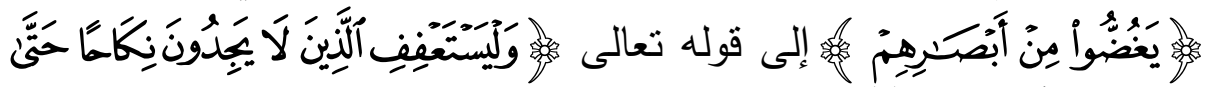

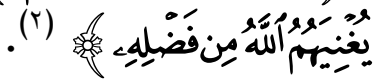

( يقول ما أحسن ما رتب هذه الأوامر حيث أمر أولاً بما بعصم عن الفتتة

وبيعد عن مواقعة المعصية وهو غضُّ البصر ، ثم بالنكاح الذي بحصن به الدين، ويقع به الاستغناء بالحلال عن الحرام ثم بالحمل على النفس بالسوء وعزفها عن الطموح إلى الثهوة عند العجز عن النكاح إلى أن يرزق القدرة عليه " (r). وهنا في البيت وصل الطائي حيث بدأ بالإعراض عن العور، وهو القبح من الأخلاق والأفعال، وإن هذا الإعراض لا يضر ، ثم ثقوبم صاحب الاعوجاج

(1) ذوي أود : أي صاحب عوج • ينظر ( مقاييس اللغة ) المجلد الأول ص ( ع أ ) . (Y) سورة النور - آية (•r - سب)، الزمخشرى - الكثاف ( سبق ذكره ) الجزء الثالث ص

الزمخشرى - الكثاف ( سبق ذكره ) الجزء الثالث ص (10) . 


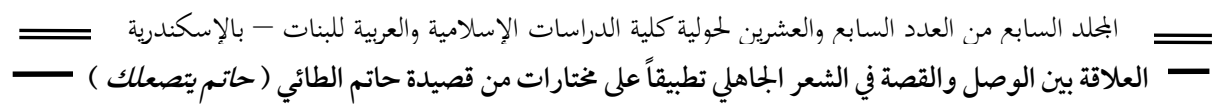

(أي في الوسائل والطرق ) التي يسلكها؛ فيستجيب للتقويم فالإعراض عن العور ، لأن الخلاق والطباع لا تتغير ؛ لذا قال لا يضر أما قال في ( الأود- قومته -

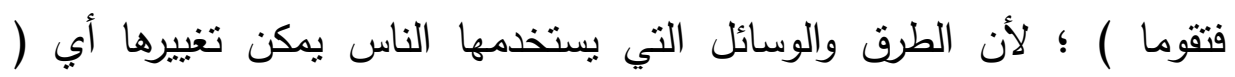
اعوجاج المنهج سهل تغييره ) الطن

وإذا ما تأملنا إيحاءات الألفاظ ودلالتها لوجدنا ما يلي :

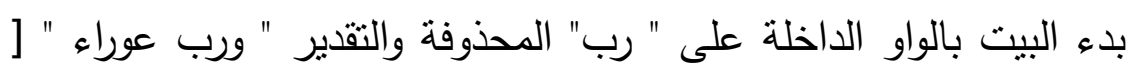

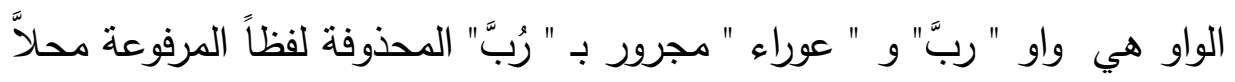
على أنها مبتدأ " ولا تدخل إلا على منكرٍ، ولا تتعلق إلا بمؤخر" (').

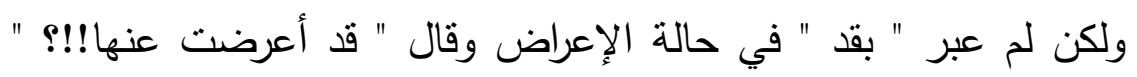

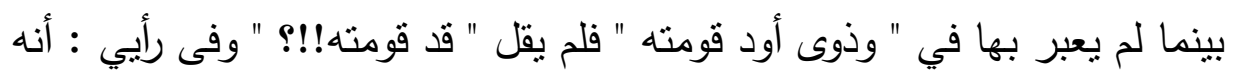
أنى بقد مع الإعراض عن العور؛ لأن العيوب والقبح الذي يتعلق بالأخلاق

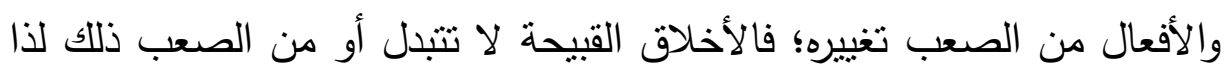

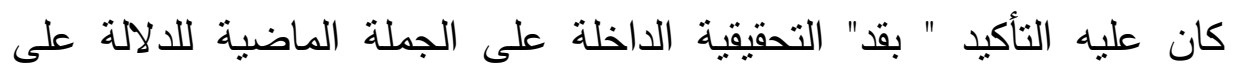
التمكن والدوام والاستمرار في "الإعراض" لأنه لم يضر بينما لما كان الاعوجاج

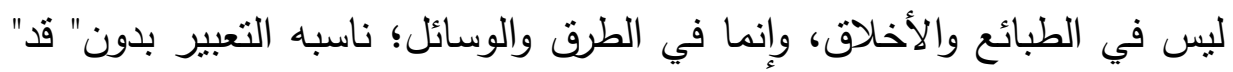

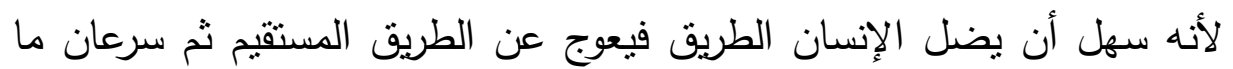
يعود إليه إذا ما قُوم •

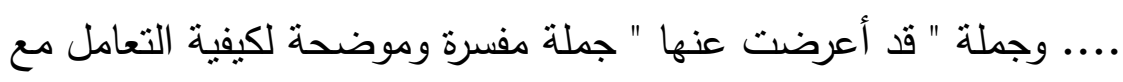

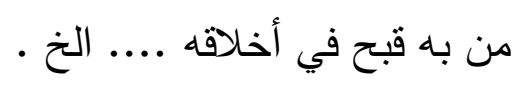

وفى إضافة الإغراض إلى نفسه في " أعَرَضثُ" للتأكيد على شدة المبالغة في البعد الواقع منه لا من غيره .

وقوله " فلم يَضِرْ" الفاء عاطفة أفادت الترتيب والتعقيب؛ ربطت الجملة

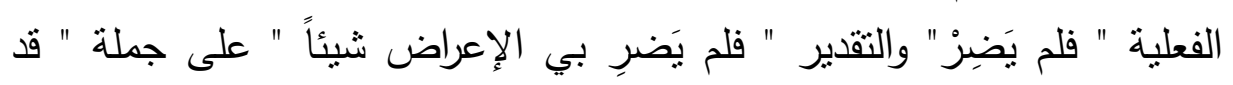

$$
\text { (1) ابن هشام النصارى - مغنى اللبيب عن كتب الأعاريب - ص [ (1)] . }
$$




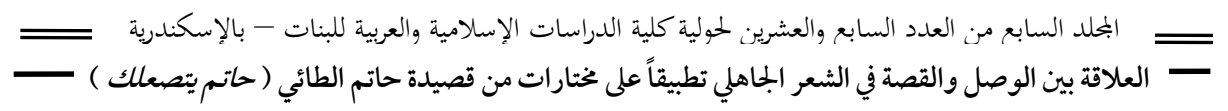

أعرضت عنها " لما بينهما من التوسط بين الكمالين " فالجملتان خبريتان لفظا

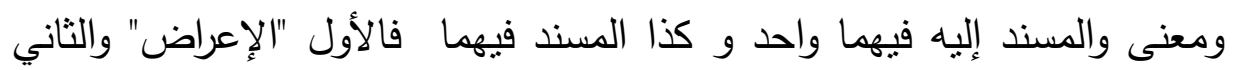
"عدم الضرر"، والتتاسب بينهما واضح في المعنى فالإعراض عن الإنسان القبيح الأخلاق لا يضر بالمعرض شيئاً وبين الإعراض عن القبح وعدم الضرر مراعاة

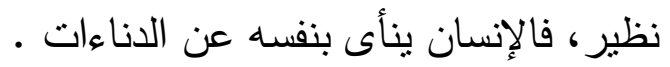

والسر البلاغي لمجيئه على هذا النحو : هو شدة التأكيد على القبح لكي لا

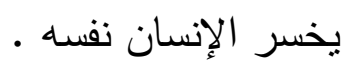

هذا.. ، ويعد التضاد من الأدوات الفنية البارزة التي أسهمت بدور كبير في تشكيل صور الطائي الثعرية، وإبراز موقفه الفكري وذللك؛ عن طريق المطابقة

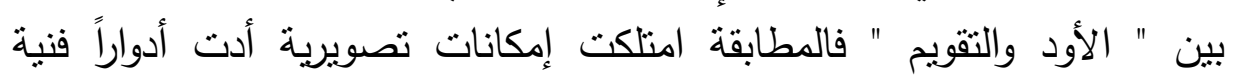

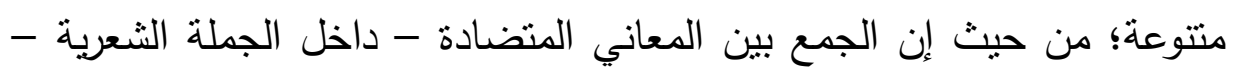

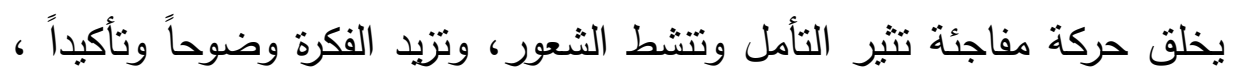

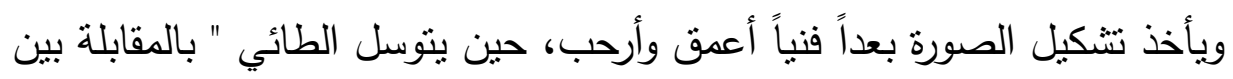
شطري البيت " ليوظف موقفه. والمقابلة - كما بذكر ابن رشيق :

" مواجهة اللفظ بما يستحقه الحكم وأصلها ترتيب الكلام على ما يجب فيعطى أول الكلام ما يليق به أولاً وآخره بما يليق به آخراً، ويأني الموافق بما يوافقه، وفى المخالف بما يخالفه " ('). كما نجد دقة الاختيار للمفردات وخصوصية الاستخدام فنجده لما أراد إظهار التخصيص له دون غيره ـ قال : قومته " بإضافة التقويم إلى نفسه حيث التئ

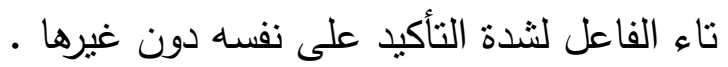

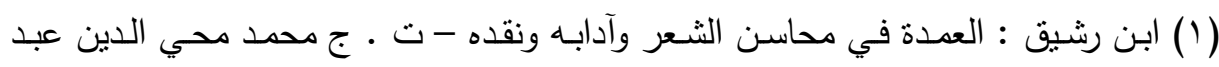

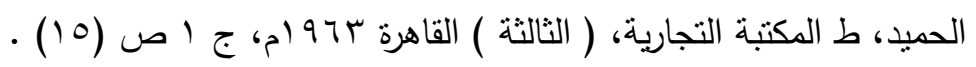




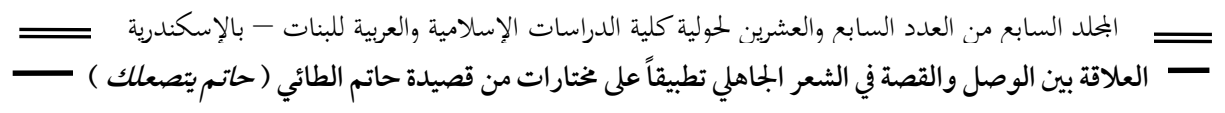

وفى إسناد التقويم للإعوجاج دونما فاصل بينهما لبيان سرعة الانجاز

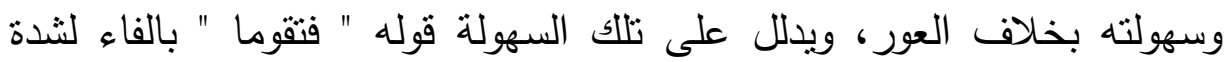
الثرعة والتتابع في الفعل وسرعة ظهور الأثر الناتج عن التقويم مباشرة . وبين " قومته - فتقوما " جناس اشتقاق

هذا ...، ولما كان الإعراض عنه منوقعاً منه الأذى؛ ناسبه التعبير عن ذلك " بلم " التي هي حرف نفى وجزم وقلب؛ للتأكيد على عدم الإيذاء؛ لأنه منوقع من صاحب الأخلاق السيئة .

والحديث موصول عن العوراء • وقرنها هنا بالكريم • يقول :

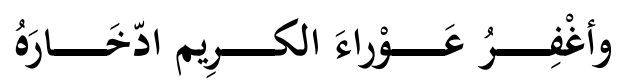

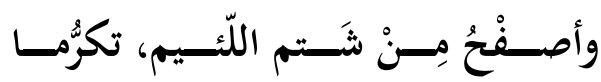

يتحدث عن العوراء المستثناة من الإعراض، وهى عوراء الكريم •

يقول إذا رأيت في الكريم مذمة فأغفرها له فإن صفاته أكبر من مذماته وأما اللئيم فأحرص عن شتمه أو التعرض له بسوء كرماً منى ونرفعاً . فنجده عرض البيت في معرض المقابلة بين طرفيه لإظهار الفرق بين

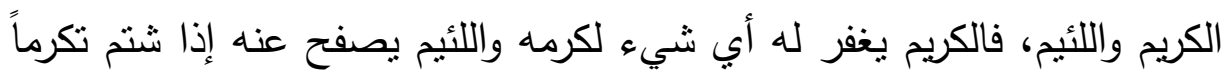
منك أي ترفع بنفسك أن نتأى بها في تتبع عوراء وسقطات الآخربن . وعرض البيت على هذا النحو يمكن الصورة في الذهن ويحدث حركة ونشاطاً تثير الوعي وتحرك الانتباه .

وللطائي في ربطه بيته صنعة هائلة في الوصل بالواو العاطفة؛ وذلك

لغرض بلاغي وهو التوسط بين الكمالين • فالجملتان إنشائيتان لفظاً ومعنى والمسند إليه فيهما واحد وهو المخاطب

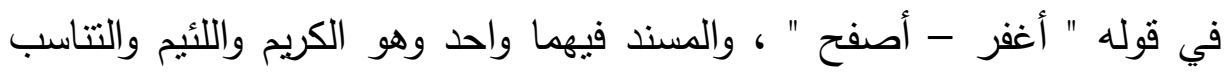

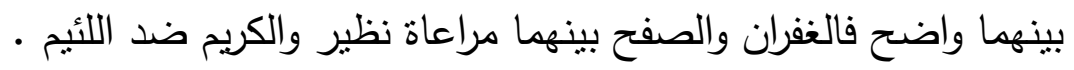




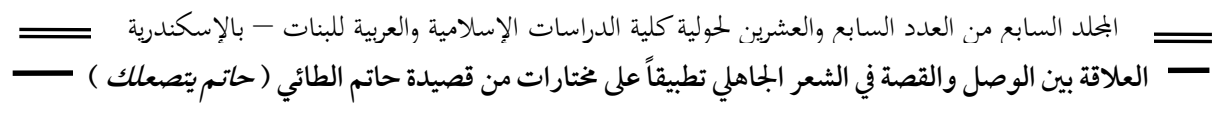

والسر البلاغي للتوسط بين الكمالين هنا : هو إحكام ترتيب الجمل بقصد تهذيب النفس وذكره الزمخشري ووضحته سابقاً .

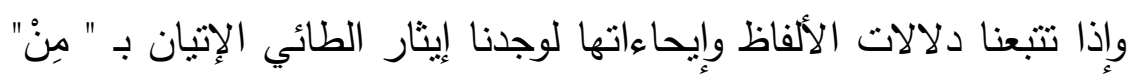

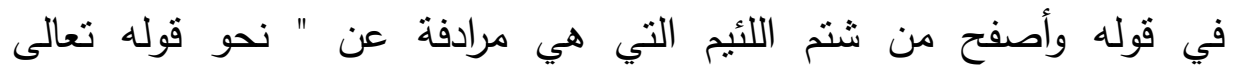

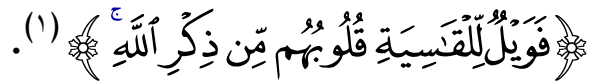
فيكون معناها في البيت " وأصفح عن شتم اللئيم تكرما " فالصفح " يكون عن " أما الأخذ " فيكون من " وخرج الطائي بالأمر في " أغفر لـأصفح " للنصح والإرشاد .

وعرض البيت على هذا النحو من المقابلة بين طرفيه تتضمن في ثناياه الطباق ـ فنجده بين " الكريم - اللئيم " وبين " الادخار - الكرم " وبين " الغفران

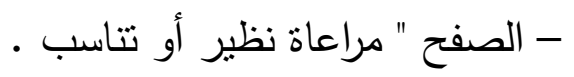

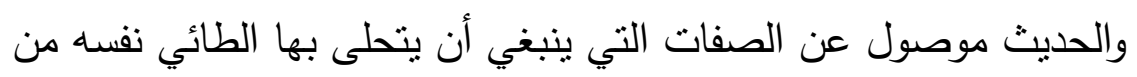
حيث " إعراضه عن العوراء - استثنائه عوراء الكريم - والصفح عن شتم اللئيم

\section{يقول : \\ ولا أخْــذُلُ المــؤلى، وإن كــان خــاذِلاً}

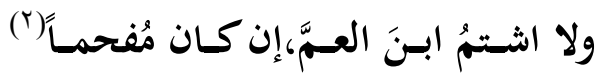

في هذه المقطوعة من الأبيات ظهرت ذاتية الطائي أو التأكيد على ذاتيته فنجد ( ولا أخذل) والتقدير " أنا " .

(1) ابـن هثــام النصـارى - مغنـى اللييـب عـن كتـب الأعاريـب [بــق ذكـره ] جا ص [OTI).

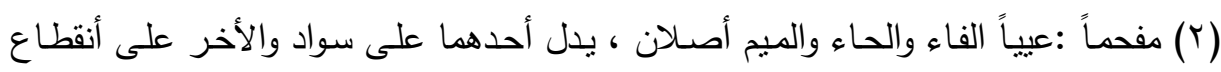

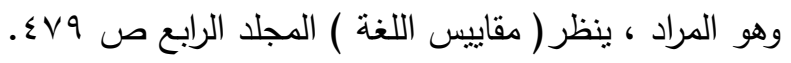




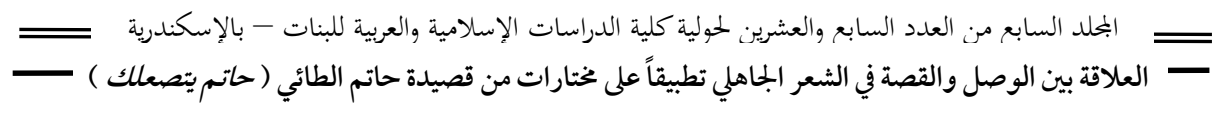

وقوله " ولا أثتنم " والتقدير " أنا " وبينهما نتاسب في المضارعة والبيت

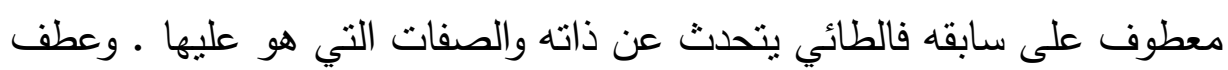

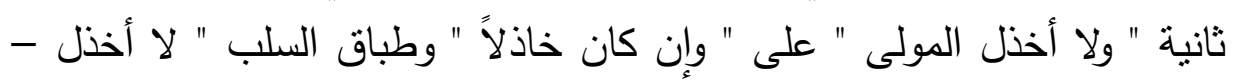

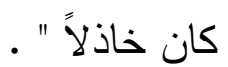

والقيمة البلاغية له : ذكرها العلامة الإمام الزمخشري في الكثاف نكاد

$$
\begin{aligned}
& \text { تتحصر في ما يلي : } \\
& \text { يقول الزمخشري : }
\end{aligned}
$$

" الوصل بين الصفات المتعددة لبيان تعدد الصفات للموصوف ـ ـ كما في

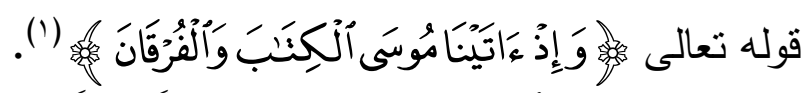

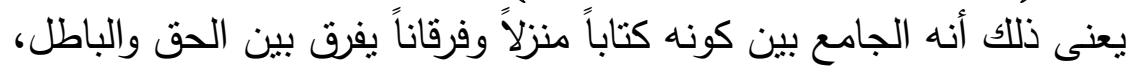
يعنى : التوراة ، وكقوللك : رأيت الغيث والليث، تريد الرجل الجامع بين الجود

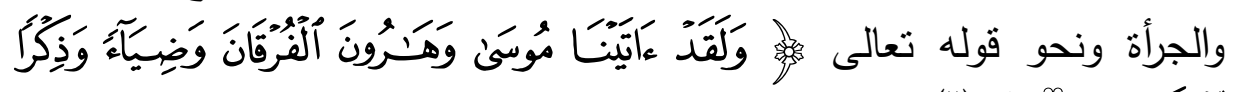

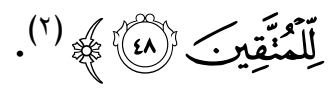

يعنى الكتاب الجامع بين كونه فرقانا وضياءً وذكراً " ().

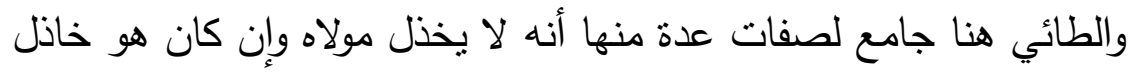
وأنه لا يشتم ابن العم وإن كان مفحماً .

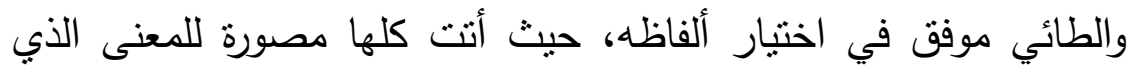

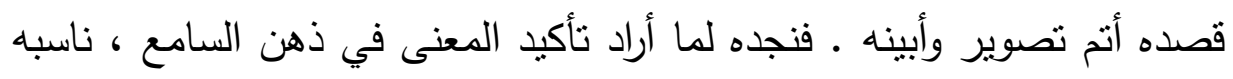

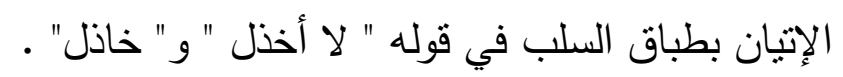
الوصل في البيت :

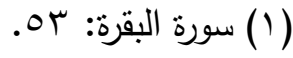

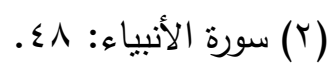

$$
\begin{aligned}
& \text { (r) الزمخشرى - الكثاف - الجزء الأول - ص (YN) (Y) . }
\end{aligned}
$$


=

عطف جملة " وإن كان خاذلاً " على جملة " ولا أخذل المولى " بالواو

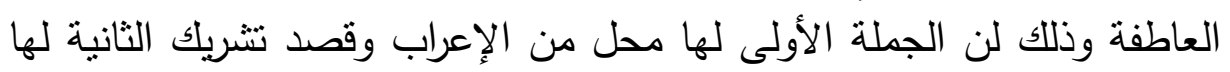

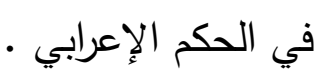

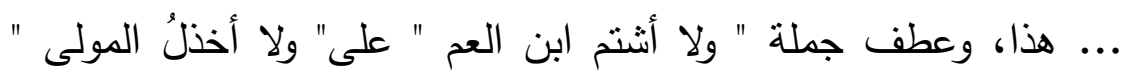

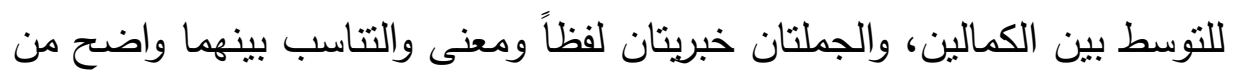

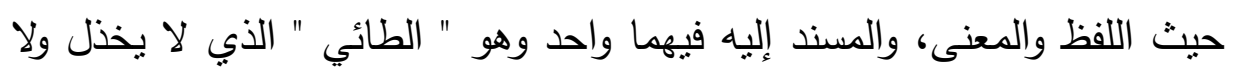

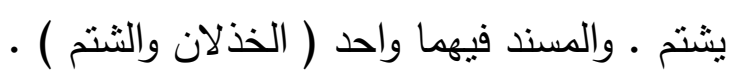

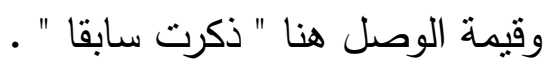
فالسؤال هنا :

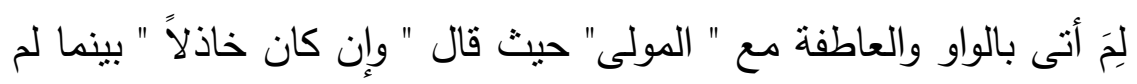

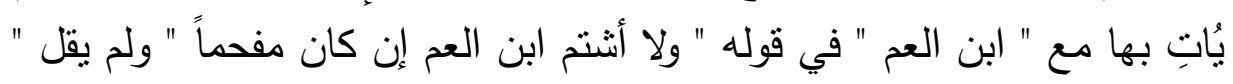
وإن كان مفحماً " .

وفى رأيي : لعل السبب في ذللك هو أنه فصل بالواو مع المولى لأنه

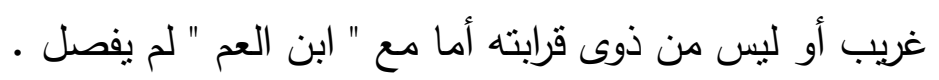

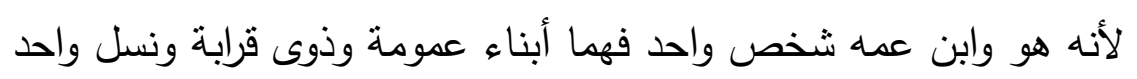

والتتاسب واضح بين شطري البيت حيث قوله " ولا أخذلّ المولى " وقوله " ولا أثنتُم ابنَ العم " .

ومن حيث التتاسب اللفظي حيث أنى بالواو والعاطفة في كل يليها " لا"

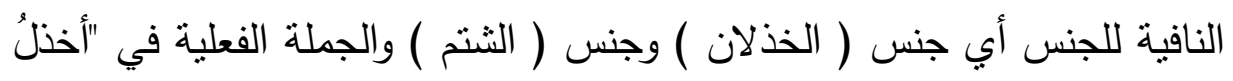

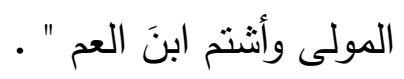
وكذا في نهاية الثطر الأول ونهاية الثرط الثاني ـ " وإن كان خاذلاً - إن إن

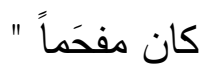
من حيث خبرية الجملتان والمسند إليه فيهما واحد وهو " الضمير " العائد

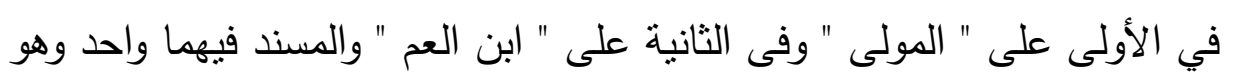




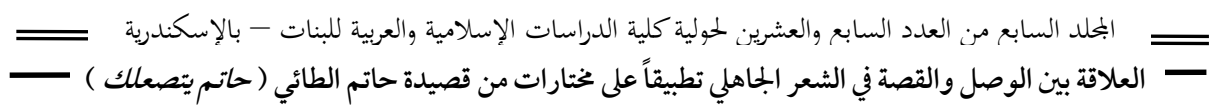

الصفة المعيبة في الأولى " الخذلان" وفى الثانية " الإفحام " فالثاعر موفق في

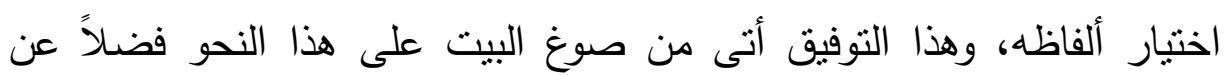

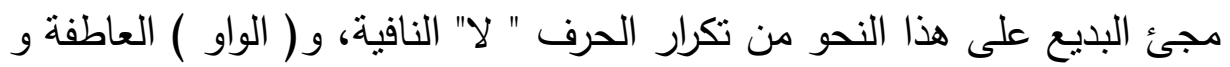

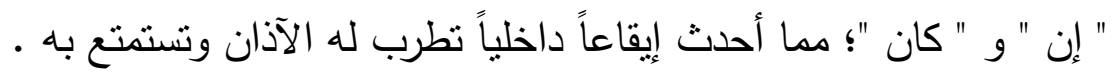

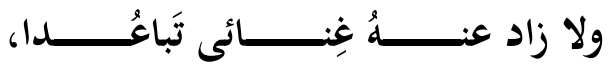

وإن كـان ذا نقـصِ مـن المـالِ، مُصـرماِ(')

الحديث موصول مع صفات الطائي الكثيرة فنجد صنعة الطائي في بيته موفورة أجاد فيها عن طريق الوصل حيث ربط بين شطري البيث بالواو العاطفة؛

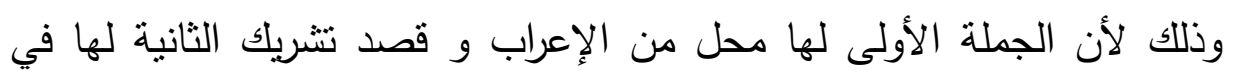

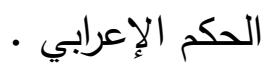

والوصل هنا لبيان تعدد الصفات للموصوف يعنى الثخص الجامع بين كونه " لا يخذل المولى ولا يشتم ابن العم - ولا يتعالى ويبعد إن كان غنياً " .

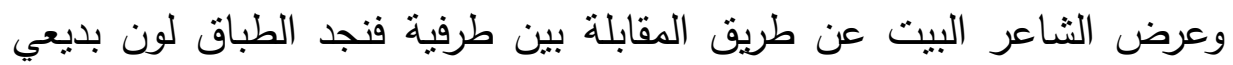

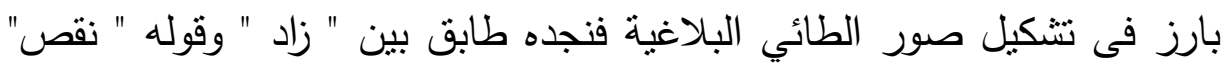

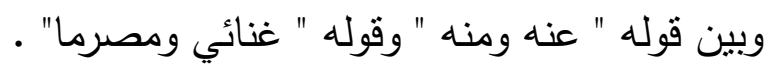

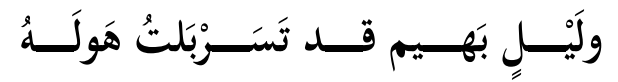

إذا الليـلُ بـالنَّكسِ الضـعيف تجهَمـا(؟)

المعنى : الحديث موصول مع صفات الطائي الرابعة، يقول :

وليل شديد السواد والظلمة ـ لا تخيفني ظلمته بل على العكس لبست هوله وخوفه بينما الإنسان الجبان الضعيف يتجهم الليل في وجهه ويخيفه .

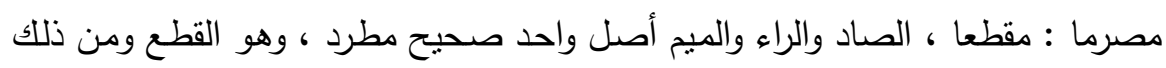

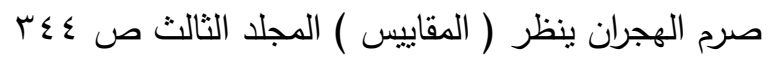

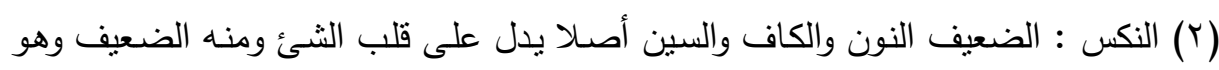

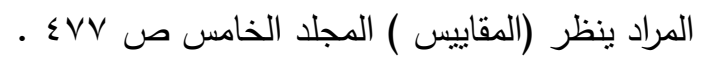




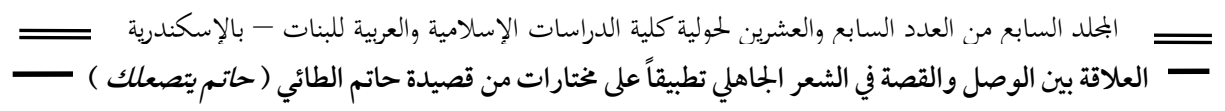

الوصل في البيت : ربط الثاعر بالواو العاطفة في بدايته وذلك؛ لعطف صفات الطائي التي لا مثيل أو حدود لها ـ لون

ولنتأمل تكنيته عن شجاعته الفائقة قائلاً بأنه جعل سواد الليل وعتمته ثياباً وتسربل هو هذه الثياب " ثياب الخوف والوحثة " والمجاز في قوله " قد تسربلت هو له " حيث الاستعارة المكنية حيث شبه هول الليل ووحشته بالثياب التي تلبس وتغطى سائر الجسد ثم حذف المشبه به " الثياب " وكنى عنها بذكر لازم من هن النه

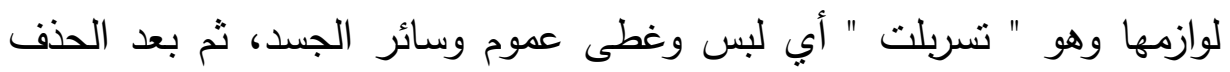
والتتاسي والادعاء استعار المشبه به المحذوف والمكنى عنه بذكر لازم من لوازمه وهيه

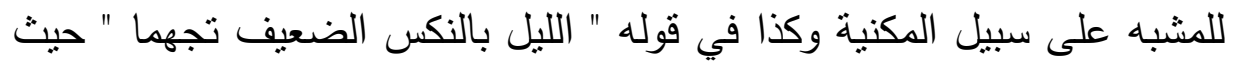
شبه الليل " بالإنسان " ثم حذف الإنسان وكنى عنه بذكر لازم من لوازمه وهو " تجهم " أي عبس في وجهه .... على سبيل المكنية .

وقيمة الاستعارة في الصورة الأولى أنها " جسدت هول الليل وخوفه " في

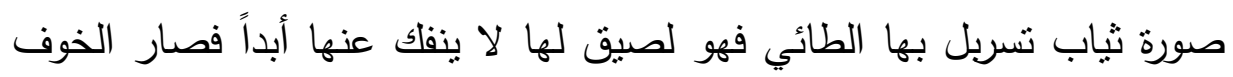

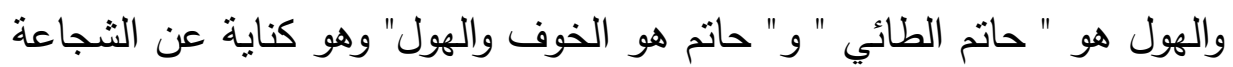
المفرطة على غير مثال سابق هول هوب

وقيمتها في الصورة الثانية : " الليل بالنكس الضعيف تجهما " [التتخيص] من حيث بث الحياة في الليل وجعله يذهب ويجئ ويعبس في وجه الجبان الخائف، ومما لا شك فيه أن تلك الاستعارات خلعت على اللوحة البلاغية

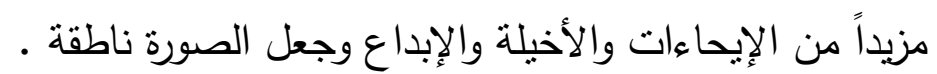

ولنتأمل إيحاءات الألفاظ ودلالتها، فنجد " قد " التحقيقية الداخلة على " تسربلت " الماضي للالالة على الثبوت والدوام وكأن شجاعته هذه ليست

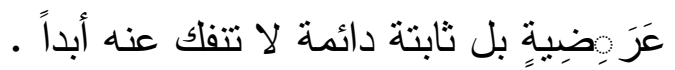


=

والتعبيرب " إذا " ( الطرفية، حيث خرجت إذا عن الثرطية لمعنى الظرف

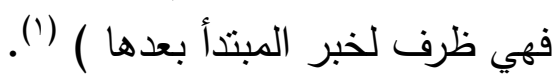

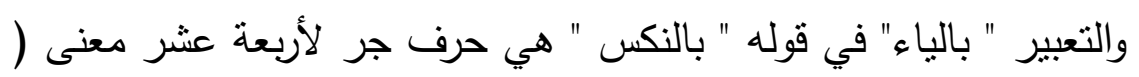

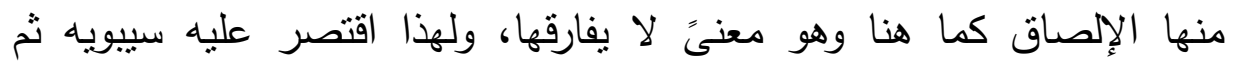

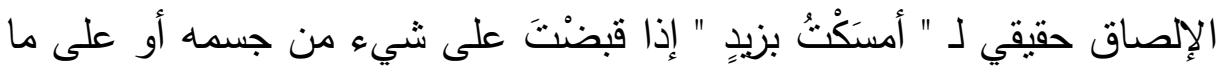

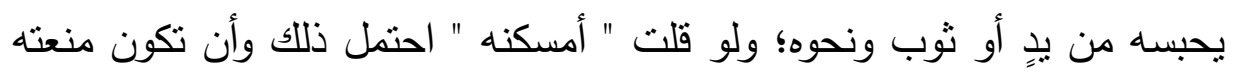

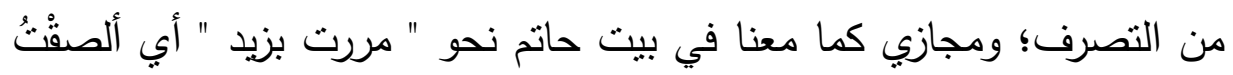

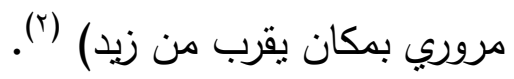

والمحازيّ هو المراد هنا وعليه يكون المعنى " إذا الليل ألصق أي لازم

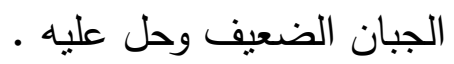

الحديث موصول عن "الصعلكة المحمودة " يقول الطائي : لن ينال

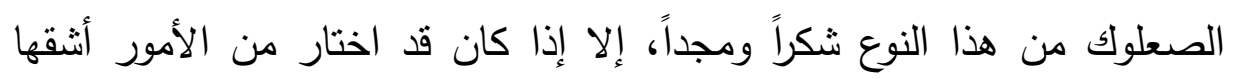

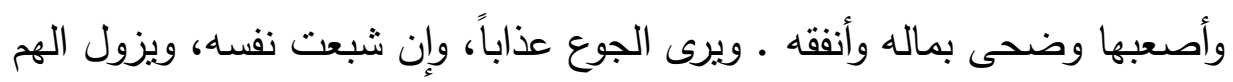
وينام مطئناً ولَنَ يكسِبَ الصَّعلوكُ حمـداً ولا غنسئ

إذا هَو لم يركبَ، من الأمرِ، مُعظَمَا يسرى الخَمـصَ تعـذيباً، وإنْ يلـقَ نَسبعةُ

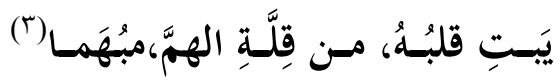

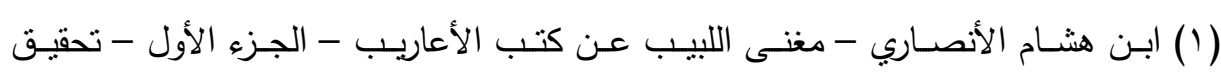

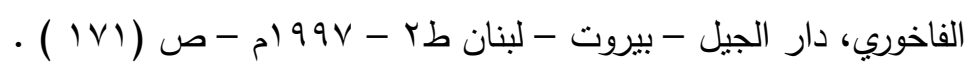

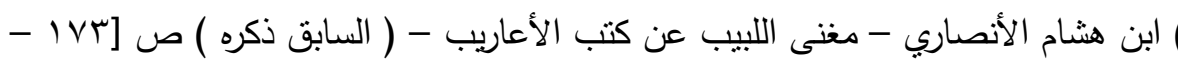

[ [ IVY

(r) الخمص : الجوع الخاء والميم والصاد أصلا واحد يدل على الضمر والتطامن ينظر

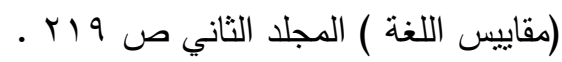




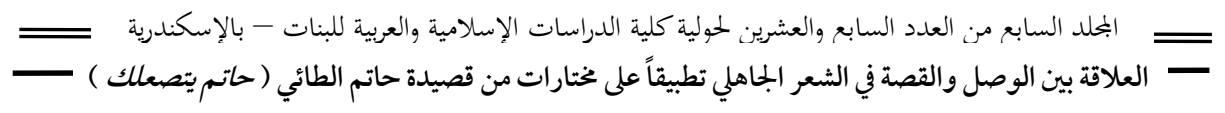

البيت معطوف على سابقه، وبدأ الثاعر نظمه الثعري بالجملة الخبرية

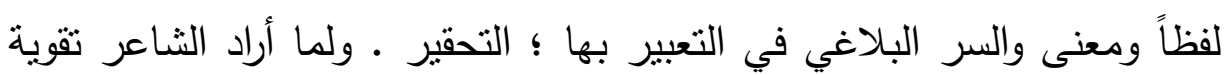

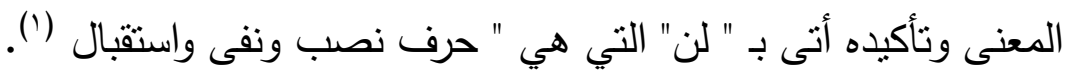
وآثز التعبير بقوله " يكسب " دون غيرها نحو " يفوز " مثناً وذلك للتأكيد

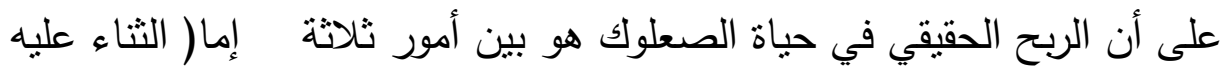

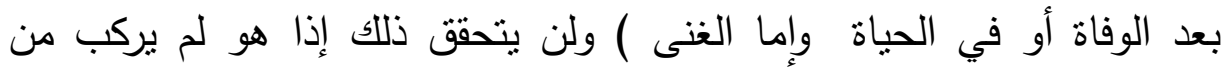

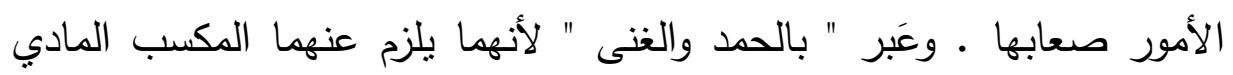

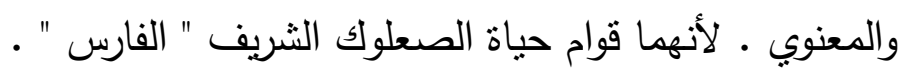

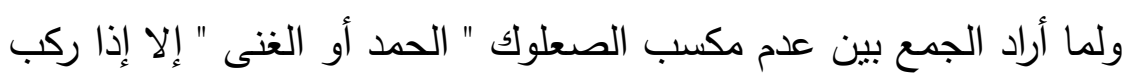

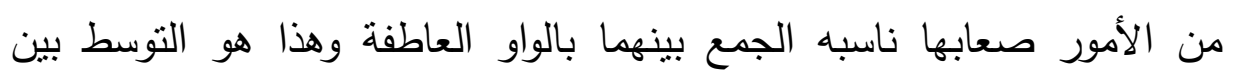

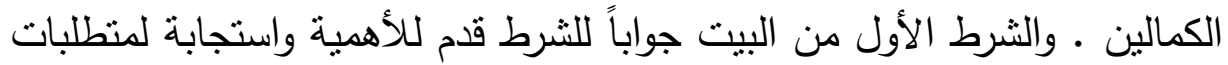

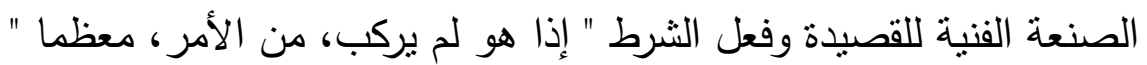
ولما أراد أن يفسر لنا نفيه للمكسب من الحمد والغنى مشروطاً بتحمل

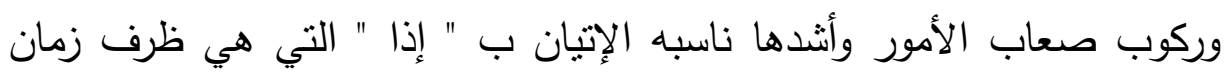

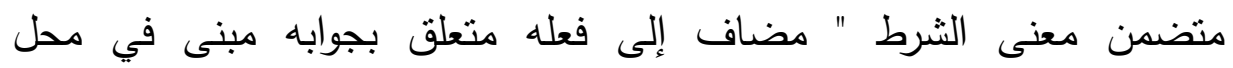
نصب"((). لتحديد الوقت والزمن الذي يتحقق فيه المكسب المادي أو المعنوي .

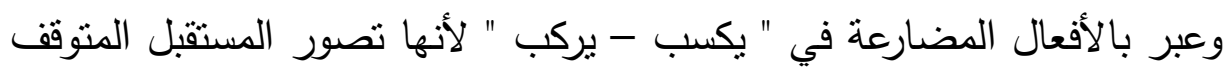

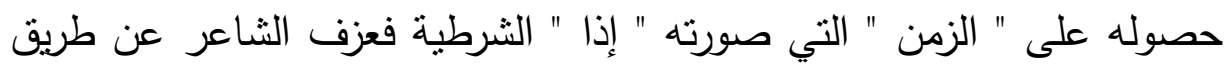

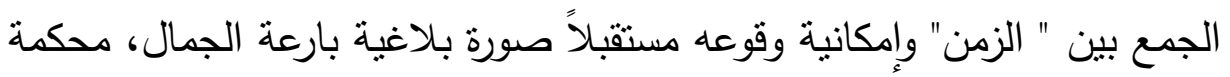

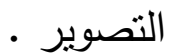

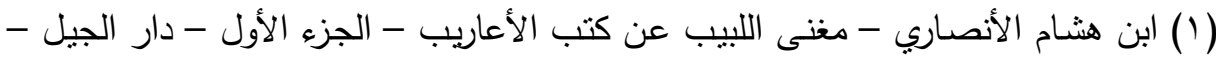

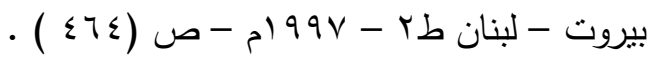

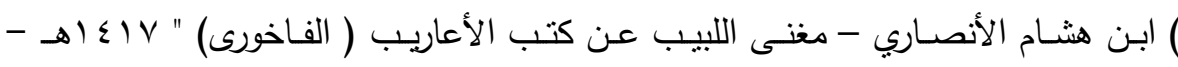

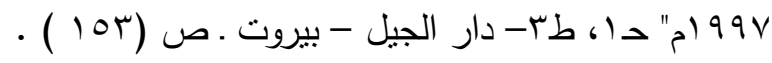




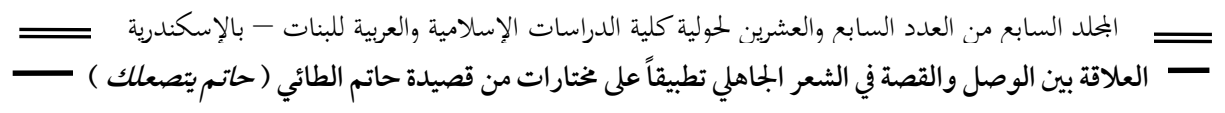

والحديث موصول عن الصعلوك الثربف البطل الذي يرى الخمص تعذيباً

وإن شبعت نفسه، ويزول الهم وينام مطمئناً .

$$
\text { يقول : تحمبه }
$$

يرى الخَمصَ تعذيباً، وإنْ يلقَ شَبعةً

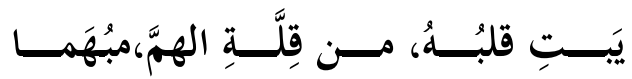

لما كانت الألفاظ دائماً في حالة قصور وعجز عن ملاحقة فيض المشاعر الإنسانية لذلك نجد الطائي يحاول اصطناع لغة أخرى تسمو إلى مستوى نفسه

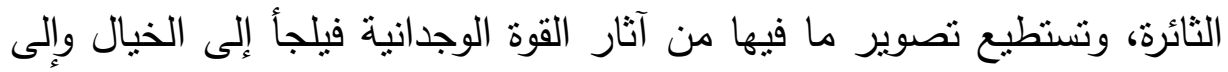
الصورة التي تزبط المعاني ببعضها وتتقها إلى درجة أرقى لتزداد جمالاً وعند ذلك ربط بين الجملتين بالواو العاطفة " يرى الخمص تعذيباً و إن بلق شبعة "

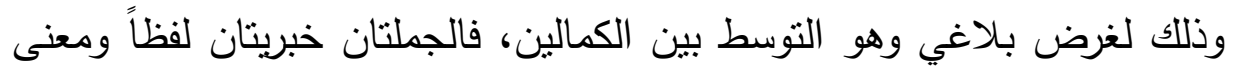

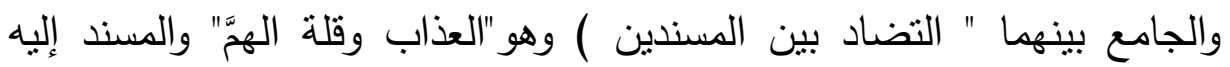

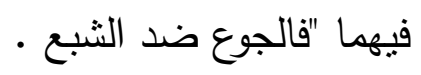
والثاعر موفق في اختيار ألفاظه حيث أتت مصورة للمعنى الذي قصده أدق تصوير حيث عبر بالأفعال المضارعة في " برى - تعذيباً - يلق - يبيت "

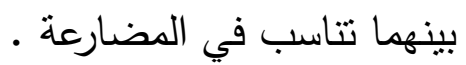
ويظل الطائي مسترسلاً في هذه الصورة ، المتقابلة الطرفين " الجوع والثبع " و" العذاب وقلة الهم " فقد أغرم الطائي بجمع الغريب عن طريق التقابل بين طرفيه؛ وذللك لكي تتمكن الصورة فضل تمكن وتجعل الذهن يعقد موازنة سريعة بينهما حتى يتضح الفرق وذلك؛ لكي يزيد الهوة بين طرفي الصورة الفنية حتى

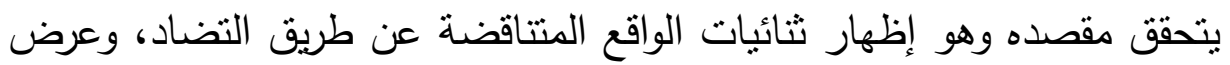
الصورة في معرض المقابلة بين طرفيها، والغرض هو : شدة المبالغة في التأكيد

$$
\text { على المعنى الذي أراده . }
$$

وفى رأيي : إن عرض الصورة على هذا النحو مما يجعل الهوة بين الطرفين واسعة، مما يثير الوعي ويلفت الانتباه ويثرى الصورة والجمع بين ثنائيات 


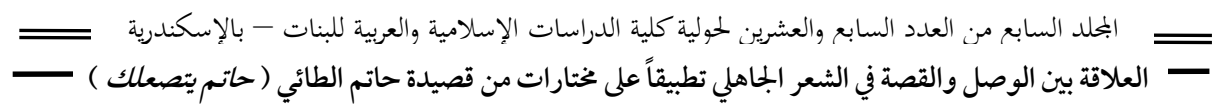

الواقع المتتاقضة يؤكد الفكرة، ويزيدها وضوحاً ولما كانت الحياة في نظر شاعرنا

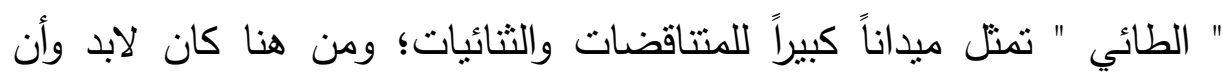
ينعكس في شعره - عن وعى أو غير وعى - صوراً من المتضادات. ومن هنا أصبحت الأداة ذات علاقة بموقف الثاعر في في وعين يذكر " الطائي " شيئًاً ثم لا يلبث أن يذكر آخر ضده ـ تستقر الصورة في الذهن أتم استقرار وأبينه ويتحقق التأكيد على مراده .

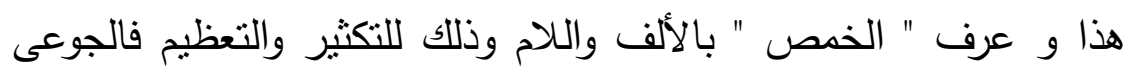

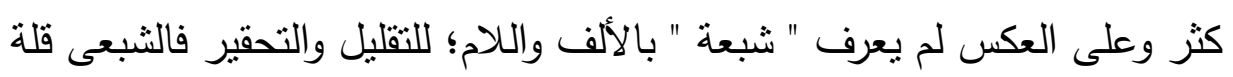
قليلة وجمل الصورة البلاغية بالإيجاز بالحذف الواقع بين شطر البيت الواحد في

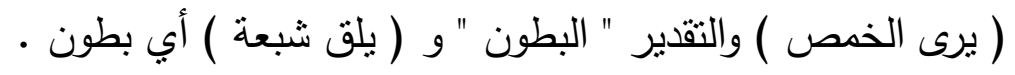

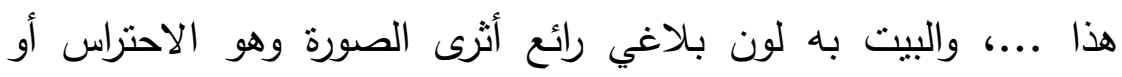

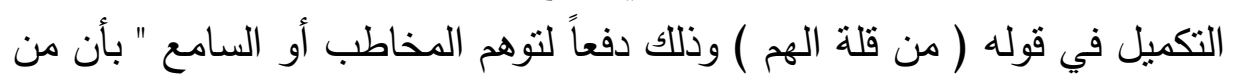

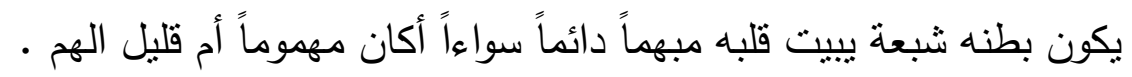

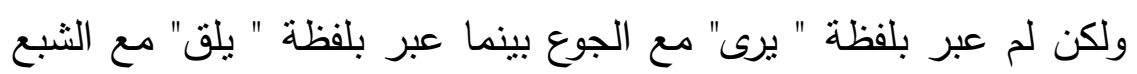

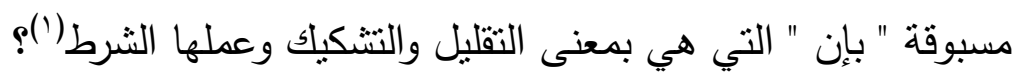

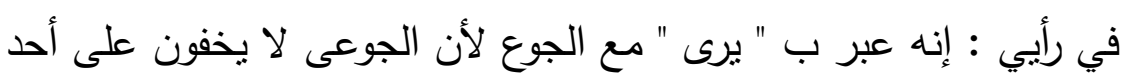

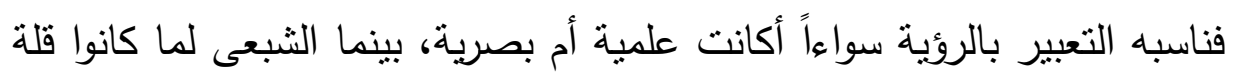

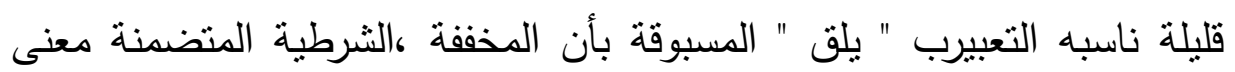

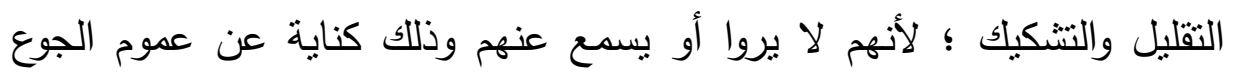

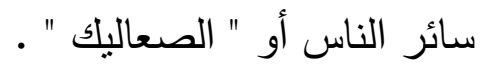

(1) ابن هشام الأنصاري - مغنى اللبيب عن كتب الأعاريب ( سبق ذكره ) - الجزء الأول- (1) ص (1) (1) (1) (1) 


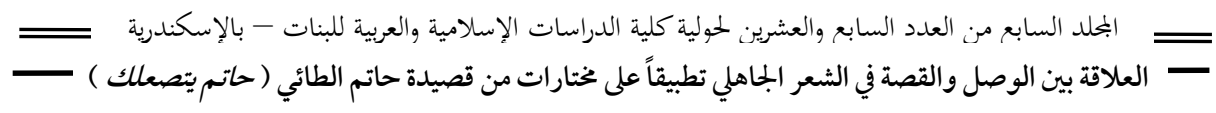

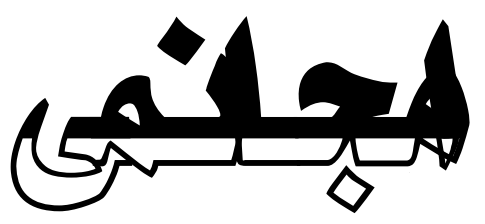

* la vaing

ألتم النتائج 
=

البحوث البلاغية بحوث إنسانية نختلف حولها وجهات النظر، وهذا

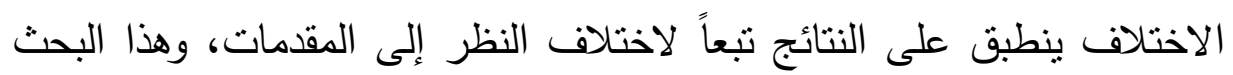

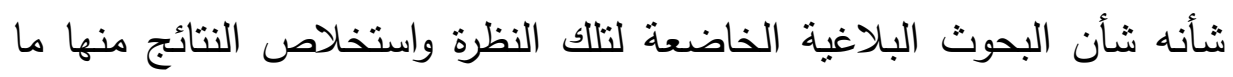
يقوم على وجهة نظر قابلة للأخذ والرد .

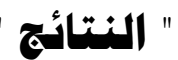

أولاً : غلبة " الطباق والمقابلة " على شعره، فهي تكاد تعطى معظم أبيات

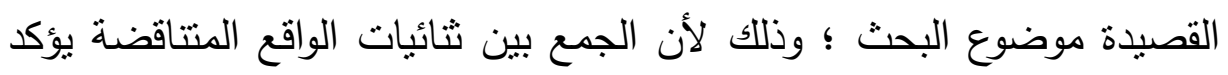

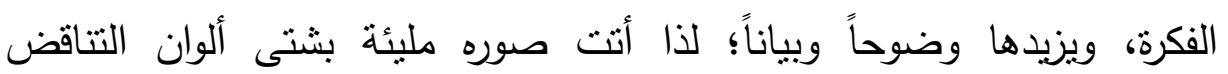

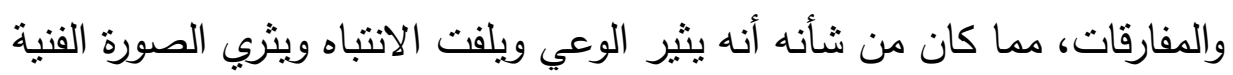

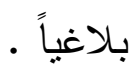

ثانياً : أسلوب الثرط في شعر حاتم الطائي موضوع خصب، بحاجة إلى . دراسة مستقلة .

ثالثاً : تتوع الأزمنة وتحولاتها داخل بنية الجملة ودلالتها بلاغياً وظهر ذلك

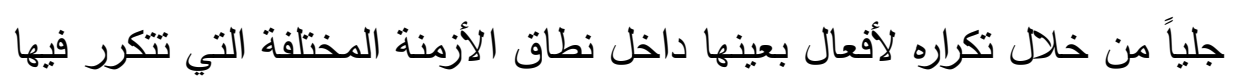

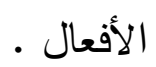

\section{لالاه التوصيات للآه}

أولاً : ينبغي نوجيه نظر الباحثين في ميدان البلاغة العربية إلى دراسة

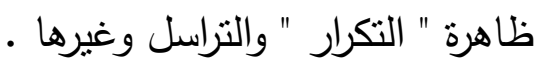
ثانياً: المفارقة في شعره ميداناً فسيحاً للمتتاقضات والثنائيات، لذا يمكن نسليط الضوء على هذه الجهة ودراسته دراسة بلاغية . 


\section{قائمة المصادر والمراجع}

\section{*بعد القرآن الكريم}

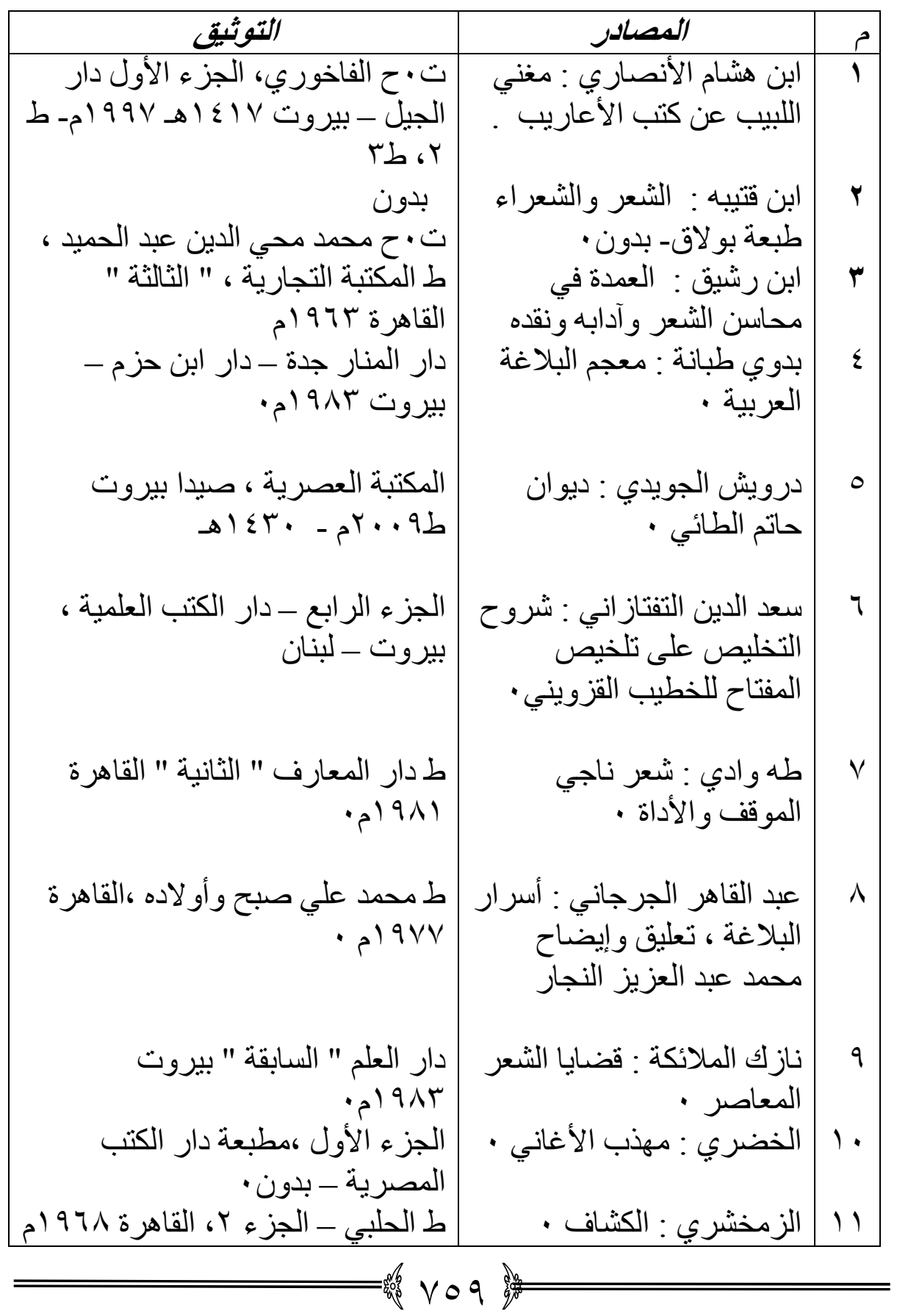




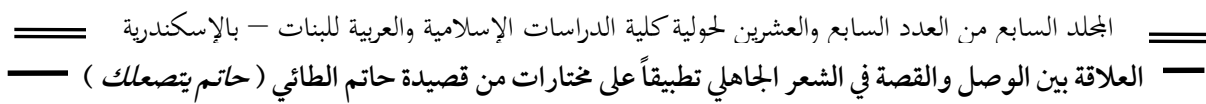

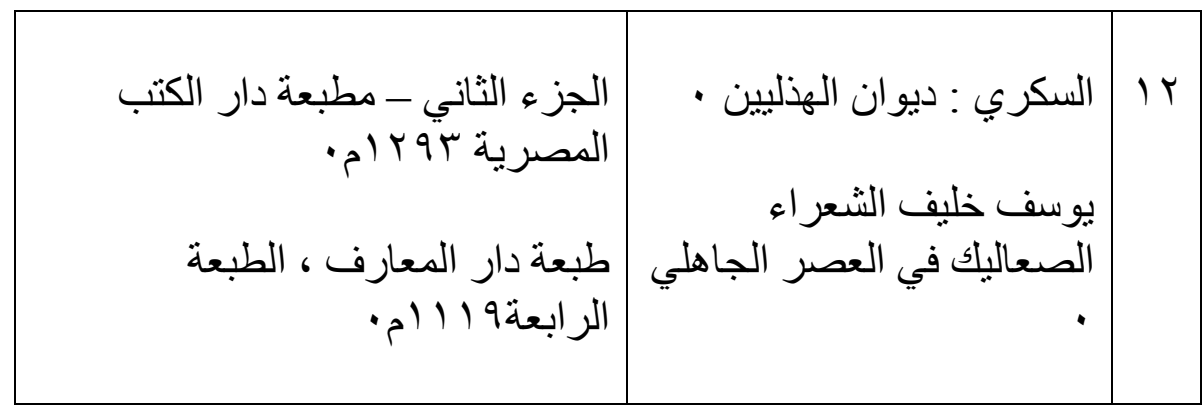




\section{فهرس الموضوعات}

Yง

المقدمة

\section{المبحث الأول :}

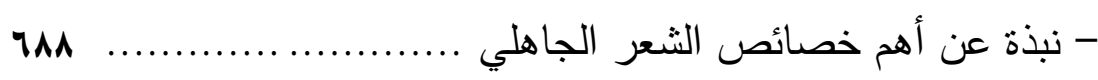

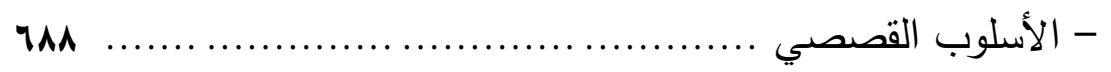

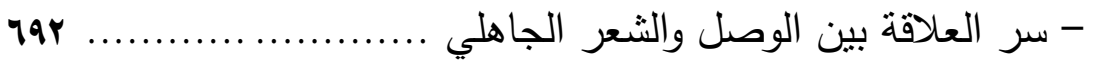

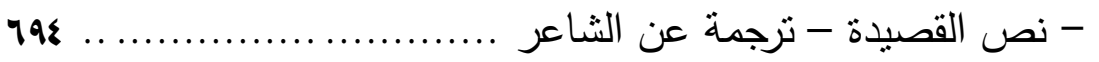

\section{المبحث الثاذي :}

791 - التحليل البلاغي للقصيدة . VOA

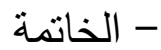
v.. - المصادر والمراجع vyr الثهرس 